Prepared in cooperation with the San Antonio Water System

\title{
Updated Numerical Model with Uncertainty Assessment of 1950-56 Drought Conditions on Brackish-Water Movement within the Edwards Aquifer, San Antonio, Texas
}

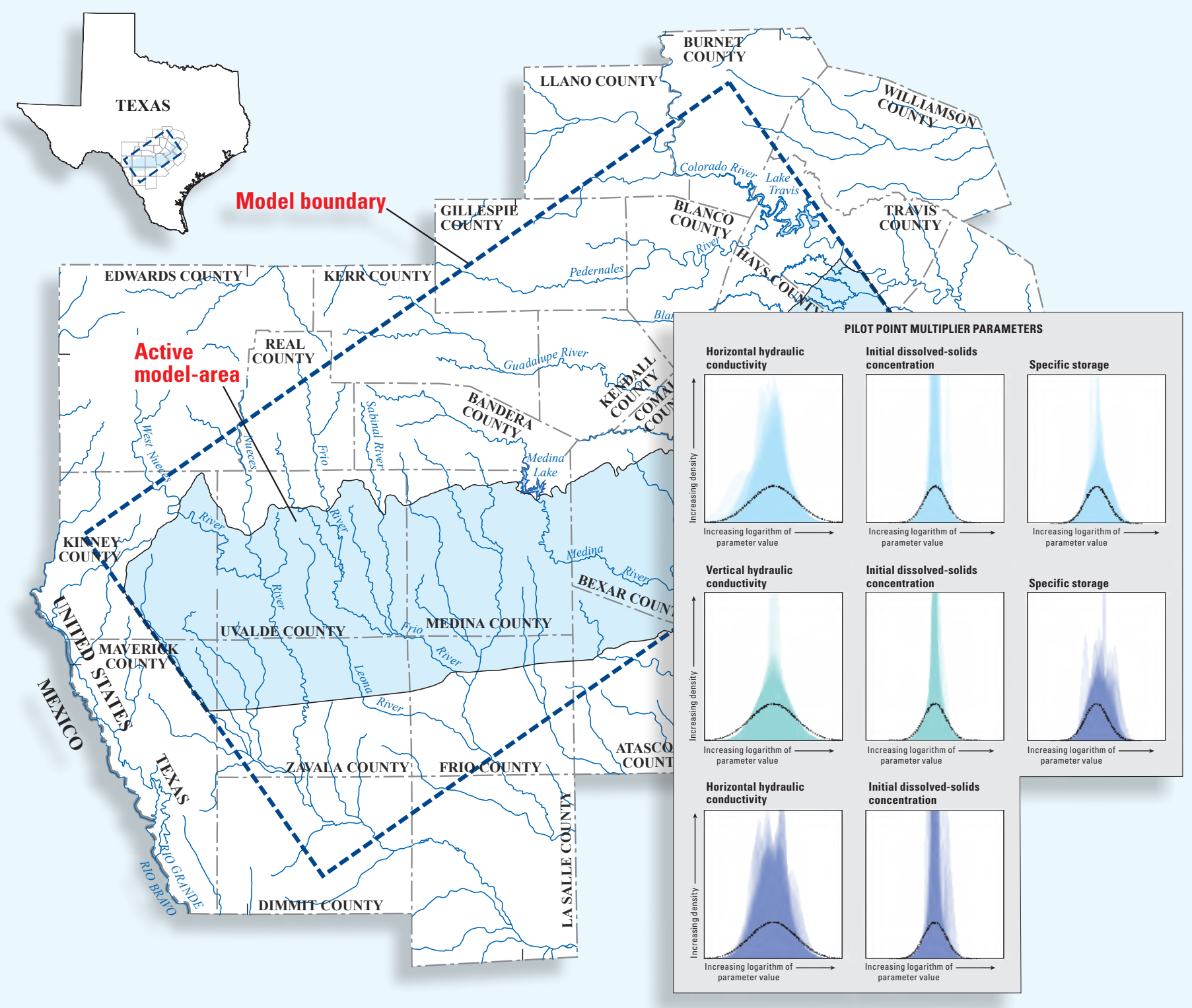

Scientific Investigations Report 2015-5081

U.S. Department of the Interior

U.S. Geological Survey 
Cover illustration: modified versions of figures 1 and 22. 


\section{Updated Numerical Model with Uncertainty Assessment of 1950-56 Drought Conditions on Brackish-Water Movement within the Edwards Aquifer, San Antonio, Texas}

By Linzy K. Brakefield, Jeremy T. White, Natalie A. Houston, and Jonathan V. Thomas

Prepared in cooperation with the San Antonio Water System

Scientific Investigations Report 2015-5081 


\title{
U.S. Department of the Interior SALLY JEWELL, Secretary
}

\section{U.S. Geological Survey \\ Suzette M. Kimball, Acting Director}

\author{
U.S. Geological Survey, Reston, Virginia: 2015
}

For more information on the USGS - the Federal source for science about the Earth, its natural and living resources, natural hazards, and the environment—visit http://www.usgs.gov or call 1-888-ASK-USGS.

For an overview of USGS information products, including maps, imagery, and publications, visit http://www.usgs.gov/pubprod/.

Any use of trade, firm, or product names is for descriptive purposes only and does not imply endorsement by the U.S. Government.

Although this information product, for the most part, is in the public domain, it also may contain copyrighted materials as noted in the text. Permission to reproduce copyrighted items must be secured from the copyright owner.

Suggested citation:

Brakefield, L.K., White, J.T., Houston, N.A., and Thomas, J.V., 2015, Updated numerical model with uncertainty assessment of 1950-56 drought conditions on brackish-water movement within the Edwards aquifer, San Antonio, Texas: U.S. Geological Survey Scientific Investigations Report 2015-5081, 54 p., http://dx.doi.org/10.3133/ sir20155081.

ISSN 2328-0328 (online) 


\section{Acknowledgments}

The authors thank Richard Lindgren (U.S. Geological Survey, retired) for his insight and knowledge of previously developed MODFLOW models of the Edwards aquifer and his willingness to provide assistance. 


\section{Contents}

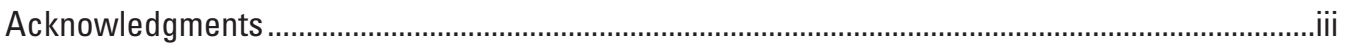

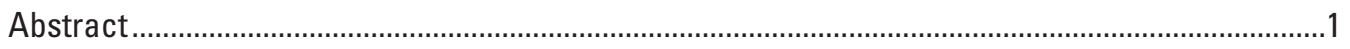

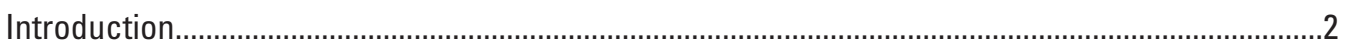

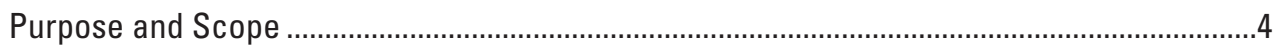

Background and Previous Investigations..........................................................................

Updated Conceptualization and Numerical Model of the Edwards Aquifer.....................................5

Updated Conceptualization of Hydrogeology for Numerical Model ...........................................

Review of Groundwater-Flow System .................................................................................

Water-Quality Zones..................................................................................................

Aquifer Hydraulic and Transport Properties ...................................................................

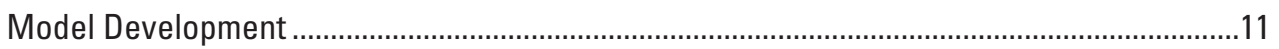

History-Matching Phase ........................................................................................................ 11

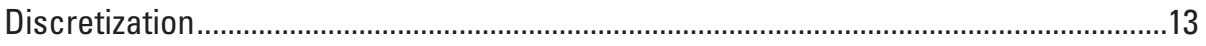

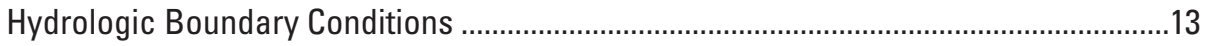

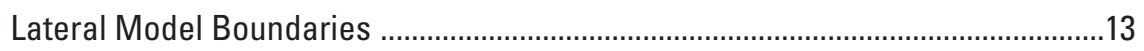

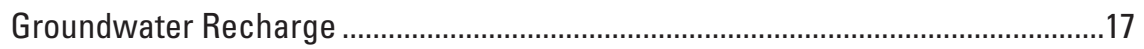

Groundwater Discharge ...................................................................................17

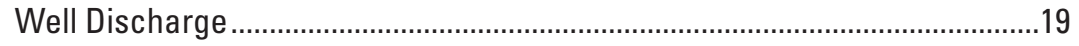

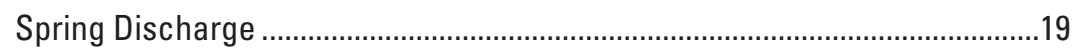

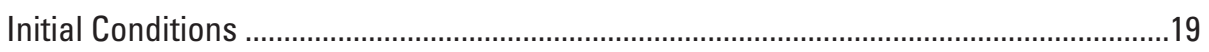

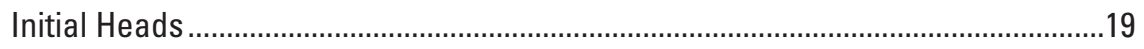

Initial Dissolved-Solids Concentrations ..............................................................19

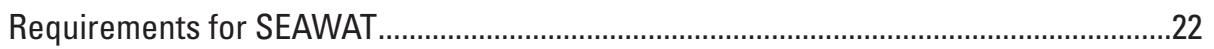

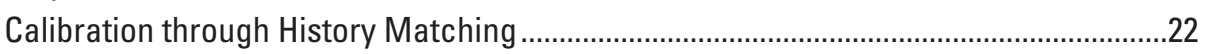

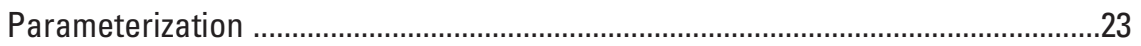

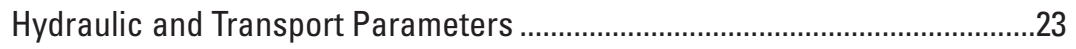

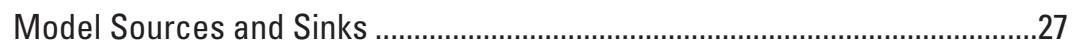

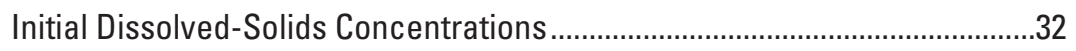

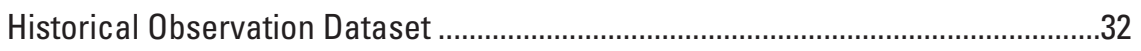

Groundwater Head Observations ...............................................................35

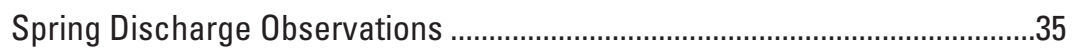

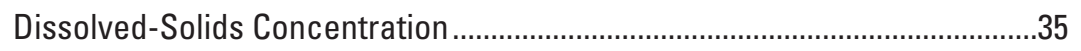

Constraints on Total Mass of Dissolved Solids at Production Wells ...............35

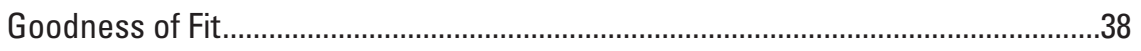

Parameter Uncertainty—Schur's Complement for Linear-Based Conditional Uncertainty

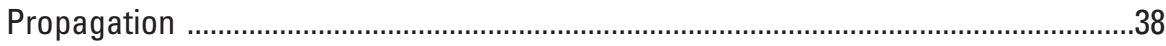

Uncertainty Assessment of 1950-56 Drought Conditions on Brackish-Water Movement within

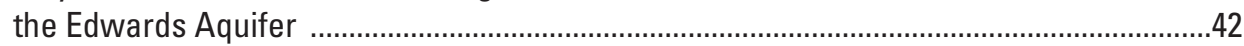

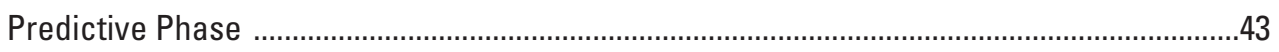

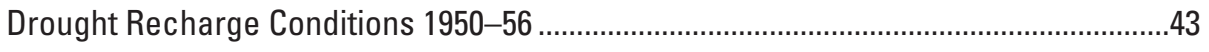

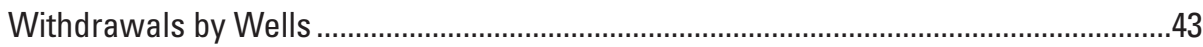


Prediction Uncertainty—Schur's Complement for Linear-Based Conditional Uncertainty

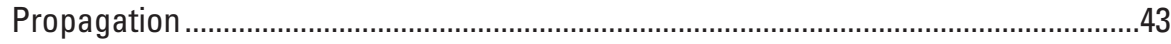

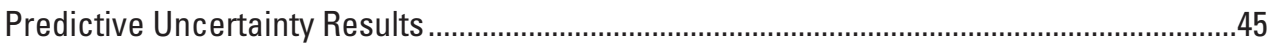

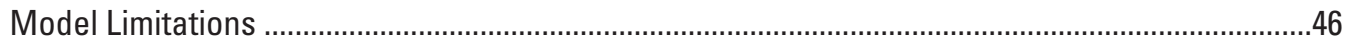

Summary

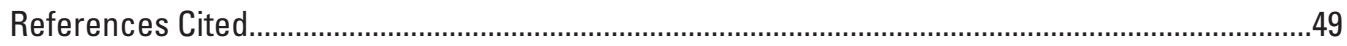

\section{Figures}

1 Map showing location of model area, Edwards aquifer segments, depositional provinces, groundwater divides, and physiographic regions, San Antonio region, Texas.

2. Diagrammatic northwest-to-southeast section showing hydrogeologic framework and generalized groundwater-flow directions, San Antonio region, Texas .....................6

3. Graph showing correlation of Cretaceous stratigraphic units and hydrogeologic units, relative permeability and model layers in the Edwards aquifer model area, San Antonio region, Texas

4. Map showing recharge, freshwater, brackish-water transition, and saline zones of the Edwards aquifer, San Antonio region, Texas.....

5. Map showing active model area and boundary conditions, San Antonio region, Texas.

6. Maps showing faults and altitude of top of Edwards aquifer active model area, and thickness of Edwards aquifer active model area, San Antonio region, Texas .........14

7. Maps showing altitude of top, and thickness of the middle part of the Edwards aquifer (model layer 4), San Antonio region, Texas

8. Map showing number of active model layers per cell, San Antonio region, Texas........16

9. Map showing lines of equal dissolved-solids concentrations, dissolved-solids concentration locations of measured or estimated values based on data collected from 1930 through 2009, and distribution of interpolated dissolved-solids concentrations, San Antonio region, Texas..

10. Map showing average annual groundwater withdrawals during 1999-2009, and the production wells of predictive interest near the brackish-water transition zone, San Antonio region, Texas

11. Map showing locations of pilot points where hydraulic properties are adjusted during history matching, San Antonio region, Texas.....

12. Maps showing the history-matched best-fit distributions of hydraulic conductivities of the Edwards aquifer, San Antonio region, Texas. Horizontal hydraulic conductivity of the upper part of the Edwards aquifer. Vertical hydraulic conductivity of the middle part of the Edwards aquifer. Horizontal hydraulic conductivity of the lower part of the Edwards aquifer......

13. Maps showing the history-matched best-fit distributions of specific storage of the Edwards aquifer, San Antonio region, Texas for the upper part of the Edwards aquifer, and the lower part of the Edwards aquifer .....

14. Maps showing the history-matched best-fit distributions of effective porosity of the Edwards aquifer, San Antonio region, Texas for the upper part of the Edwards aquifer, and the lower part of the Edwards aquifer 
15. Map showing the history-matched best-fit distributions of recharge multipliers for the surface-water basins overlying the Edwards aquifer, San Antonio region, Texas. Recharge multipliers for the wetter months of April-June, September-November. Recharge multipliers for the drier months of January-March, July, August, and December

16. Graph showing the history-matched best-fit annual recharge multipliers, 1999-2009

17. Maps showing inflow of groundwater from the Trinity aquifer (flux) into the overlying Edwards aquifer, San Antonio region, Texas. Initial flux. History-matched bestfit flux

18. Maps showing the history-matched best-fit distributions of initial dissolved-solids concentrations of the Edwards aquifer, San Antonio region, Texas for the upper part of the Edwards aquifer, the middle part of the Edwards aquifer, and the lower part of the Edwards aquifer.

19. Map showing locations of observation data used for history matching (groundwater withdrawals, springs, dissolved-solids concentrations, and groundwater heads), San Antonio region, Texas, 1999-2009.

20. Graphs showing observed values compared to simulated values and residuals for groundwater heads, spring discharges, and dissolved-solids concentrations, San Antonio region, Texas.

21. Graphs showing simulated and observed time-series of Comal Springs discharge, San Marcos Springs discharge, and Bexar County index well J-17 groundwater head, San Antonio region, Texas

22. Graphs showing distributions of prior (before history matching) and posterior (after history matching) parameter uncertainty

23. Graphs showing groundwater flows (fluxes) and cumulative volumes for the historymatched model (1999-2009) and the predictive model (1950-56), San Antonio region, Texas. Positive values represent groundwater gains, and negative values represent groundwater losses

24. Graph showing the upper bound of the 95-percent credible interval for the prior and posterior predictive uncertainty of dissolved-solids concentration change during the $1950-56$ predictive model period at production wells of interest.

\section{Tables}

1. The history-matched best-fit Drain (DRN) package altitude and conductance parameters that control spring discharge from the model, San Antonio region, Texas 


\section{Conversion Factors}

Inch/Pound to International System of Units

\begin{tabular}{|c|c|c|}
\hline Multiply & By & To obtain \\
\hline \multicolumn{3}{|c|}{ Length } \\
\hline foot $(\mathrm{ft})$ & 0.3048 & meter $(\mathrm{m})$ \\
\hline mile (mi) & 1.609 & kilometer (km) \\
\hline \multicolumn{3}{|c|}{ Volume } \\
\hline cubic foot $\left(\mathrm{ft}^{3}\right)$ & 0.02832 & cubic meter $\left(\mathrm{m}^{3}\right)$ \\
\hline acre-foot (acre-ft) & 1,233 & cubic meter $\left(\mathrm{m}^{3}\right)$ \\
\hline \multicolumn{3}{|c|}{ Flow rate } \\
\hline acre-foot per year (acre-ft/yr) & 1,233 & cubic meter per year $\left(\mathrm{m}^{3} / \mathrm{yr}\right)$ \\
\hline cubic foot per day $\left(\mathrm{ft}^{3} / \mathrm{d}\right)$ & 0.02832 & cubic meter per day $\left(\mathrm{m}^{3} / \mathrm{d}\right)$ \\
\hline \multicolumn{3}{|c|}{ Density } \\
\hline pound per cubic foot $\left(\mathrm{lb} / \mathrm{ft}^{3}\right)$ & 16.02 & kilogram per cubic meter $\left(\mathrm{kg} / \mathrm{m}^{3}\right)$ \\
\hline \multicolumn{3}{|c|}{ Hydraulic conductivity } \\
\hline foot per day (ft/d) & 0.3048 & meter per day $(\mathrm{m} / \mathrm{d})$ \\
\hline \multicolumn{3}{|c|}{ DRN (Drain Package) conductance } \\
\hline foot squared per day $\left(\mathrm{ft}^{2} / \mathrm{d}\right)$ & 0.09290 & meter squared per day $\left(\mathrm{m}^{2} / \mathrm{d}\right)$ \\
\hline
\end{tabular}

\section{Supplemental Information}

Specific conductance is given in microsiemens per centimeter at 25 degrees Celsius $(\mu \mathrm{S} / \mathrm{cm}$ at $\left.25^{\circ} \mathrm{C}\right)$.

Concentrations of chemical constituents in water are given in milligrams per liter (mg/L).

\section{Datums}

Vertical coordinate information is referenced to the National Geodetic Vertical Datum of 1929 (NGVD 29).

Horizontal coordinate information is referenced to the North American Datum of 1983 (NAD 83).

Altitude, as used in this report, refers to distance above the vertical datum. 


\section{Abbreviations}

$\begin{array}{ll}\text { BTN } & \text { Basic Transport Package (in MT3DMS) } \\ \text { DRN } & \text { Drain Package (in MODFLOW) } \\ \text { EAA } & \text { Edwards Aquifer Authority } \\ \text { GIS } & \text { geographic information system } \\ \text { HFB } & \text { Horizontal-Flow Barrier Package (in MODFLOW) } \\ \text { MODFLOW } & \text { A modular three-dimensional finite-difference ground-water flow model } \\ \text { MT3DMS } & \text { Modular 3-D multi-species transport model for simulation of advection, } \\ & \text { dispersion, and chemical reactions of contaminants in groundwater systems } \\ \text { MUD } & \text { Fort Clark Municipal Utility District } \\ \text { NWIS } & \text { National Water Information System } \\ \text { PEST } & \text { Model-independent Parameter ESTimation code } \\ \text { RCH } & \text { Recharge Package (in MODFLOW) } \\ \text { RDM } & \text { regional dense member } \\ \text { SAWS } & \text { San Antonio Water System } \\ \text { SEAWAT } & \text { A computer program for simulation of three-dimensional variable-density } \\ & \text { groundwater flow } \\ \text { SP } & \text { spontaneous potential } \\ \text { SSM } & \text { Source/Sink Mixing Package (in MT3DMS) } \\ \text { SSP } & \text { static self-potential } \\ \text { TCEO } & \text { Texas Commission on Environmental Quality } \\ \text { TWDB } & \text { Texas Water Development Board } \\ \text { USGS } & \text { U.S. Geological Survey } \\ \text { WEL } & \text { Well Package (in MODFLW) } \\ & \end{array}$




\title{
Updated Numerical Model with Uncertainty Assessment of 1950-56 Drought Conditions on Brackish-Water Movement within the Edwards Aquifer, San Antonio, Texas
}

\author{
By Linzy K. Brakefield, Jeremy T. White, Natalie A. Houston, and Jonathan V. Thomas
}

\section{Abstract}

In 2010, the U.S. Geological Survey, in cooperation with the San Antonio Water System, began a study to assess the brackish-water movement within the Edwards aquifer (more specifically the potential for brackish-water encroachment into wells near the interface between the freshwater and brackishwater transition zones, referred to in this report as the transition-zone interface) and effects on spring discharge at Comal and San Marcos Springs under drought conditions using a numerical model. The quantitative targets of this study are to predict the effects of higher-than-average groundwater withdrawals from wells and drought-of-record rainfall conditions of 1950-56 on (1) dissolved-solids concentration changes at production wells near the transition-zone interface, (2) total spring discharge at Comal and San Marcos Springs, and (3) the groundwater head (head) at Bexar County index well J-17. The predictions of interest, and the parameters implemented into the model, were evaluated to quantify their uncertainty so the results of the predictions could be presented in terms of a 95-percent credible interval.

The model area covers the San Antonio and Barton Springs segments of the Edwards aquifer; the history-matching effort was focused on the San Antonio segment. A previously developed diffuse-flow model of the Edwards aquifer, which forms the basis for the model in this assessment, is primarily based on a conceptualization in which flow in the aquifer is predominately through a network of numerous small fractures and openings. Primary updates to this model include an extension of the active area downdip, a conversion to an 8-layer SEAWAT variable-density flow and transport model to simulate dissolved-solids concentration effects on water density, history matching to 1999-2009 conditions, and parameter estimation in a highly parameterized context using automated methods in PEST (a model-independent Parameter ESTimation code).

In addition to the best-fit parameter values derived from history matching, the uncertainty of model parameters was also estimated by using linear uncertainty analysis. Comparison of "prior" (before history matching) and "posterior" (after history matching) variances of parameters indicate that the information within the observation dataset used for history matching informs many parameters. The concentration threshold parameters were well-informed by the observation dataset as their posterior distributions were much narrower than their prior distributions. The transition-zone scaling parameters of hydraulic conductivity, effective porosity, and specific storage were all informed by the observation dataset, as evidenced by the difference between the prior and posterior variances. Saline-zone scaling parameters, alternatively, were not informed by the observation dataset for effective porosity and specific storage. Resulting posterior drier-month, wettermonth, and annual recharge multiplier parameter variances are important to understanding how well recharge is estimated and implemented within the model. The shifts of the posterior distributions left and right indicate that there were zones where less or more water was needed in the model. The widths of the distributions were not decreased substantially, indicating that many of the best-fit recharge parameters are not statistically different from the initial values specified in the history-matching effort. Recharge from rainfall is the driving force behind groundwater flow and heads in the aquifer; therefore, an increase in understanding of this process would benefit model development by potentially decreasing the uncertainty of this parameter. The history-matching effort was most helpful in informing the parameters in the model that control discharge at springs, namely, the spring orifice (drain) altitude and drain conductance parameters for each spring.

The uncertainty assessment of the predictive model (a hypothetical recurrence of 1950-56 drought conditions and higher-than-average groundwater withdrawals from wells) provided insights into the potential effects of these conditions on dissolved-solids concentration changes at production wells near the transition-zone interface, discharges at Comal and San Marcos Springs, and heads at Bexar County index well J-17. Results at the 25 production wells near the transition-zone 
interface indicate that the uncertainty of model input parameters based on expert knowledge yielded an upper bound of the 95-percent credible interval of dissolved-solids concentrations that exceeds the secondary drinking water standards of 1,000 milligrams per liter $(\mathrm{mg} / \mathrm{L})$ of the Texas Commission on Environmental Quality (TCEQ) for many wells. However, the history-matching process provided key information to inform prediction-sensitive model parameters and therefore, contributed to a substantial decrease of the upper bound of the 95-percent credible interval to below the secondary drinking water standards. Reductions in dissolved-solids concentration changes were on the order of $400 \mathrm{mg} / \mathrm{L}$ to $1,300 \mathrm{mg} / \mathrm{L}$. The reduction in uncertainty in regards to this prediction implies that this prediction of dissolved-solids concentration change can be made with some certainty using this current model and that those parameters that control this prediction are informed by the observation dataset. Even though predictive uncertainty was reduced for this prediction, dissolved-solids concentration changes were still greater than zero, indicating a minimal increase in concentration at these 25 production wells during the 7-year simulation period is likely. However, this minimal concentration increase indicates a small potential for movement of the brackish-water transition zone near these wells during the 7-year simulation period of drought-ofrecord (1950-56) rainfall conditions with higher-than-average groundwater withdrawals by wells.

Predictive results of total spring discharge during the 7-year period, as well as head predictions at Bexar County index well J-17, were much different than the dissolved-solids concentration change results at the production wells. These upper bounds are an order of magnitude larger than the actual prediction which implies that (1) the predictions of total spring discharge at Comal and San Marcos Springs and head at Bexar County index well J-17 made with this model are not reliable, and (2) parameters that control these predictions are not informed well by the observation dataset during historymatching, even though the history-matching process yielded parameters to reproduce spring discharges and heads at these locations during the history-matching period. Furthermore, because spring discharges at these two springs and heads at Bexar County index well J-17 represent more of a cumulative effect of upstream conditions over a larger distance (and longer time), many more parameters (with their own uncertainties) are potentially controlling these predictions than the prediction of dissolved-solids concentration change at the prediction wells, and therefore contributing to a large posterior uncertainty.

\section{Introduction}

The Edwards aquifer is one of the most prolific aquifers in the world and supplies water to users in several counties in south-central Texas (Maclay, 1995). The largest municipality that uses the Edwards aquifer for water supply is San Antonio, Tex., the seventh most populous city in the U.S. (U.S. Census Bureau, 2014). Residents in south-central Texas rely on water from the Edwards aquifer for residential, recreational, industrial, and agricultural uses (Lindgren and others, 2004). In the San Antonio and Austin areas, the Edwards aquifer was deemed a sole-source aquifer by the U.S. Environmental Protection Agency (1975, 1988, and 2015), and several endangered and threatened species are sustained by groundwater discharged at Comal, San Marcos, and Barton Springs (fig. 1).

The Edwards aquifer consists of regionally extensive carbonate rocks that dip from the outcrop region within the Edwards Plateau and the Balcones fault zone toward the south and southeast beneath the Gulf Coastal Plain (fig. 1). The southernmost extent of the freshwater zone of the Edwards aquifer is defined by a dissolved-solids concentration of 1,000 milligrams per liter $(\mathrm{mg} / \mathrm{L})$, a concentration that serves as the interface between the freshwater zone of the aquifer and the brackish-water transition zone that consists of water with dissolved-solids concentrations ranging from 1,000 to $10,000 \mathrm{mg} / \mathrm{L}$. The brackish-water transition zone discussed in this report has been referred to as the freshwater/saline-water transition zone in other reports (Lambert and others, 2010; Thomas and others, 2012). The dissolved-solids concentrations of 1,000 to $10,000 \mathrm{mg} / \mathrm{L}$ are within the range termed "brackish" by Freeze and Cherry (1979). In this report, the interface between the freshwater and brackish-water transition zones is referred to as the transition-zone interface, and the brackish-water transition zone is referred to as the transition zone. The part of the Edwards aquifer downdip of the transition zone is referred to as the saline zone, which is characterized by water with dissolved-solids concentrations in excess of $10,000 \mathrm{mg} / \mathrm{L}$.

Because the Edwards aquifer is an important water resource for the area, there are concerns about a repeat, or exceedance of, the drought-of-record (1950-56) conditions. Recent (1999-2009) groundwater withdrawal rates in the Edwards aquifer are much greater than they were during the 1950s (Lindgren and others, 2004) and could potentially cause movement of the transition zone, cause production wells to draw nonpotable water, or result in sustained reductions in spring discharges from Comal and San Marcos Springs (fig. 1). Since 2011, drought conditions have existed in southcentral Texas (Texas Water Development Board, 2014), further underscoring the need to better understand drought effects on potential brackish-water movement, groundwater levels (heads), and spring discharges.

Many studies have characterized the transition zone to better understand this zone between the freshwater and saline water zones of the Edwards aquifer (for example, Garza, 1962; Groschen, 1994; Groschen and Buszka, 1997; Pavlicek and others, 1987; Perez, 1986; Schultz, 1992; Schultz, 1993; Schultz, 1994). Several wells constructed in transects across the transition zone have been the subject of studies by the U.S. Geological Survey (USGS) in cooperation with the 


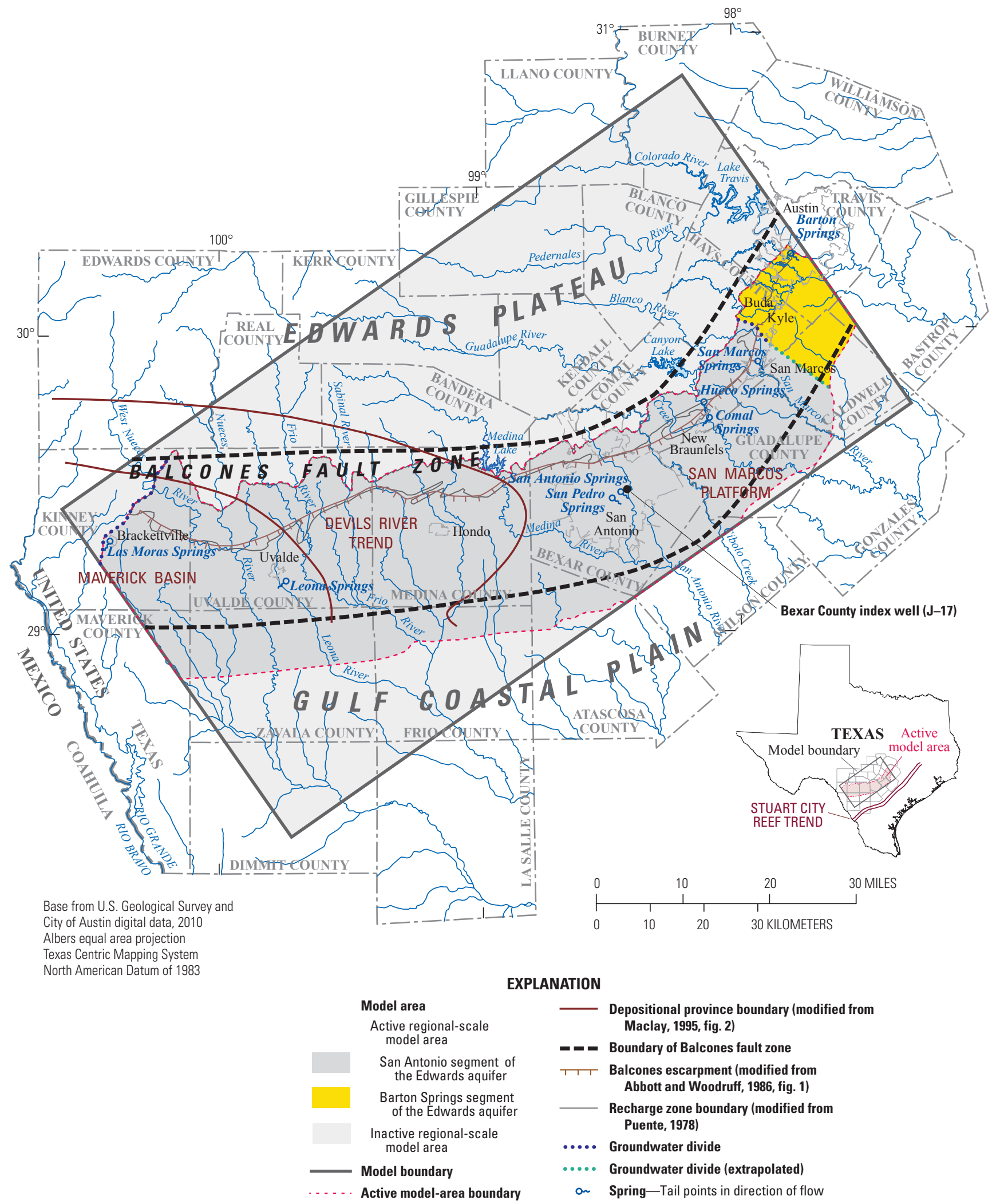

Figure 1 Location of model area, Edwards aquifer segments, depositional provinces, groundwater divides, and physiographic regions, San Antonio region, Texas (modified from Lindgren and others [2011a, fig. 1]). 
Updated Numerical Model with Uncertainty Assessment of 1950-56 Drought Conditions on Brackish-Water Movement

San Antonio Water System (SAWS). The objectives of these studies have included gaining a better understanding of the hydraulic dynamics between the freshwater and transition zones, and insights into the structure and properties of the aquifer in the transition zone at the local scale (Lambert and others, 2009; Lambert and others, 2010; Thomas and others, 2012).

In 2010, the USGS, in cooperation with SAWS, began a study to assess the brackish-water movement within the Edwards aquifer (more specifically the potential for brackish-water encroachment into wells near the transition-zone interface) and effects on discharge at Comal and San Marcos Springs under drought conditions using a numerical model. Twenty-five production wells near the transition-zone interface were selected to evaluate encroachment of brackish water updip from the transition zone into the freshwater zone. Discharges at Comal and San Marcos Springs are a concern because of the potential ecological effects on riparian habitat that sustains several endangered species; the vitality of the riparian habitat is dependent upon flows from these springs. Groundwater heads (heads) at the Bexar County index well J-17 (hereinafter referred to as "well J-17") are an indicator of groundwater availability in the Edwards aquifer; heads at this well have been measured since 1932 (Edwards Aquifer Authority, 2015) and a statistical correlation between heads at this well and discharge at Comal Springs has been established (Miller and Long, 2006). Therefore, it was also of interest to determine effects from drought conditions on heads at this monitoring well.

\section{Purpose and Scope}

This report describes a variable-density groundwater flow and transport numerical model constructed by using the computer program SEAWAT version 4. Modeling was completed in two phases: the history-matching phase and the predictive phase. In addition to modeling, an uncertainty assessment was done to quantify the combined effects of rainfall amounts identical to those of the drought of record (1950-56) and recent (1999-2009) groundwater withdrawals from the Edwards aquifer on the potential movement of the transition zone in the San Antonio segment of the Edwards aquifer, potential effects on discharge at Comal and San Marcos Springs, and potential effects on heads at well J-17. The model that was developed is an updated numerical model of the San Antonio and Barton Springs segments of the Edwards aquifer that was based on the diffuse-flow model of Lindgren (2006). Major updates to this model, as described in this report in the history-matching phase, include simulation of the Edwards aquifer farther downdip than in previous models, the addition of more model layers to better represent aquifer heterogeneities and anisotropy, and an updated simulation (1999-2009) for history matching. The model was history matched in a highly parameterized context using PEST, a model-independent Parameter ESTimation code that allows for model calibration, parameter estimation, and calculation of parameter and predictive uncertainties (Doherty, 2005; Doherty and Hunt, 2010; Doherty and others, 2010b). The focus of the predictive model created in the predictive phase (hypothetical scenario of drought-of-record rainfall combined with recent groundwater withdrawals), and therefore the history-matching effort, was on the freshwater and transition zones of the confined part of the San Antonio segment of the Edwards aquifer (fig. 1). Linear uncertainty analysis was completed by using PEST to quantify the uncertainty of model parameters and predictions. The uncertainty assessment focused on (1) dissolved-solids concentrations changes in target production wells near the transition-zone interface, (2) spring discharge at Comal and San Marcos Springs, and (3) heads at well J-17.

\section{Background and Previous Investigations}

Several numerical groundwater-flow models have been constructed for the San Antonio and Barton Springs segments of the Edwards aquifer. Lindgren and others (2009) described and evaluated six regional-scale groundwater-flow models. One model discussed in Lindgren and others (2009) was the one-layer (vertically averaged) diffuse-flow model (Lindgren, 2006). This model forms the basis of the model developed in this study. The diffuse-flow model is based primarily on the conceptualization in which water in the aquifer flows predominantly through a network of numerous small fractures and openings. The diffuse-flow model, as well as the previous one-layer conduit-flow model (Lindgren and others, 2004), were modified by Lindgren and others (2011b) to have a finer horizontal discretization, an additional second layer, and to simulate conditions of 2001-2003. The focus of the previous MODFLOW modeling efforts were to calibrate these models to steady-state and transient periods to better understand groundwater budgets, regional flow, and transmissivity and storativity distributions. A local-scale MODFLOW model was also developed to investigate the contributing zone to a public supply well in San Antonio (Lindgren and others, 2011a) using particle-tracking. All of these models assume a uniform, freshwater density for the Edwards aquifer, that extends to the southern boundary (approximated at the 10,000-mg/L contour of equal dissolved-solids concentration [hereinafter referred to as the "10,000-mg/L dissolved-solids contour"]), and do not account for variable-density conditions that exist in the aquifer. Furthermore, the regional-scale models are vertically simplified representations of the complex anisotropic and heterogeneous sloping aquifer. The only previously published model simulating potential transition-zone encroachment is a one-dimensional solute-transport model (Perez, 1986). Results from the simulations and sensitivity analysis completed by Perez indicated that to accurately simulate encroachment of saline water into the freshwater zone, more information was 
needed to characterize groundwater heads, transmissivity, porosity, and dispersivity in the transition zone separating the freshwater and saline water zones. Since the one-dimensional simplified model of Perez (1986), improved modeling tools, increased computational power, additional data, and more scientific knowledge exist, allowing for more rigorous simulation of variable-density flow in the freshwater and transition zones.

Several field-based assessments have been completed to better characterize the transition zone by using water-level (head), lithologic, temperature, and geophysical log data collected at wells that traverse the transition zone (transect wells) (Lambert and others, 2010; Lambert and others, 2009; Thomas and others, 2012). Analysis of equivalent freshwater-head gradients at these transect wells indicate that, although some potential for flow between the freshwater and transition zones exists, this potential is highly variable across the region. Furthermore, the transition zone is stable laterally and vertically and in time, and is likely to remain stable (Lambert and others, 2010). A previous local-scale field investigation by Groschen (1994) was focused on gaining a better understanding of the hydrology of the aquifer near the downdip extent of freshwater and also was focused on gaining a better understanding of the evolution of water chemistry. Groschen (1994) also presented a thorough literature review of current understanding of the transition zone and a summary about saline-zone groundwater flow and geochemical alteration of the aquifer from freshwater flows and dedolomitization [the dissolution of dolomite and net precipitation of calcite (Deike, 1990)] through time.

Contours of dissolved-solids concentrations in the Edwards aquifer (Schultz 1992, 1993, 1994; A.L. Schultz, private consultant, written commun., 2000) were mapped (two dimensions) based on geophysical-log estimates of dissolvedsolids concentrations and water-quality data. To date, this map is the most widely accepted understanding of the complicated three-dimensional distribution of dissolved solids in the Edwards aquifer, although the map contours are a two-dimensional interpretation and do not depict changes in dissolved solids at depth. The mapped 10,000-mg/L dissolved-solids contour (A.L. Schultz, private consultant, written commun., 2000) has been used as the southern boundary in models simulating freshwater flows (Lindgren and others, 2004; Lindgren, 2006, Lindgren and others, 2011b).

Groschen and Buszka (1997) focused on geochemical characterization of the saline zone of the Edwards aquifer. The primary findings based on geochemical and isotope analysis were that water of the saline zone can be separated into two distinct hydrological and geochemical regimes: the shallower regime is mostly meteoric water that has been recharged within recent geologic time and the deeper regime is hydrologically stagnant when compared to the updip regime. These two regimes exist, in part, because faults function as barriers to downdip flow of recharge water and likely, to updip flow of saline water (Groschen and Buszka, 1997).

\section{Updated Conceptualization and Numerical Model of the Edwards Aquifer}

The conceptualization of the Edwards aquifer and implementation of this conceptualization into a numerical model was based on previous modeling efforts (Lindgren and others, 2004; Lindgren, 2006; Lindgren and others, 2011b). In previous USGS models, the Edwards aquifer was simulated on a regional scale by using a model with a single layer (Lindgren and others, 2004; Lindgren, 2006) or a model with two layers (Lindgren and others, 2011b). Previous models simulated a freshwater zone and brackish-water zone of groundwater containing as much as $10,000 \mathrm{mg} / \mathrm{L}$ of dissolved solids, although a uniform freshwater density was assumed throughout the model domain (Lindgren and others, 2004; Lindgren, 2006; Lindgren and others, 2011b). Because variations in density can potentially affect groundwater flows, the uniform freshwater-density diffuse-flow model (Lindgren, 2006) was converted into an eight-layer coupled variable-density flow and transport model. The USGS's SEAWAT version 4 computer program (Langevin and others, 2008) was used to develop the updated model. This updated conceptualization and model implementation was completed to include a larger active downdip extent of the model, include simulation of density-driven flow and transport processes (specifically dissolved-solids concentration effects on density) and to better represent the vertical and horizontal anisotropy and heterogeneity of the aquifer.

Uncertainty in the parameters implemented into the model and the model predictions of interest were quantified by using a linear uncertainty analysis approach (Doherty and others, 2010b) with 95-percent credible intervals. The linear uncertainty analysis used in this assessment is based on Bayes' equation (Doherty and others, 2010b). The uncertainty analysis yields estimates of credible intervals instead of the more common confidence intervals (used in frequentist statistics). Gelman and others (2014, p. 3) explain that a credible interval (also known as Bayesian interval or Bayesian probability interval) "for an unknown quantity of interest can be directly regarded as having a high-probability of containing the unknown quantity, in contrast to a frequentist (confidence) interval, which may strictly be interpreted only in relation to a sequence of similar inferences that may be made in repeated practice." In this study, the term Gaussian distribution is a probability density function and the uncertainty is measured through estimation of 95-percent credible intervals. The prior is a multivariate Gaussian distribution that describes parameter uncertainty defined solely on the basis of the innate variability of parameters (Doherty and others, 2010b). The prior must be quantified by the modeler (Doherty and others, 2010b) based on their expert knowledge of the system (Doherty, 2005; Fienen and others, 2013). The posterior is a multivariate Gaussian distribution, which combines the prior 
with information contained in the observation dataset used for history matching. History matching is often referred to as model calibration, but the term history matching has been used extensively in reservoir modeling in the petroleum industry (Oliver and others, 2008) and is chosen for this report because it more "clearly conveys the essence of the modeling process than does the term calibration (Konikow and Bredehoeft, 1992)." Gelman describes the posterior as the "conditional probability distribution of the unobserved quantities of ultimate interest, given the observed data" (Gelman and others, 2014). Model parameters and predictions of interest given as credible intervals, rather than one estimate derived from the "best fit" of the model parameters to the data, where "best fit" refers to the minimum of the weighted least-squares objective function, are more defensible and more meaningful. Furthermore, uncertainty estimates (credible intervals) are indicative of a model's reliability in making a prediction (Refsgaard and others, 2007).

\section{Updated Conceptualization of Hydrogeology for Numerical Model}

Details on the geology and hydrogeologic setting of the freshwater extent have been extensively discussed in several modeling and geology reports (Lindgren and others, 2004; Lindgren, 2006; Maclay, 1995; Rose, 1972). Lower Cretaceous limestone and dolomite compose the karstic Edwards aquifer (Hovorka and others, 1996; Rose, 1972), which extends downdip of the freshwater zone within the Balcones Fault Zone to the Stuart City Reef Trend (fig. 1) (Groschen and Buszka, 1997; Oetting and others, 1996; Waite, 2008) at depths greater than 10,000 feet below the National Geodetic Vertical Datum of 1929 (Rose, 1972). The unconfined outcrop of the Edwards aquifer in the northern part of the study area is the recharge zone (figs. 1-2). South and southeast of the outcrop, the aquifer becomes confined and is overlain by younger, lower-permeability rocks (figs. 1-2).

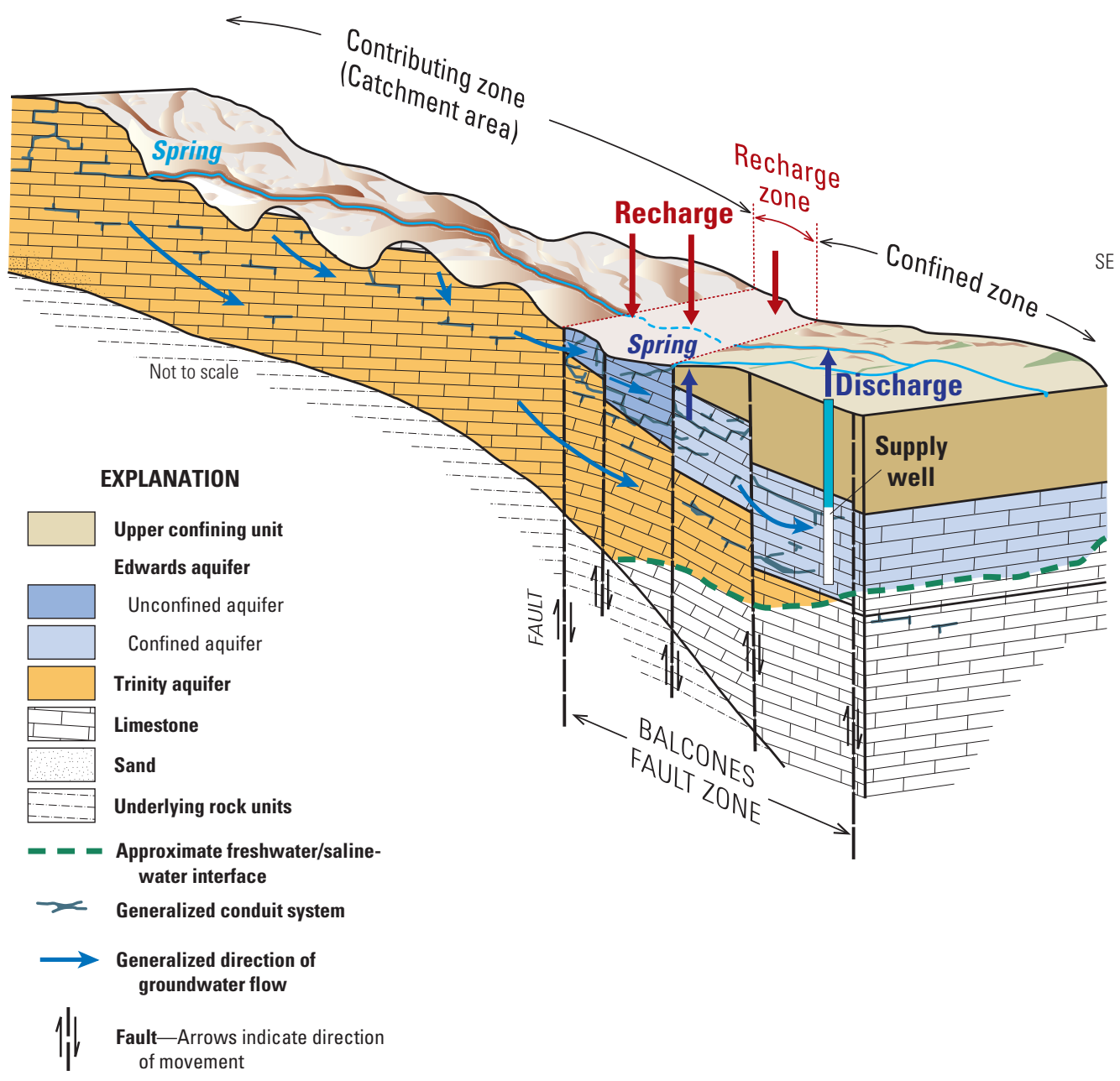

Figure 2. Diagrammatic northwest-to-southeast section showing hydrogeologic framework and generalized groundwater-flow directions, San Antonio region, Texas (modified from Barker and Ardis, 1996, plates 1 and 3). 
The Edwards aquifer is characterized by three different depositional provinces (figs. 1 and 3): the San Marcos Platform in the eastern part of the study area, the Maverick Basin in the western part, and the Devils River Trend in the west-central part (Lozo and Smith, 1964; Maclay, 1995; Rose, 1972) (figs. 1 and 3). A high degree of spatial variability of aquifer properties exists within each depositional province. Within the San Marcos Platform, the regional dense member (RDM) (fig. 3) at the base of the Person Formation of the Edwards Group is a unit between the Person Formation and the Kainer Formation (Rose, 1972) characterized by very small permeability relative to other units of the Edwards aquifer. In some areas, the RDM may separate overlying freshwater from the underlying brackish water (Groschen, 1994). The depth of the RDM was used to subdivide the single layer MODFLOW models into two model layers (Lindgren and others, 2011b). In the western part of the Maverick Basin, the middle of the low-permeability McKnight Formation (fig. 3) was determined to be a unit that is similar to the RDM within that depositional province. Stratigraphic determinations of the top altitude and thicknesses of the RDM and midpoint of the McKnight Formation were made across the freshwater extent of the Edwards aquifer to map a thin unit that is conceptually referred to as the middle part of the Edwards aquifer (fig. 3) in this report. Within the Devils River Trend, a unit similar to the middle of the McKnight Formation and the RDM does not exist; thus, the midway point of the Devils River Limestone was used as a marker for the top altitude of the middle part of the Edwards aquifer in this area. The middle part then divides the aquifer into an upper part of the Edwards aquifer and a lower part of the Edwards aquifer. The upper part is representative of the Salmon Peak Formation and upper McKnight Formation in the Maverick Basin, the top of the Devils River Limestone in the Devils River Trend, and the Georgetown and Person Formations in the San Marcos Platform. The lower part of the Edwards aquifer is representative of the bottom of the McKnight Formation and the West Nueces Formation in the Maverick Basin, the bottom of the Devils River Limestone in the Devils River Trend, and the Kainer Formation in the San Marcos Platform (fig. 3). The Edwards aquifer was informally divided and named into three parts to aid in model conceptualization, implementation, parameterization, and discussion, and is not intended for use as naming conventions for any other purposes outside of this report.

Previously published information on top and bottom altitudes of the Edwards aquifer freshwater extent, as well as the extensive faults, is summarized by Lindgren and others (2004). The top and bottom altitudes of the Edwards aquifer model (Lindgren and others, 2004) were also used in the diffuse-flow model of Lindgren (2006), the specific model updated for this report. In addition to the top and bottom altitudes of the model extent of Lindgren and others (2004) for the model described in this report, interpretations of the tops and bases of hydrostratigraphic units were made based on cross-sectional information presented in Rose (1972), which was supplemented by data from geophysical logs (Railroad
Commission of Texas, 2012). Interpretations of the top and base of the middle part of the Edwards aquifer were also made from the same downdip cross-sections and geophysical logs to extend this vertical aquifer subdivision (fig. 3) downdip as well. Geographic information system (GIS)-generated raster grids of top and bottom altitude information were interpolated for the revised downdip area using a natural neighbor interpolation method in ArcMap (Esri, 2015b). Updip of the 10,000$\mathrm{mg} / \mathrm{L}$ dissolved-solids contour (A.L. Schultz, private consultant, written commun., 2000), the top and bottom altitudes and faults are the same as those of Lindgren and others (2004) and Lindgren (2006). Downdip of the 10,000-mg/L dissolved-solids contour, the raster grids were used to populate the updated extent of the model grid.

\section{Review of Groundwater-Flow System}

Groundwater recharge to the Edwards aquifer is from rainfall infiltration and stream losses within the recharge zone of the aquifer (which is the primary source of recharge), and to a lesser extent, groundwater flow (flux) from the underlying Trinity aquifer (figs. 2-3) (Lindgren and others, 2004). From the recharge zone, groundwater moves in directions controlled mainly by regional and local faulting (Maclay and Land, 1988), but the general trend is for the water to move downdip into the confined part of the aquifer (fig. 2). In general, groundwater moves through fractured, highly transmissive rocks and is deflected by faults towards the east and northeast to discharge at many springs (fig. 1), of which Comal Springs and San Marcos Springs are the largest (Lindgren and others, 2004). Groundwater recharge from the Trinity aquifer is derived from the underlying Glen Rose Limestone (figs. 2-3), which is the uppermost unit of the Trinity aquifer (Lindgren and others, 2004). Historically, naturally occurring springs throughout the region were the primary locations of groundwater discharge. As groundwater withdrawals by wells increased throughout the freshwater extent of the aquifer to meet the needs of a growing population, industry, and agriculture (Lindgren and others, 2004), groundwater began discharging at both springs and wells.

\section{Water-Quality Zones}

The freshwater zone of the Edwards aquifer is delineated to the south by a zone of brackish water (transition zone) where the aquifer transitions from fresh to saline water (fig. 4). The saline zone is located downdip of the transition zone. The transition zone minimizes the downdip flow of freshwater from the Edwards aquifer. Typically it has been defined on maps as the zone exceeding the 1,000-mg/L contour of equal dissolved-solids concentration (hereinafter referred to as the "1,000-mg/L dissolved-solids contour"). The 1,000-mg/L dissolved-solids contour is commonly referred to as the "bad-water line," which coincides with the updip boundary of the transition zone (Schultz, 1993, 1994). 


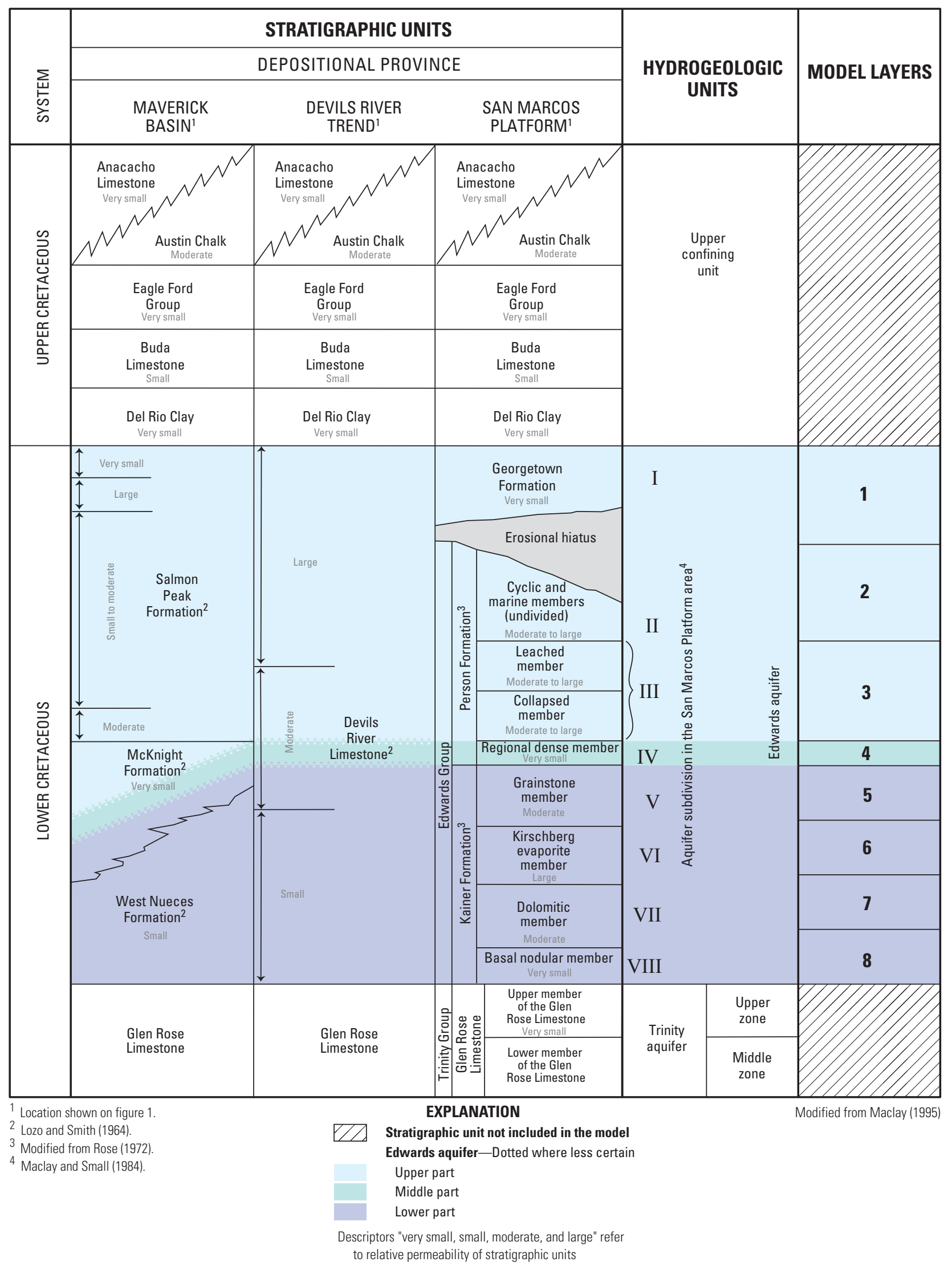

Figure 3. Correlation of Cretaceous stratigraphic units and hydrogeologic units, relative permeability and model layers in the Edwards aquifer model area, San Antonio region, Texas (modified from Maclay, 1995, fig. 11). 
Previous models of the Edwards aquifer in the San Antonio region (Klemt and others, 1979; Maclay and Land, 1988; Thorkildsen and McElhaney, 1992) have used the 1,000-mg/L dissolved-solids contour as the southern boundary of the groundwater-flow model area. Other models have used the more conservative $10,000-\mathrm{mg} / \mathrm{L}$ dissolved-solids contour as an estimate of the southern boundary of the groundwater-flow model area (Lindgren and others, 2004; Lindgren, 2006, Lindgren and others, 2011b). The simulation for this study focused on the transition zone. Relocation of the southern boundary to minimize boundary effects on model results is described in the "Hydrologic Boundary Conditions" section of this report.

The thickness of the transition zone is highly variable. The contours of dissolved-solids concentrations (Schultz, 1992, 1993, and 1994) are two-dimensional plan view contours, whereas the actual dissolved-solids concentration distribution is complex and three-dimensional (Lambert and others, 2010; Schultz, 1992, 1993, and 1994; Thomas and others, 2012). Furthermore, the water-quality data and geophysical log estimates of Schultz (1992, 1993, and 1994) were based on spatial information recorded during several decades. Therefore, considerable uncertainty exists as to the spatial and temporal distribution of dissolved-solids throughout the aquifer. Additionally, a disparity exists between the amount of data available for characterizing the freshwater, transition, and saline zones - a large amount of data is available for characterizing the freshwater zone, whereas few data are available for characterizing the transition and saline zones. Farther downdip from the "bad-water line," data on heads, concentrations, and aquifer properties becomes increasingly scarce. This data deficit requires assumptions to be made based on expert knowledge of the system and its properties.

Dolomite dissolution within the karstic Edwards aquifer has created higher-permeability and higher-porosity preferential flow areas on the freshwater side of the "bad-water line" (Deike, 1990; Groschen, 1994; Hovorka and others, 1996; Hovorka and others, 1998). Just south of the "bad-water line," porosity enhancement through dolomite dissolution may result from close proximity to the fresh-water part of the aquifer (Hovorka and others, 1998). As stated in Hovorka and others (1998), "enhancement of matrix permeability is seen regionally near the fresh-saline interface." From Maclay and Small (1984, page 48), “a highly permeable belt of rocks exists along segments of the 'bad-water' line in areas where mixing of ground water of two different chemical types may increase the solution capacity of the water." Dolomite dissolution may be enhanced where groundwater flow rates are faster; thus, wellconnected pores may have been further enlarged (Hovorka and others, 1998). Permeability within the saline zone is strongly related to porosity, and porosity estimates from the saline zone yield a lower average porosity than the freshwater zone (Hovorka and others, 1998). The updip edge of the transition zone has the highest estimates of matrix porosity and permeability. Structural controls, such as faults, play a major role in karst development because faults can focus dissolution and thereby contribute to solution enlargement in these locations (Hovorka and others, 1998). Some groundwater may potentially flow vertically (fig. 2) along faults (Groschen, 1994), but primarily faults control the horizontal direction of groundwater flow. Groundwater flow within the freshwater and transition zones is parallel to faults (Groschen, 1994; Lambert and others, 2010).

\section{Aquifer Hydraulic and Transport Properties}

Groundwater heads and flow are controlled by hydraulic conductivity (or the analogous transmissivity) and storativity in the aquifer, whereas effective porosity is the primary control on dissolved-solids transport. Hydraulic conductivity is known to span eight orders of magnitude in the Edwards aquifer (Hovorka and others, 1998). Calibrated hydraulic conductivity values for the diffuse-flow model ranged from 3 to 50,000 feet per day (ft/day) with an average of approximately $1,500 \mathrm{ft} /$ day (Lindgren, 2006). Vertical variations of permeability exist in the Edwards aquifer (fig. 3) and, therefore, hydraulic conductivity exhibits vertical variability as well because it is related to permeability. Permeability of the saline zone is smaller than permeability in the freshwater zone; therefore, movement in the saline zone is thought to be less than in the freshwater zone (Groschen, 1994; Lambert and others, 2010).

Storage within the Edwards aquifer is defined by specific yield in the unconfined part of the aquifer (outcrop) and specific storage in the confined part of the aquifer (subcrop where heads are above the top of the aquifer). For this assessment, the aquifer was conceptualized as confined and, therefore, specific storage - the volume of water that a unit volume of aquifer releases from storage under a unit decline in hydraulic head (Freeze and Cherry, 1979)—was used for the outcrop as well as the subcrop. This modeling assumption was made because the outcrop was not the focus area of the model. Specific storage values for the calibrated, confined part of the previous models (Lindgren and others, 2004; Lindgren, 2006) were on the order of $10^{-7}$ to $10^{-6} 1 / \mathrm{ft}$ (per foot). Specific-storage parameters in the recharge zone were expected to be higher to account for specific yield, which typically is much larger than specific storage but was not simulated. Storage estimates are not well known in the transition and saline zones, but values used to calibrate the model were on the lower end of the range (Lindgren and others, 2004).

Effective porosity is a key property controlling transport of dissolved solids. Effective porosity is less than bulk porosity as it is a measure of the interconnectedness of the void space (Fetter, 1999). Effective porosity is not known on a regional scale and the spatial variability of effective porosity is not well understood. In a modeling context for contaminant transport problems, effective porosity serves as a final "tuning" parameter for matching concentration data (Zheng and Bennett, 2002), whereas hydraulic conductivity and storativity control groundwater heads and flows. Contaminant velocity is inversely proportional to effective porosity, which means velocities increase as effective porosity decreases. Effective porosity estimates are not available regionally for the Edwards aquifer because the aquifer is a complex karst system 
Contributing area

(1) Nueces-West Nueces River Basin

(2) Frio-Dry Frio River Basin

(3) Sabinal River Basin

(4) Area between Sabinal and Medina River Basins (includes Hondo and Seco Creeks)

(5) Medina River Basin

(6) Area between Medina River Basin and Cibolo-Dry Comal Creek Basins

(7) Cibolo and Dry Comal Creek Basins

8 Guadalupe River Basin

(9) Blanco River Basin

(10) Barton Springs segment contributing area (includes Barton, Williamson, Slaughter, Bear, and Onion Creeks)

\author{
Comal Creek Basins
}

$31^{\circ}$ \& BURNET/
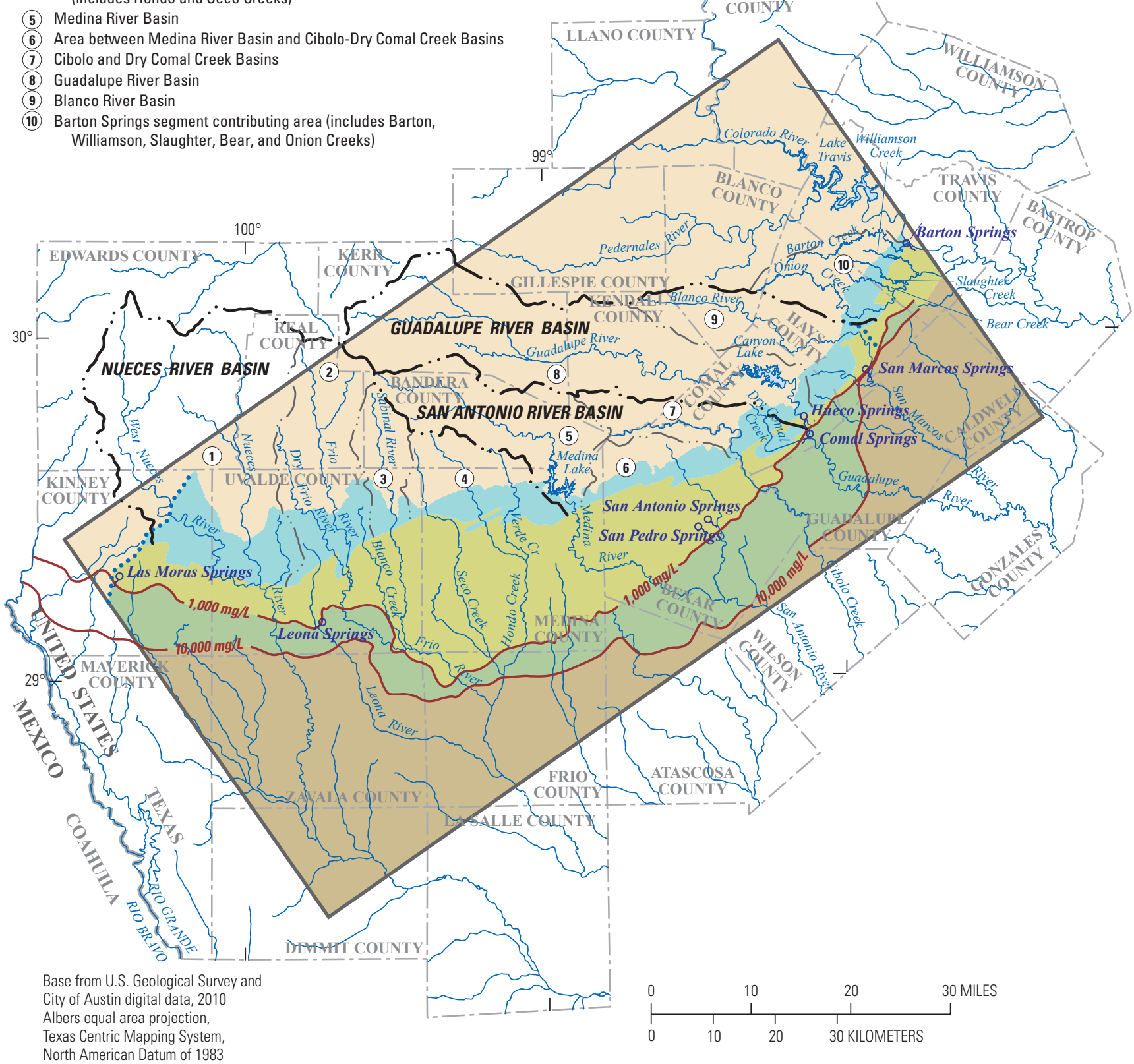

EXPLANATION
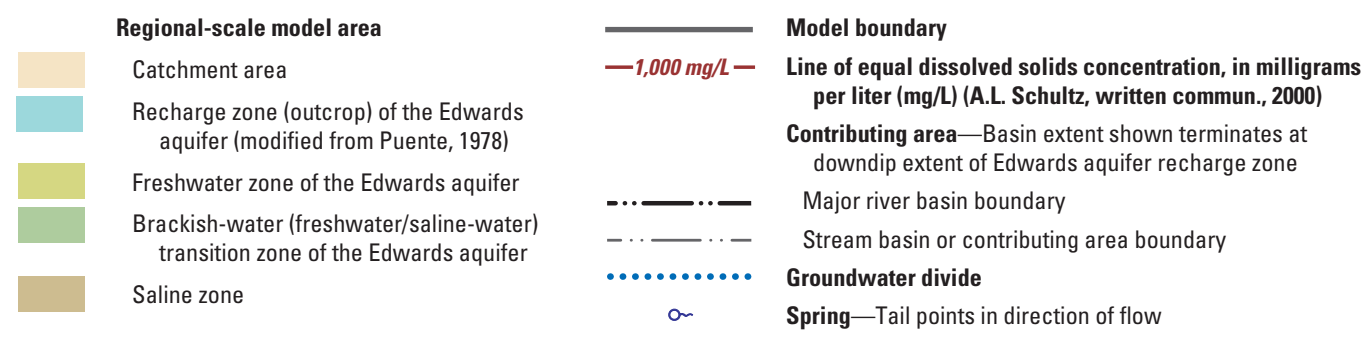

Figure 4. Recharge, freshwater, brackish-water transition, and saline zones of the Edwards aquifer, San Antonio region, Texas (modified from Lindgren and others (2011a, fig. 2). 
characterized by smaller matrix porosity as well as larger secondary porosity. Effective porosity is generally estimated on local scales from tracer tests, which may not be applicable on a regional scale. Bulk porosity estimates have been reported but how well these estimates reflect the interconnectedness of effective porosity is not well understood. An average of 0.18 was given for porosity by Hovorka and others (1996), based on plug porosity data and geophysical logs, with estimates ranging from low values of 0.04 to 0.12 to high values of 0.20 to 0.42 (Hovorka and others, 1996; Hovorka and others, 1993) with estimates up to 0.50 from cores (Hovorka and others, 1996). The matrix of the saline zone has pores that are less connected than those in the freshwater zone (Maclay and Small, 1984). Effective porosity estimates from previous modeling efforts range on the low end of reported values. Kuniansky and others (2001) used 0.015 to 0.035 for effective porosity to match estimated travel times derived from geochemical mixing models; the largest value for effective porosity used by Lindgren and others (2011a) for particle-tracking analyses was 0.01255 . A uniform average effective porosity of 0.18 was used in both the conduit-flow model (Lindgren and others, 2004) and diffuse-flow model (Lindgren, 2006) to determine backward-tracked particle travel times for comparison to geochemical age-tracer results (Musgrove and others, 2010). Results from the models indicated older groundwater ages than the geochemical results. For this assessment, a range of 0.025 to 0.50 ( 2.5 percent to 50 percent $)$ was set to allow maximum flexibility in the history-matching effort.

\section{Model Development}

The diffuse-flow model (Lindgren, 2006) included the San Antonio and Barton Springs segments of the Edwards aquifer (fig. 1). The San Antonio segment of the model was the focus area for history matching because this was the area of interest for this assessment. The San Antonio segment extends from near Brackettville, Tex. in Kinney County to the groundwater divide near Kyle, Tex. in Hays County, where the Barton Springs segment begins and extends to the Colorado River in Travis County. Both segments were simulated in the model because the groundwater divide near Kyle (fig. 1) is poorly defined and varies temporally (LBG-Guyton Associates, 1995) and, therefore, cannot be statically defined.

The modeling was completed in two distinct phases: (1) the history-matching phase and (2) the predictive phase. Development of the history-matched model, within the history-matching phase, included construction of the model grid (both horizontal discretization and vertical layering), implementation of model boundary conditions and stresses, development of initial conditions, and calibration through history matching. History matching involves adjusting model input parameters to acquire a sufficient fit of the modelsimulated equivalents to the historical real-world observation dataset. The observation dataset consists of raw and processed data collected during a distinct time that the model will be adjusted to "match." Another expectation of history matching, secondary to ensuring the model can reproduce groundwater responses within some time period, is improving the reliability of model predictions. History matching is intricately linked with conceptualization and with the prediction of interest in two ways: (1) the parameter estimation process within the history-matching exercise may yield results that indicate changes needed for the model, such as input parameters, boundary conditions, and initial conditions; and (2) the prediction of interest guides the history-matching effort as the model and observation dataset need to be in agreement with and supportive of the prediction.

\section{History-Matching Phase}

For the history-matching phase, the major changes from the diffuse-flow model (Lindgren, 2006) that were incorporated into the history-matched model (1999-2009), are summarized:

1. More active model cells (fig. 5) were used to simulate the transition zone and saline zone downdip of the freshwater extent (fig. 4).

2. The one-layer model was converted to an 8-layer model (fig. 3) to better represent vertical aquifer heterogeneity and anisotropy as well as simulate variable-density flow and transport. Discussion of the model is in terms of the "upper" (layers 1-3), "middle" (layer 4), and "lower" (layers 5-8) parts of the Edwards aquifer based on the hydrostratigraphy.

3. SEAWAT version 4 was used to explicitly simulate variable-density flow and transport.

4. The history-matching period was updated to 1999-2009.

5. Parameter estimation, through history matching, was executed using highly parameterized inversion with PEST to calibrate to heads, discharges at major springs, and dissolved-solids concentrations at wells.

Next, the predictive phase needs to be planned early during the history-matching phase because the model design and parameterization for the history matching need to meet the intended use of the model, that is, the predictions of interest. For example, if the prediction of interest is to estimate drawdown around a well field under hydrologically wet conditions, the history-matching must contain wet conditions in the period of record and the well-field must be appropriately simulated in the model. The predictions of interest in this assessment are (1) changes in dissolved-solids concentration at production wells near the transition-zone interface, (2) total spring discharge at Comal and San Macros Springs, and (3) head at well J-17 during drought conditions of 1950-56. The predictions are mentioned here for readers to bear in mind the intended use of the model during the discussion of the model development and history-matching effort. 


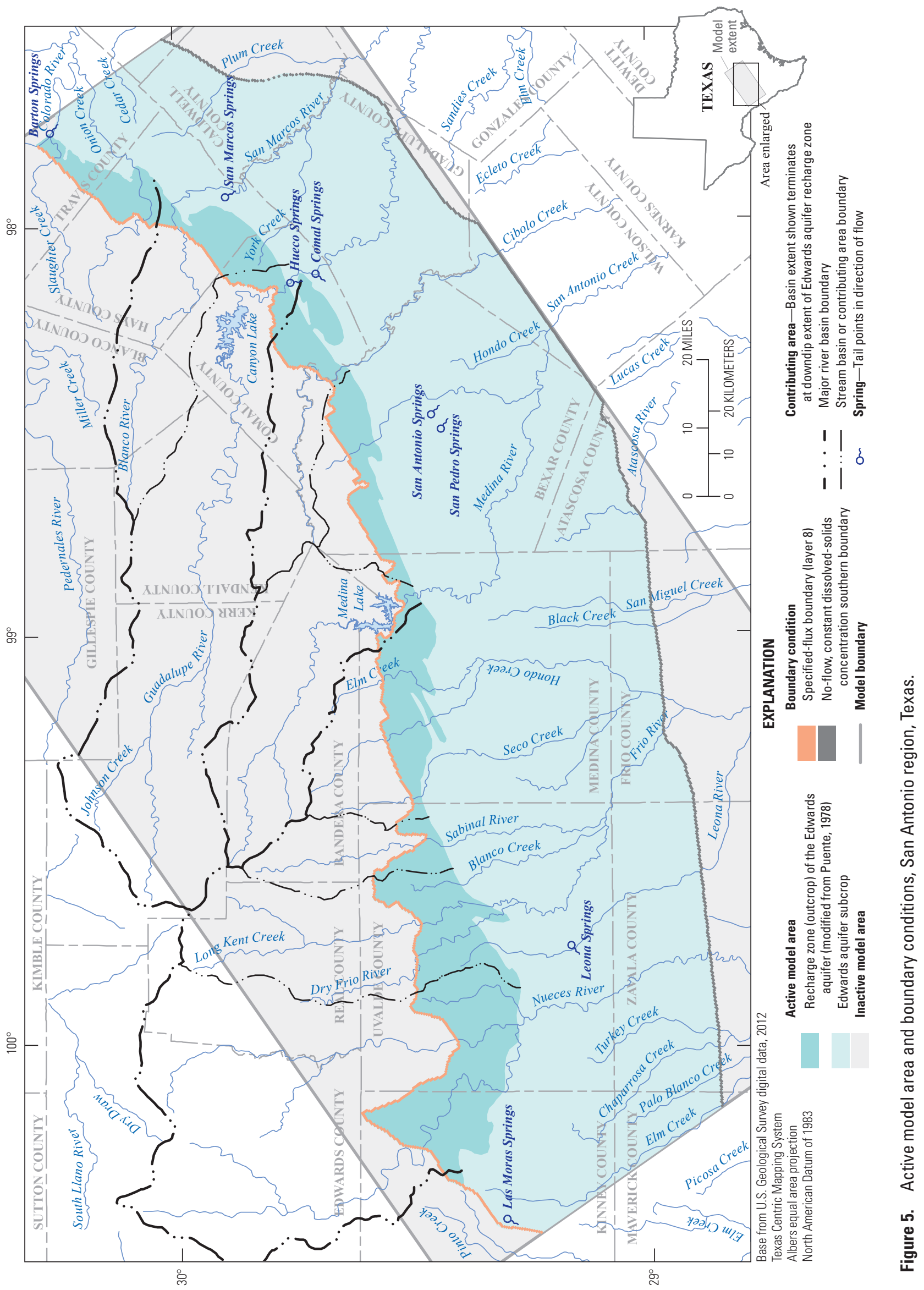




\section{Discretization}

The horizontal grid discretization from the diffuse-flow model (Lindgren, 2006) was retained in the SEAWAT model. The uniformly spaced finite-difference grid has 370 rows and 700 columns. The dimensions of the grid cells are uniformly 0.25 mile (1,320 feet) along rows and columns. The grid was oriented to align with the regional direction of groundwater flow (Lindgren and others, 2004) and the major faults (fig. 6) in the Balcones fault zone, with preference given to the direction of groundwater flow and orientation of major faults near Comal and San Marcos Springs. Accordingly, the grid was rotated 35 degrees counterclockwise from horizontal.

The grid was refined to include eight model layers to better represent vertical heterogeneity and groundwater flow and because SEAWAT requires a greater level of vertical discretization than MODFLOW. Also, the aquifer was divided based on the hydrostratigraphic units defined for the Edwards aquifer (fig. 3) into the upper (layers 1-3), middle (layer 4), and lower (layers 5-8) parts of the Edwards aquifer as discussed in "Updated Conceptualization of Hydrogeology for Numerical Model" section. Subdividing the Edwards aquifer into upper, middle, and lower aquifer parts allows for better representation of vertical groundwater flow, which is controlled by the vertical hydraulic conductivity of the middle part of the Edwards aquifer. Conceptually, the middle part of the Edwards aquifer might impede, or allow, vertical flow between the upper and lower parts of the Edwards aquifer, but this vertical flow is dependent on any information in the observation dataset regarding vertical head differences. Because conceptualization of the middle part of the Edwards aquifer was designed to control vertical flows between the subdivisions, it was assumed that horizontal variations in specific storage and effective porosity could be ignored and represented with uniform aquifer properties. Following the approach of Lindgren and others (2011b), isotropic conditions were assumed (vertical hydraulic conductivity of each model cell was equal to the horizontal hydraulic conductivity). Multiple layers were used for the upper and lower parts of the Edwards aquifer (three layers and four layers, respectively [fig. 3]) to allow for better simulation of variable-density flow and transport (that is, discretize the transition zone). However, layers within each aquifer subdivision contained the same property values.

The top (top of layer 1) and bottom (bottom of layer 8) of the model are consistent with previous models of the Edwards aquifer (Lindgren and others, 2004; Lindgren, 2006; Lindgren and others, 2011b) for the active model area inherited (obtained from) from these models. The bottom of the model was calculated by subtracting the thickness of the Edwards aquifer (fig. 6b) from the top of the aquifer (fig. 6a). The model in this assessment simulates a larger downdip extent of the aquifer than previous models; therefore, the top and bottom of the new active extent of the model is based on the interpolated top and bottom of the Edwards aquifer as discussed in the "Updated Conceptualization of Hydrogeology for Numerical Model" section. Stratigraphic determinations of the top of layer 4 were made and interpolated (fig. 7a). The thickness of the upper part of the Edwards aquifer was calculated by subtracting the top of layer 4 from the top of layer 1 (fig. 6a). The upper part of the Edwards aquifer was then subdivided into three layers of equal thickness. The thickness of layer 4 (fig. 7b), as based on stratigraphic determinations, was subtracted from the top of layer 4 to determine the top of layer 5. The resulting lower part of the Edwards aquifer (top of layer 5 to the bottom of layer 8) was subdivided into 4 equal parts to form layers 5 through 8 .

As the Edwards aquifer is a sloping aquifer with an outcrop recharge zone at the surface corresponding to layers 5 through 8 which lie underneath a confined subcrop part of the aquifer farther downdip (layers 1 through 4), the active extents of each layer are different depending upon the water saturation of each cell and if the cell lies within the subcrop or outcrop. Model layer 8 has the largest number of active cells, as this layer includes the bottom of the Edwards aquifer. Shallower depths in the aquifer have smaller number of active cells for each layer. Model layer 1 has the least number of active model cells. The number of active layers for each row and column in the model (fig. 8) was determined based on the active cells in the diffuse-flow model (Lindgren and others, 2004) and layer bottoms and was modified where needed to aid model convergence. A cell was made inactive if the head fell below the bottom of the cell. Other inactive areas of the model grid are inactive because the Edwards aquifer does not exist at that location (north of the recharge zone) or it is not within the area of interest (deep in saline zone) (figs. 4 and 8).

The model was temporally discretized to have monthly stress periods from January 1999 through December 2009, for a total of 132 stress periods. Therefore, the model simulates monthly changes in recharge, Trinity aquifer flux, groundwater withdrawals, and spring discharges.

\section{Hydrologic Boundary Conditions}

Boundary conditions for the model are set along the lateral model boundaries of the active model area (fig. 5) and are specified where water is entering or leaving the aquifer. Boundary conditions include recharge from precipitation in the recharge zone by the Recharge Package (RCH), flux from the underlying Trinity aquifer by the Well Package (WEL), discharge from groundwater withdrawals by the WEL and discharge to springs by the Drain Package (DRN) (Harbaugh, 2005). For SEAWAT, dissolved-solids concentrations for water are required to be specified for cells in which water is entering the aquifer (RCH or WEL) and are assumed to be equal to the concentration in the cell for those cells where groundwater leaves the aquifer.

\section{Lateral Model Boundaries}

The western, northern, and eastern lateral extents of the active part of the model are the same as for the diffuse-flow model (Lindgren, 2006), whereas the southern extent has been 


\section{A. Faults and altitude of top of Edwards aquifer active model area}

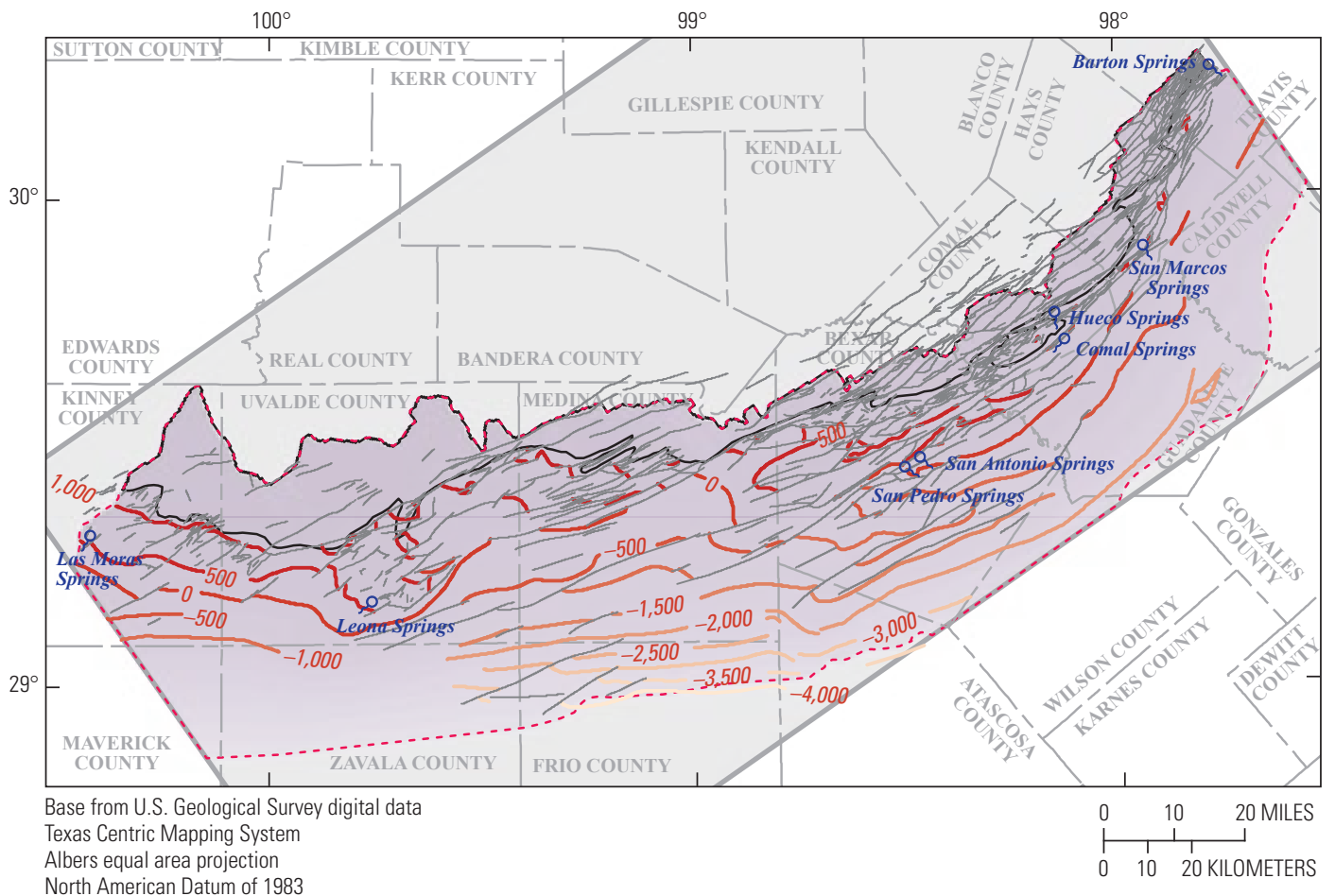

\section{B. Thickness of Edwards aquifer active model area}

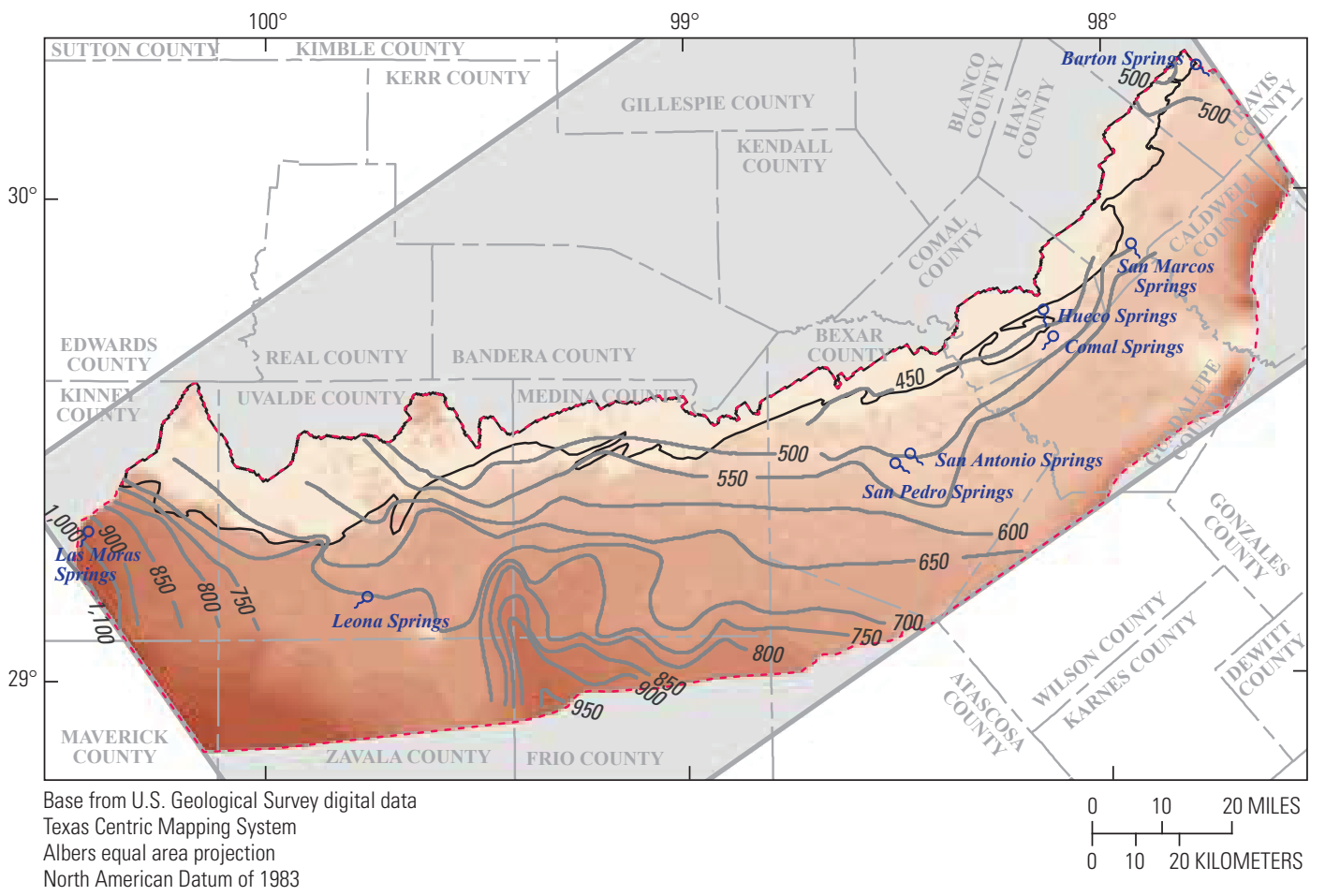

EXPLANATION

Altitude of top of Edwards aquifer active model area, in feet-Datum is National Geodetic Vertical Datum of 1929

1,408

$-2,000$

$-5,507$

Model extent

Recharge zone boundary (modified from Puente, 1978)

Fault (Lindgren and others, 2004)

Structure contour-Shows altitude of top of Edwards aquifer. Interval 500 feet. Datum is National Geodetic Vertical Datum of 1929. Modified from Collins and Hovorka, 1997

1,000

500

0

$-500$

$-1,000$

$-1,500$

$-2,000$

$-2,500$

$-3,000$

$-3,500$

$-4,000$

- - - - Active model-area boundary

on Spring-Tail points in direction of flow

\section{EXPLANATION}

Thickness of Edwards aquifer active model area, in feet 24

700

1,228

Model extent

Recharge zone boundary (modified from Puente, 1978)

Line of equal thicknessIntervals 50 and 100 feet. Modified from Hovorka and others, 1996

- - - - Active model-area boundary

on Spring-Tail points in direction of flow

Figure 6. $A$, Faults and altitude of top of Edwards aquifer active model area, and $B$, thickness of Edwards aquifer active model area, San Antonio region, Texas. 


\section{A. Altitude of top of middle part of Edwards aquifer}

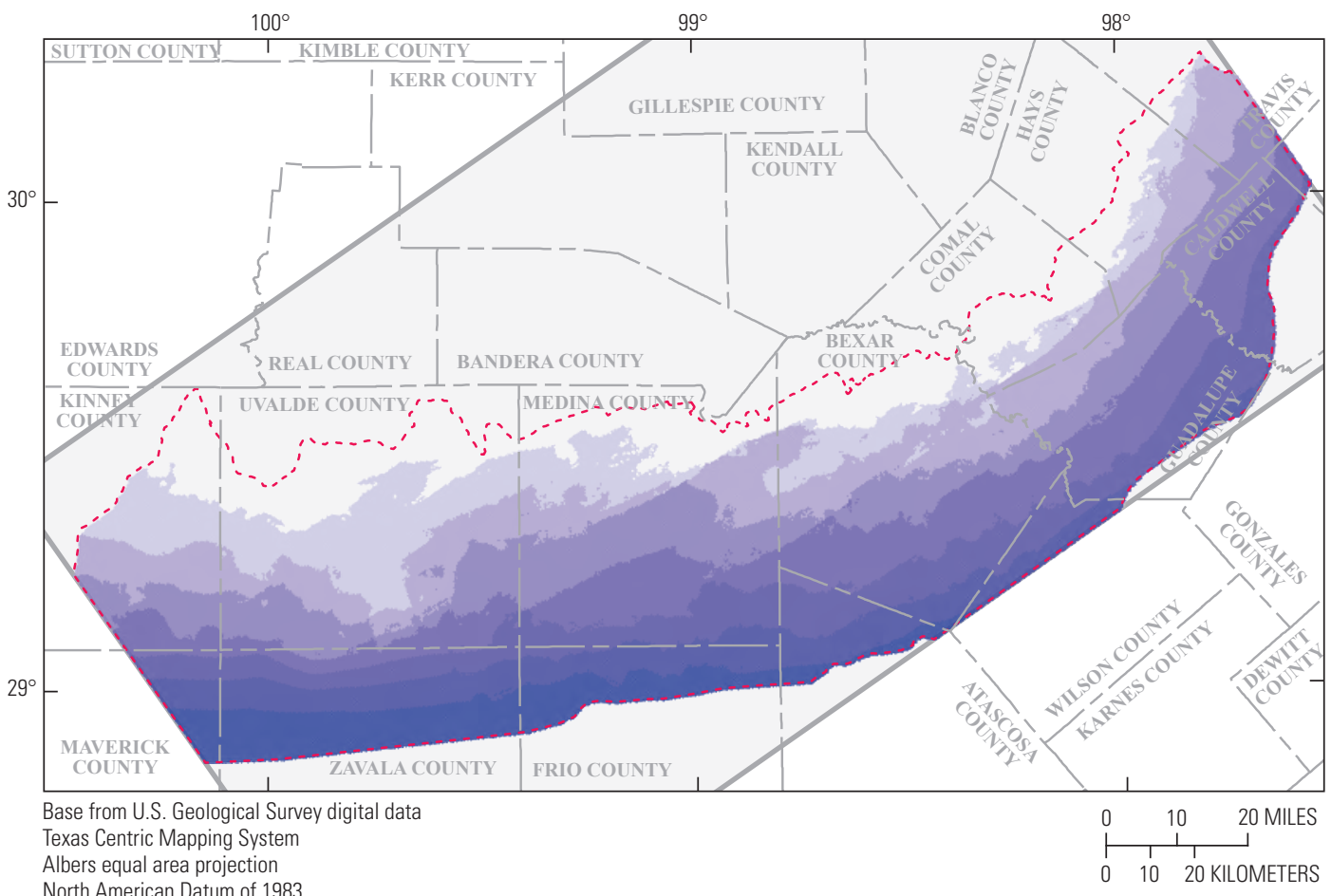

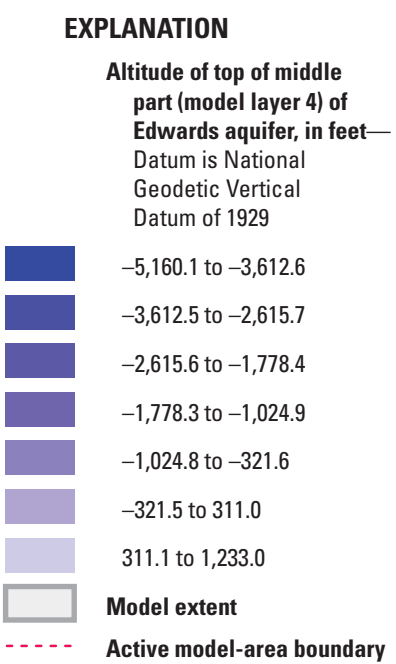

\section{B. Thickness of middle part of Edwards aquifer}

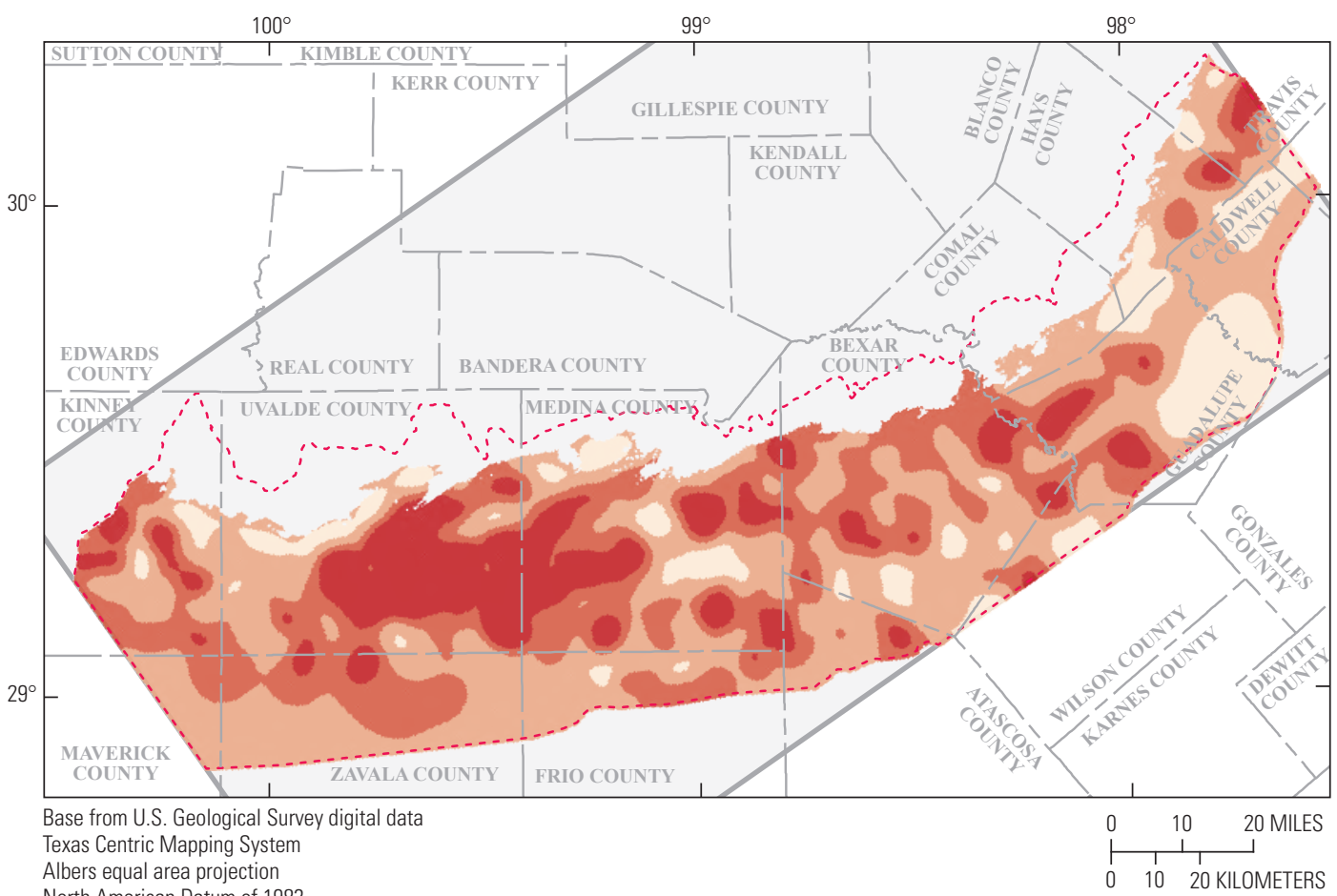

\section{EXPLANATION}

Thickness of middle part (model layer 4) of Edwards aquifer, in feet

12.9 to 21.0

21.1 to 26.0

26.1 to 31.0

31.1 to 44.6

\section{Model extent}

Active model-area boundary

Figure 7. A, Altitude of top, and $B$, thickness of the middle part of the Edwards aquifer (model layer 4), San Antonio region, Texas. 


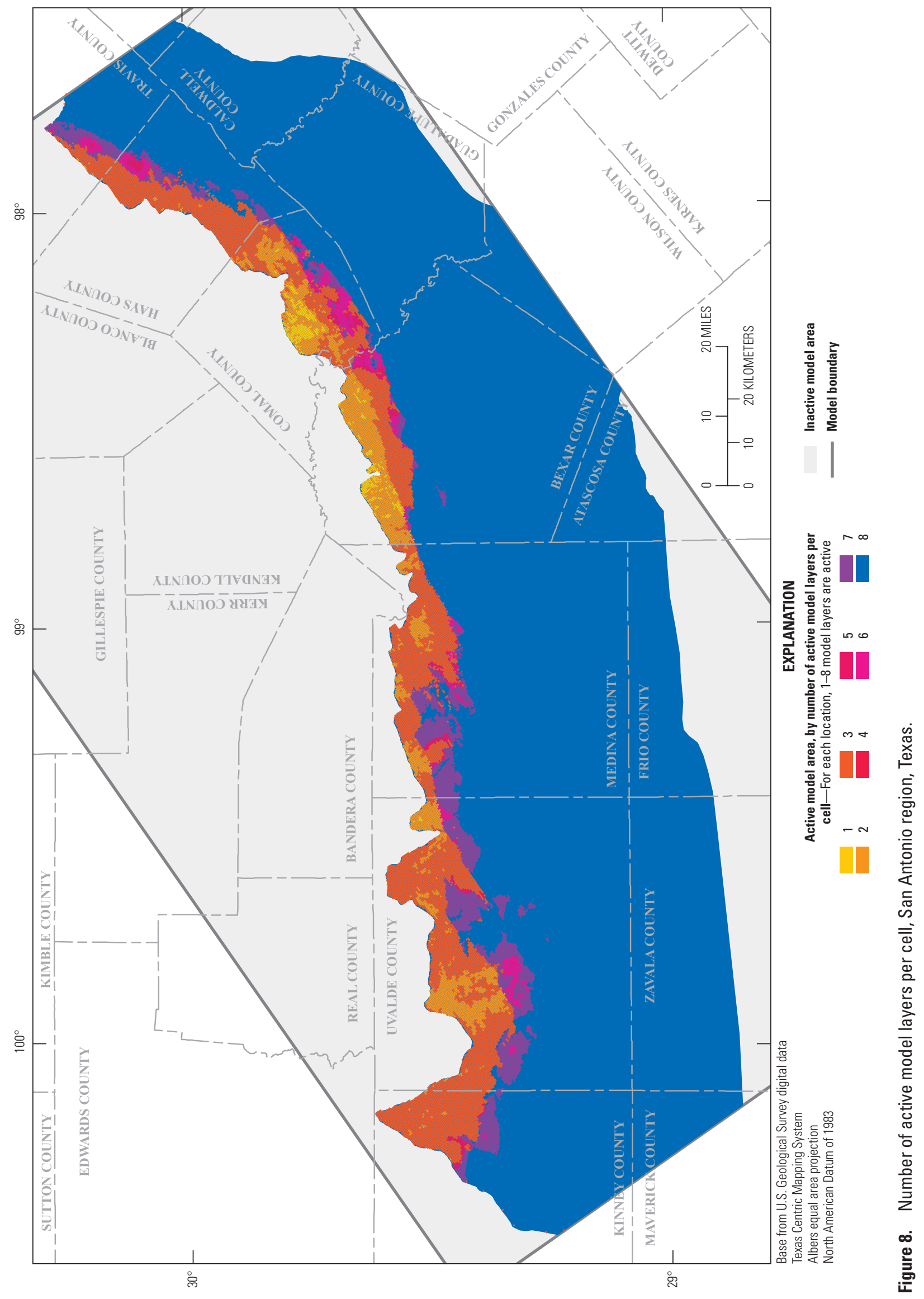


extended downdip. The northern extent of the model corresponds to the northern extent of the recharge zone (fig. 5). The northern part of the eastern extent of the active part of the model corresponds with the Colorado River (fig. 5). The western and southern extents of the active part of the model are less well-defined hydrogeologic boundaries. The western extent of the active part of the model coincides with a poorly defined groundwater divide (fig. 1) near Brackettville in Kinney County (Garza, 1966; LBG-Guyton Associates, 1995)minimal flow across this boundary is generally assumed. Thus, the southern part of the western model boundary was simulated as a no-flow boundary similar to the diffuse-flow model (Lindgren, 2006). Last, the northern part of the western extent of the active part of the model was simulated as a specifiedflux boundary using WEL which better simulates heads near the western boundary. This boundary condition was also similar to the boundary condition for the diffuse-flow model (Lindgren, 2006).

The 10,000-mg/L dissolved solids concentration contour (A.L. Schultz, private consultant, written commun., 2000) has been used several times in previous MODFLOW models as a no-flow boundary (Lindgren and others, 2004; Lindgren, 2006; Lindgren and others, 2011b). Because the objective of this modeling effort was to simulate the transition zone, the southern boundary (no-flow, constant dissolved-solids concentration) needed to be moved to minimize boundary effects. The initial goal was to set the southern boundary at the estimated 35,000-mg/L dissolved-solids concentration contour, but insufficient data prevented a full characterization of this concentration contour on a regional scale. Therefore, the boundary was based on an approximate location of the 35,000-mg/L contour (fig. 9) where data were available (described in the "Initial Dissolved-Solids Concentrations" section of the "History-Matching Phase" section), and in areas where data were scarce, the boundary was set sufficiently far downdip from the 10,000-mg/L contour. This boundary was based on the assumption that any groundwater flow moves parallel to this boundary, and flow across this boundary is assumed to be minimal.

The eastern extent of the active part of the model is consistent with the extent of Lindgren (2006). However, the northern part of the eastern boundary located at the Colorado River is simulated as a no-flow boundary condition in this assessment (fig. 5). The Colorado River serves as a regional sink (groundwater discharge), but is a small component of the groundwater budget far away from the predictive area of interest. Therefore, any effects of this boundary on results in the predictive area of interest should be minimal. Spring discharge is simulated within the model at Barton Springs near the eastern boundary; Barton Spring discharges to the Colorado River (fig. 5).

\section{Groundwater Recharge}

Groundwater recharge is specified where water enters the Edwards aquifer. The two sources of recharge to the Edwards aquifer are stream losses and rainfall infiltration in the recharge zone and, to a lesser extent, flux from the underlying Trinity aquifer. Concentrations of dissolved solids for flux from the $\mathrm{RCH}$ and for the underlying Trinity aquifer were set to $325 \mathrm{mg} / \mathrm{L}$, which is assumed to be background dissolvedsolids concentration for this assessment and is near the median of $313 \mathrm{mg} / \mathrm{L}$ dissolved-solids concentration determined by Musgrove and others (2010) from groundwater sampled in the San Antonio segment of the Edwards aquifer.

Recharge to the Edwards aquifer occurs primarily by seepage from streams to the aquifer as these streams cross the recharge zone (fig. 5) (Lindgren and others, 2004; Maclay, 1995). Additional recharge is from rainfall infiltration in the interstream areas of the recharge zone. A Neumann boundary condition (Franke and others, 1987), which is also referred to as a specified-flow (Anderson and Woessner, 1992) or specified-flux (Winston, 2015) boundary condition, was implemented using the RCH (Harbaugh, 2005) to simulate groundwater recharge. Recharge was assigned in the same manner as was done in Lindgren and others (2004). Monthly recharge rates were applied for the transient simulation period (1999-2009). The recharge zone corresponds to cells in model layers 5 through 8 in the outcrop area (figs. 3 and 5), and, therefore, recharge was applied into the topmost active model layer for each cell in the $\mathrm{RCH}$.

A Neumann boundary condition was implemented for the northern model boundary to account for inflow from the underlying Trinity aquifer (figs. 2 and 5). The boundary condition was implemented using the WEL (Harbaugh, 2005) similar to what was used in previous models (Lindgren and others, 2004; Lindgren, 2006; Lindgren and others, 2011b). The assumption was made that water-level fluctuations in the Trinity aquifer near the northern boundary are similar to water-level fluctuations in the Edwards aquifer, resulting in a constant hydraulic gradient and rate of flow across the boundary, which is consistent with assumptions in previous models (Lindgren and others, 2004; Lindgren, 2006, Lindgren and others, 2011b). For this report, the constant fluxes at this boundary from the one-layer diffuse-flow model (Lindgren, 2006) were applied to the corresponding model cell locations (row, column) for model layer 8 (bottom model layer) for all stress periods.

\section{Groundwater Discharge}

Groundwater discharge is specified for the model or calculated by the model where water leaves the Edwards aquifer. Groundwater primarily discharges from the Edwards aquifer through withdrawals at wells and as discharge at springs. A small amount of groundwater also discharges to the Colorado River. In SEAWAT, dissolved-solids concentrations at groundwater-discharge locations are equal to the dissolved-solids concentration of the cell in which each particular boundary condition lies. Therefore, if the dissolved-solids concentration at a given cell is $325 \mathrm{mg} / \mathrm{L}$, water withdrawn from a well or 


\section{EXPLANATION}

Interpolated dissolved-solids concentration, in milligrams per liter (mg/L)

Less than or equal to 1,000

1,001 to 3,000

3,001 to 10,000

10,001 to 35,000

Greater than 35,000

Recharge zone boundary (modified from Puente, 1978)

Line of equal dissolved-solids concentration, in mg/L (A.L. Schultz, written commun., 2000)

\section{Model boundary}

- . - - Active model-area boundary

on Spring-Tail points in direction of flow Dissolved-solids concentration, in $\mathrm{mg} / \mathrm{L}$

- Less than or equal to 1,000

- 1,001 to 3,000

- 3,001 to 10,000

o 10,001 to 35,000

- Greater than 35,000

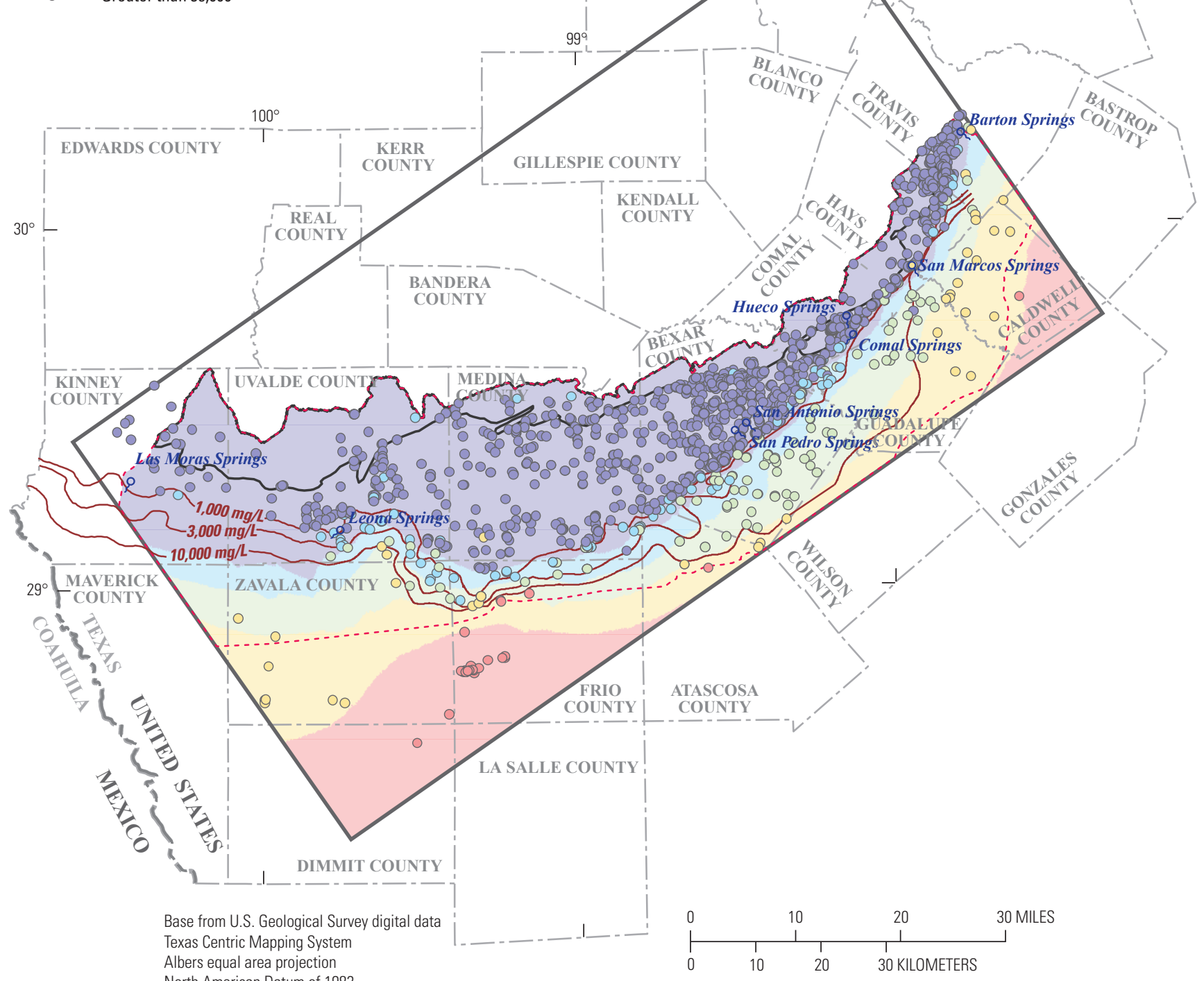

Figure 9. Lines of equal dissolved-solids concentrations (A.L. Schultz, private consultant, written commun., 2000), dissolvedsolids concentration locations of measured or estimated values based on data collected from 1930 through 2009, and distribution of interpolated dissolved-solids concentrations, San Antonio region, Texas. 
exiting the model as spring discharge in that cell is assigned a dissolved-solids concentration of $325 \mathrm{mg} / \mathrm{L}$.

\section{Well Discharge}

Groundwater withdrawals by wells were simulated as a Neumann boundary condition using the WEL (Harbaugh, 2005 ) with monthly time steps. Groundwater-withdrawal data were compiled and distributed within the model grid to simulate the period from 1999 through 2009. Withdrawal data from 2000 through 2009 were provided by water-use category by the Edwards Aquifer Authority (EAA), SAWS, Bexar Metropolitan Water System (Bexar Met), and Fort Clark Municipal Utility District (MUD). The 1999 withdrawal data were obtained from the conduit-flow MODFLOW model of the Edwards aquifer (Lindgren and others, 2004).

Site-specific withdrawals were provided by several agencies and by the water-use categories that included municipal, industrial (includes manufacturing, mining, and power generation), irrigation, and livestock (Edwards Aquifer Authority, written commun., 2004, 2012; Bexar Metropolitan Water System, written commun., 2004, 2012; Fort Clark Municipal Utility District, written commun., 2004, 2012). Site-specific withdrawal data provided as annual totals were parsed to the appropriate stress period (months) by the same methods discussed in Lindgren and others (2011b). Municipal, industrial, irrigation, and livestock withdrawals represent monthly withdrawals except for some withdrawals from EAA. Withdrawal data from SAWS were provided by well field and distributed evenly per well based on the number of active wells (San Antonio Water System, 2012). Irrigation withdrawal data were also provided by the Texas Water Development Board (TWDB) by county (Texas Water Development Board, 2004) and were spatially distributed to a site-specific location for the land-use categories of row crops, small grains, and orchards/ vineyards.

The vertical assignment of withdrawals to a model layer was done on the basis of the percentage of the well open interval in each of the model layers and the transmissivity of the model layer. If a well was open in more than 50 percent of a layer, then this layer was included for that well, except for layer $4(\mathrm{RDM})$ in which no water was withdrawn. Where well construction information was not available, the well was assumed to be open to the entire thickness of the Edwards aquifer. Well locations and average annual groundwater withdrawals during 1999-2009 are shown in figure 10, and ranged from less than 1 to more than 22,000 acre-feet per year (acre-ft/yr).

\section{Spring Discharge}

A Cauchy boundary condition (Anderson and Woessner, 1992; Franke and others, 1987), also known as a head-dependent flux boundary condition, was implemented to simulate groundwater discharge from major springs (Las Moras, Leona, San Pedro, San Antonio, Comal, San Marcos, and Barton Springs; fig. 1) using the DRN (Harbaugh, 2005). The altitude of the spring orifice and the spring conductance in the DRN control the spring discharge from the model (Harbaugh, 2005). Because Barton Springs and Las Moras Springs are near model boundaries, these springs were simulated to allow groundwater to discharge from the model, but spring discharge observation data were not used for the purpose of history matching. Data from Barton Springs were not used for history matching because the Barton Springs segment of the Edwards aquifer is not the focus of this model or previous models of the study area (Lindgren and others, 2004; Lindgren, 2006; Lindgren and others, 2011b). Data from Las Moras Springs were not used for history matching because much of its discharge might be derived from west of the western model boundary (Lindgren and others, 2004) (fig. 1). Hueco Springs (fig. 1), in Comal County north of Comal Springs, was not simulated because of the complexity of the flow relations between the Edwards and Trinity aquifers in the area of the springs and because much of the Hueco Springs discharge might be derived from the Trinity aquifer (Lindgren and others, 2004).

\section{Initial Conditions}

Transient models require initial conditions, also referred to as starting conditions, for the beginning of the model simulation. Previous MODFLOW models (Lindgren and others, 2004; Lindgren, 2006; Lindgren and others, 2011b) required initial heads, but because the history-matched model (1999-2009) documented in this report is a transient SEAWAT model, both initial heads and initial dissolved-solids concentrations at the start of 1999 are required.

\section{Initial Heads}

A constant-density version of the model was initially run under steady-state conditions by using MODFLOW-2005 (Harbaugh, 2005) to determine initial-head conditions for each of the eight layers in the model. This steady-state model was based on long-term (1978-1999) average conditions of groundwater recharge and discharge. Heads from the steadystate MODFLOW model were used as initial heads in the transient SEAWAT model. It is expected that matches to observation data during the first year of the history-matching period may be less desirable than matches to the following years as any errors in estimation of initial heads should be dampened out by the second year of the model simulation.

\section{Initial Dissolved-Solids Concentrations}

The initial dissolved-solids concentrations (fig. 9) used in the model were spatially interpolated from existing concentration (before 1999) data including water-quality samples and geophysical logs from Schultz (1992, 1993 and 1994). Because data were sparse in parts of the study area, two additional datasets were added: (1) groundwater withdrawal locations from the model (assuming a dissolved-solids background concentration of $325 \mathrm{mg} / \mathrm{L}$ ) and (2) transect well 


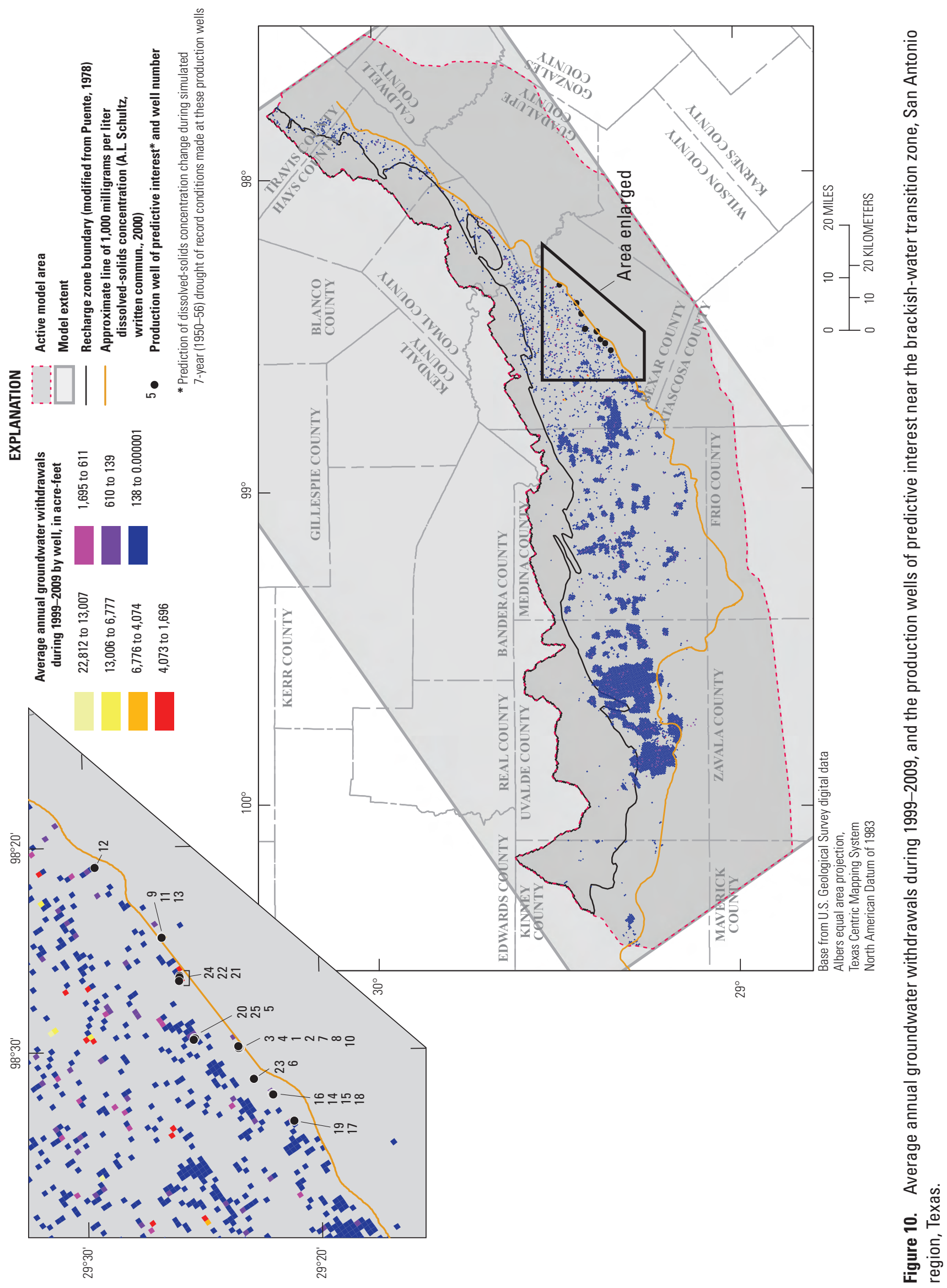


dissolved-solids concentration estimates obtained from Lambert and others (2010).

Dissolved-solids concentration data from 1930 through 2009 were obtained from the USGS National Water Information System (NWIS) (U.S. Geological Survey, 2013), the TWDB Groundwater Database (Texas Water Development Board, 2013), and the USGS National Produced Waters Geochemical Database (Blondes and others, 2013). Dissolvedsolids concentration data points for data collected from 1999 through 2009 were used for the observation dataset (discussed in detail in the "Calibration through History Matching" section). Dissolved-solids concentration data before 1999 from these databases (including the work of Schultz) were used to form the initial concentrations dataset (fig. 9). If construction information was not available for the well or a sampling depth was not given, then the dissolved-solids concentration was not used.

The work of Schultz (1992, 1993, 1994; A.L. Schultz, private consultant, written commun., 2000) to characterize dissolved-solids concentrations was used for estimating the distribution of the transition zone within the Edwards aquifer. Schultz's publications (1992, 1993, and 1994) provide maps of well locations, depths, and dissolved-solids concentrations. These data were used to create two-dimensional contours of equal dissolved-solids concentration regionally for the Edwards aquifer. The dissolved-solids data used to create the concentration contours in Schultz's publications (1992, 1993, and 1994) were georeferenced by using Esri ArcMap 10.0 (Esri, 2015a) and digitized to supplement the other dissolvedsolids data compiled.

Few data were available to characterize dissolvedsolids concentrations downdip of the historical 10,000-mg/L dissolved-solids contour by Schultz (A.L. Schultz, private consultant, written commun., 2000). Many boreholes have been drilled in south-central Texas for oilfield exploration and are present downdip of the transition zone. The Railroad Commission of Texas maintains borehole geophysical logs collected from wells that intersect the Edwards aquifer that can provide valuable information about the water quality of the aquifer. Available geophysical logs were compiled, reviewed, and assessed to determine if they penetrated the Edwards aquifer and contained pertinent information to calculate dissolved solids. Within the study area, 120 geophysical logs contain the necessary information. Data from geophysical logs obtained from the Railroad Commission of Texas Oil and Gas Well Logs database (Railroad Commission of Texas, 2012) were converted to estimates at depth of dissolved-solids concentrations.

Multiple techniques using borehole geophysical logs have been developed to calculate resistivity of the formation water $(R w)$ from saturated, clean (shale-free) water zones (Crain, 2013). One method used for this report and for previous studies of the transition zone, the Archie method, uses deep formation resistivity, porosity, and a cementation factor. Deep formation resistivity is the resistivity beyond the invaded zone, which is the volume close to the borehole wall where some or all of the moveable fluids have been displaced by mud filtrate (Schlumberger, 2015). A cementation factor $(m)$ of 2 is a common value for carbonates and has been used successfully in the transition zone (Schultz, 1992) and was used for this report. The resistivity of the formation water using this method was calculated by the following equation (Evenick, 2008):

$$
R_{w}=R_{t} \varnothing^{m}
$$

where

$R_{w} \quad$ is the resistivity of the formation water, in ohm-meters;

$R_{t} \quad$ is the deep resistivity of the formation beyond the invaded zone, in ohm-meters;

$\varnothing \quad$ is the porosity of the water saturated zone (the percent of the zone that is pores or voids), dimensionless, in decimal format; and

$m$ is the cementation factor, dimensionless (a cementation factor of 2 was used for this report).

Another method to calculate $R w$ is based on the understanding of spontaneous potential (SP) log responses. When the drilling mud is fresher than the formation fluid, the shale baseline is typically the most positive SP reading and has negative SP deflections in clean (shale-free) zones. The static selfpotential (SSP) is the magnitude of deflections (in millivolts) from the shale baseline, which is a response of the difference between drilling mud resistivity and $R w$. The SP method uses this relation to calculate $R w$. For the SP method to work, the zone assessed must be clean (shale-free) with at least some permeability, and the drilling mud and formation fluid must have different resistivities. The SSP, log header information, and formation constants are used to solve multiple equations to calculate $R w$ for a specific zone. The SP method, which uses SP log responses, borehole temperature, and mud filtrate resistivity values to calculate $R w$, is explained in Crain (2013).

Once $R w$ was determined by using the Archie or SP method, the fluid conductivity was calculated using the following equation:

$$
\mathrm{C}=10,000 / R_{w}
$$

where

$$
\begin{aligned}
& C \quad \text { is the conductivity of the formation water, in } \\
& \text { microsiemens per meter; and } \\
& R_{w} \quad \begin{array}{l}
\text { is the resistivity of the formation water, in } \\
\text { ohm-meters. }
\end{array}
\end{aligned}
$$

The fluid conductivity was then temperature corrected to estimate the specific conductance at 25 degrees Celsius. During previous studies of the transition zone in the San Antonio segment of the Edwards aquifer, observations of specific conductance and dissolved-solids concentration were related by regression analysis (appendix 2 of Thomas and others, 2012). Based on the established correlation between dissolved-solids concentration and specific conductance in the transition zone (Lambert and others, 2009), specific conductance values were 
converted to dissolved-solids concentration estimates using the following equation:

$$
E_{D S}=0.6522 S C+25.77
$$

where

$$
\begin{aligned}
& E_{D S} \quad \text { is the estimated dissolved-solids } \\
& \text { concentration, in milligrams per liter; and } \\
& S C \quad \text { is the specific conductance, in microsiemens } \\
& \text { per centimeter at } 25 \text { degrees Celsius. }
\end{aligned}
$$

Several factors can introduce errors into estimates of dissolved-solids concentrations calculated from geophysical logs and quality-control measures were used to assess possible errors. Where possible, the Archie and SP methods were used to estimate dissolved-solids concentrations, and an average of the two dissolved-solids concentrations was computed. Three-dimensional grids were created from dissolved-solids estimates and reviewed for outliers, which were removed from the dataset.

Dissolved-solids concentration data from the databases, reports (Schultz, 1992, 1993, 1994), and geophysical logs were combined into one dataset. Three-dimensional spatial interpolation was attempted to the 8-layer grid using threedimensional kriging, but lack of information on directional variograms (direction-dependent functions that quantify the spatial continuity or correlation of datasets) (Isaaks and Srivastava, 1989; Oliver and others, 2008) and data gaps made interpolation difficult and introduced many anomalies. Therefore, the dataset was interpolated in two-dimensions instead (the depth parameter was excluded) through kriging with PEST's "ppk2fac" and "fac2real" utilities (Doherty, 2011).

A near singular matrix during the interpolation process required declustering of the dataset to remove similar values near one another. The interpolated dissolved-solids concentration distribution (fig. 9) was used as the initial concentrations for all model layers.

\section{Requirements for SEAWAT}

SEAWAT version 4 is a well-known and widely tested three-dimensional variable-density groundwater-flow computer program developed by the USGS that couples the groundwater-flow code MODFLOW-2000 (Harbaugh and others, 2000) with the subsurface contaminant transport code MT3DMS (Zheng and Wang, 1999). SEAWAT version 4 can explicitly simulate variable-density and variable-viscosity effects on groundwater flow based on changes in both dissolved-solids concentration and temperature; however, variable-viscosity effects and heat transport were not considered in this assessment. The effect of changing density on groundwater flow is simulated in SEAWAT by coupling the groundwater-flow equation and the solute-transport advective-dispersive equation through a linear equation of state that relates water density in a cell to the dissolved-solids concentration of the water in that cell. Although SEAWAT was originally applied on a regional scale to simulate saltwater intrusion and submarine groundwater discharge in a coastal aquifer in Florida (Langevin, 2000), it has been tested and used in other settings from laboratory to regional scales and is applicable to noncoastal aquifer systems with areas of increased salinities, such as the Edwards aquifer. More information on SEAWAT can be found at the U.S. Geological Survey's SEAWAT Web page (U.S. Geological Survey, 2014) and in the user manuals (Guo and Langevin, 2002; Langevin and others, 2003; Langevin and others, 2008).

SEAWAT version 4 requires additional information not required by MODFLOW-2000 in order to simulate solute transport of dissolved solids and density-dependent groundwater flow: advection and dispersion information, the linear equation of state that relates water density to dissolved-solids concentration, dissolved-solids concentrations at boundary conditions, effective porosity, and initial concentrations. Advection was solved using the standard finite-difference method with upstream-weighting. Numerical dispersion occurs when using the finite-difference upstream-weighting method to solve for advection; therefore, longitudinal, and transverse dispersivity parameters, as well as molecular diffusion, were set to 0.0 . The reference freshwater density for SEAWAT version 4 was set to 62.4 pounds per cubic foot $\left(\mathrm{lbs} / \mathrm{ft}^{3}\right)$ and the slope of the linear equation of state was set to 0.714.

The Source/Sink Mixing (SSM) Package of SEAWAT version 4 contains information related to concentrations and locations of model sources and sinks (boundary conditions). At a model sink (where the water leaves a cell through a spring, simulated by using the DRN or production well, simulated by using the WEL), the dissolved-solids concentration of the sink within a cell will equal the concentration of water in the cell. At model sources (where water enters a cell through net recharge, simulated by using the $\mathrm{RCH}$ or from the underlying Trinity aquifer, simulated by using the WEL), the dissolved-solids concentration is specified in the SSM. The constant dissolved-solids concentration boundary condition for the southern model boundary is also specified in the SSM and was adjusted during history matching (discussed in the "Calibration Though History Matching" section) and the concentration of each cell was based on the history-matched initial dissolved-solids concentration at that cell. The Basic Transport Package (BTN) (Zheng and Wang, 1999) contains information about the effective porosity and initial dissolvedsolids concentration arrays in each layer of the model. These arrays were created as external arrays in SEAWAT so that parameter changes could be made to individual arrays during history matching.

\section{Calibration through History Matching}

Models are calibrated through the process of history matching. History matching involves adjusting model input parameters to improve the agreement between historical observations (heads, spring discharges, and dissolved-solids concentrations representative of a defined time) and modelsimulated equivalents with the presumption that a model 
that can reproduce past conditions will provide more reliable predictions.

Unfortunately, obtaining a sufficient match does not ensure that the history-matched parameter values (1) are representative of real-world properties, (2) are unique, because the data used for history matching is rarely sufficient to fully inform all aspects of the adjustable parameters, or (3) will provide the most conservative estimate of the prediction of interest (White and others, 2014). If the predictions of interest do not resemble the observation dataset, then history matching may do little to improve the reliability of predictions (Moore and Doherty, 2005). Therefore, calibration through history matching is generally a necessary step in the development of groundwater models, but it should not be considered the final product of the development of the model. Uncertainty quantification of the input parameters and model predictions is needed to supplement the history-matched best-fit parameter values. The best-fit parameter values are herein defined as those values that minimize the sum of squared differences (residuals) between the observation dataset and the model-simulated equivalents.

History matching, parameter uncertainty analysis, and predictive uncertainty analysis were completed with PEST (Doherty, 2005) and PEST++ (Welter and others, 2012), which are suites of model-independent, open-source, public-domain software that implement several parameter estimation and predictive uncertainty analysis algorithms. Use of this software, coupled with explicit mathematical regularization - the mathematical processes that help achieve numerical stability in the inverse problem and govern parameter plausibility and acceptability (Doherty and Hunt, 2010) - facilitates flexibility of the inverse problem to match the observation dataset while accommodating a large number of parameters. More importantly, a highly parameterized (Doherty and Hunt, 2010) approach to history matching facilitates robust uncertainty quantification because more uncertain model inputs are explicitly recognized and included in the analyses than would have been with few adjustable parameters (Voss, 2011a, 2011b). Before history matching, preprocessing for PEST was needed: (1) to determine parameterization in accordance with the model objectives and predictions of interest, (2) to process the observation dataset, and (3) to determine realistic expected values and ranges of parameters. The initial value and specified acceptable ranges of the adjustable parameters are considered part of the "prior," which is specification of expert knowledge in the parameter estimation process. Parameter ranges represent the 95-percent credible interval for each parameter.

\section{Parameterization}

Parameterization describes how uncertain model inputs are discretized in space and time in the history-matching process. The parameterization selected for this modeling analysis used a combination of pilot points (Doherty, 2003; Doherty and Hunt, 2010; Doherty and others, 2010a) and piece-wise zones of uniform property values (Hill and Tiedeman, 2007). Pilot points are a method of spatial parameter definition where hydraulic properties are assigned to a set of points distributed throughout the model domain rather than directly to the grid or mesh elements of a numerical model; property values are then assigned to model elements through spatial interpolation (Doherty, 2003). The selected parameterization recognized many more model inputs as uncertain when compared to previous models of the Edwards aquifer (Lindgren and others, 2004; Lindgren, 2006; Lindgren and others, 2011b). Pilot points were evenly distributed throughout the model domain, with a spacing of approximately 3.5 miles (fig. 11). The quantity of pilot points increased with depth in the model as the active extent of layers increase from layer 1 through layer 8 (fig. 8). The upper part of the Edwards aquifer (model layers 1-3) had 404 pilot points, the middle part of the Edwards aquifer (model layer 4) had 433 pilot points, and the lower part of the Edwards aquifer (model layers 5-8) had 454 pilot points. An anisotropic variogram (Isaaks and Srivastava 1989; Oliver and others, 2008) was used to distribute hydraulic conductivity from pilot points to the model grid and to incorporate apparent anisotropy in the calibrated spatial distribution of hydraulic conductivity obtained from Lindgren (2006) and the geostatistical analysis of Painter and others (2002). Use of an anisotropic variogram with pilot points is a more flexible application of expert knowledge compared to previous modeling efforts (Lindgren and others, 2004; Lindgren, 2006), and also respects the highly stochastic nature of the spatial distribution of hydraulic conductivity within the Edwards aquifer. The primary axis of anisotropy was specified as 50 degrees east of north, with an anisotropy ratio of 5.0 (Isaaks and Srivastava, 1989).

\section{Hydraulic and Transport Parameters}

Horizontal hydraulic conductivity for the upper and lower parts of the Edwards aquifer, vertical hydraulic conductivity for the middle part of the Edwards aquifer, and specific storage for the upper and lower parts of the Edwards aquifer (fig. 3) were adjusted during history matching by using multiplier pilot points (Dausman and others, 2010a). Instead of multipliers, the hydraulic characteristic (representative of fault hydraulic conductivity divided by fault width) of each horizontal-flow barrier within the Horizontal-Flow Barrier Package (HFB) (Harbaugh and others, 2000) was adjusted. The only solute transport-related parameters adjusted in the history-matching effort by using the BTN were multiplier pilot points for effective porosity for the upper and lower parts of the Edwards aquifer. During each forward model run, the multiplier pilot points are spatially interpolated to create arrays with the same dimension as the model input arrays. These interpolated arrays of multiplier values are then multiplied by the appropriate initial uniform property array, which resulted in updated arrays that were then either saved to file for direct use in the model or, for select properties, were further adjusted through the use of scaling parameters.

The selected parameterization was based on many trial iterations of parameterization and history matching. This iterative process indicated the need for dissolved-solids 


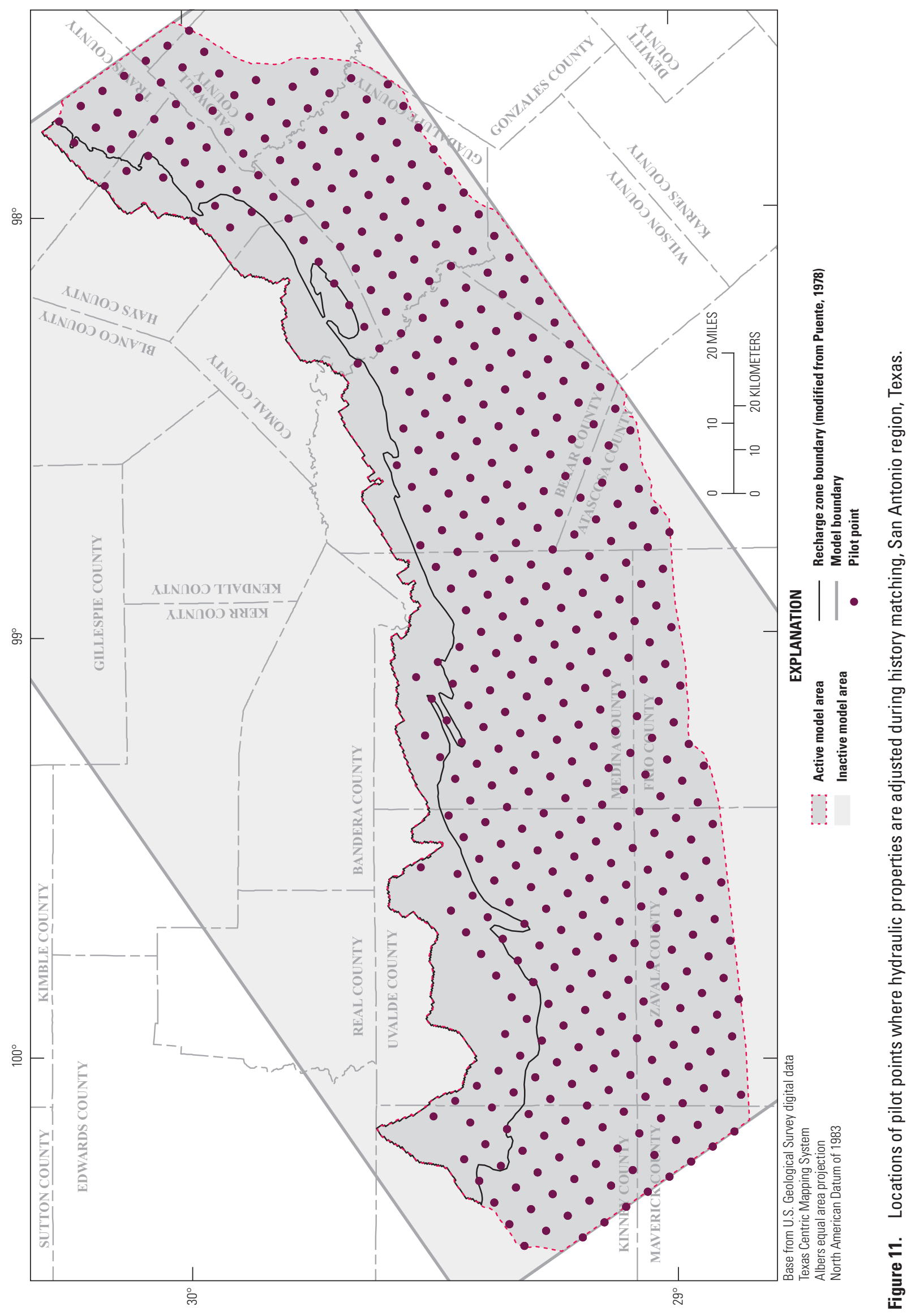


concentration threshold parameters and scaling parameters to best represent the hydraulic property variation associated with the different water-quality zones (fig. 4) of the Edwards aquifer. The updip extent of the transition zone is where mixing between fresh and saline water has caused formation of high-permeability, high-porosity preferential pathways of groundwater flow (Hovorka and others, 1998). The saline zone of the Edwards aquifer (fig. 4) is relatively stagnant compared to the freshwater zone, and thought to have relatively low permeability and porosity associated with largely unaltered carbonates (Deike, 1990; Groschen, 1994; Hovorka and others, 1998). To represent these relations in the history-matching effort, two threshold parameters were estimated, with each threshold parameter having three scaling parameters: hydraulic conductivity, specific storage, and effective porosity. The cumulative effect of this parameterization process is a flexible and automated property adjustment procedure that approximates the location of preferential flow pathways within the Edwards aquifer.

The first parameter (high_thresh) represents the dissolved-solids threshold concentration above which aquifer properties need to be scaled to be more representative of the area near the transition-zone interface where karstic alteration has developed high-permeability, high-porosity preferential flow areas. For dissolved-solids concentrations greater than high_thresh, the hydraulic conductivity, specific storage, and effective porosity need to be scaled up, that is, increased by multiplying by a scaling factor greater than 1.0. Because little knowledge exists about the exact nature of this complex process, the concentration where this threshold occurs was treated as an adjustable parameter in history matching so that the bestfit value could be informed by the observation dataset. The best-fit value of high_thresh was $329 \mathrm{mg} / \mathrm{L}$ and the associated scaling parameters for hydraulic conductivity, specific storage, and effective porosity were $1.5,1.7$, and 2.0 , respectively. These best-fit scaling parameters indicate that more groundwater needs to be transmitted through the transition zone (higher hydraulic conductivity) at a lower advective velocity (higher effective porosity). The second threshold parameter (low_thresh) represents the dissolved-solids threshold concentration above which hydraulic conductivity, specific storage, and effective porosity need to be scaled down to be more representative of the unaltered, lower permeability, lower porosity saline zone. The best-fit value of low_thresh was $2,074 \mathrm{mg} / \mathrm{L}$ and the associated scaling parameters for hydraulic conductivity, specific storage, and effective porosity were $0.0011,0.001$, and 0.75 . The saline-zone scaling parameters indicate that less groundwater needs to be transmitted in the unaltered saline part of the Edwards aquifer. Implementation of this concentration-based parameterization allows for the flexibility of inclusion of additional expert knowledge of the aquifer in history matching, which effectively supplements the sparse transition and saline-zone observation dataset. Furthermore, the best-fit estimates of these threshold parameters and scaling parameters are consistent with the hydrogeologic and geochemical understanding of the existence of preferential-flow areas near the "bad-water line" of 1,000 mg/L dissolved-solids (which falls within the range of high_thresh to low_thresh estimates of 329 to $2,074 \mathrm{mg} / \mathrm{L})$.

The initial spatial distribution of hydraulic (horizontal hydraulic conductivity, vertical hydraulic conductivity, and specific storage) and transport (effective porosity) properties in the model domain were specified as uniform and, where applicable, were assigned an initial value that is the mean of the associated calibrated spatial property distribution from previous models (Lindgren and others, 2004; Lindgren, 2006). Lower and upper bounds of the 95-percent credible interval of each parameter were used to set the range of potential values, which allows the parameter values maximum flexibility within a range of values based on expert knowledge.

The horizontal hydraulic conductivity pilot points (Doherty, 2003; Doherty and Hunt, 2010; Doherty and others, 2010a) for the upper and lower parts of the Edwards aquifer and the vertical hydraulic conductivity pilot points for the middle part of the Edwards aquifer were adjusted during the history-matching effort to better reproduce the observation dataset. The initial values of these multiplier pilot points were 1 , and the prior 95-percent credible interval of these multiplier pilot points ranged from $1.0 \times 10^{-5}$ to $1.0 \times 10^{5}$. The initial spatial distribution of horizontal hydraulic conductivity for the upper and lower parts of the Edwards aquifer was a uniform value of 1,500 ft/day based on the average hydraulic conductivity from the calibrated model of Lindgren (2006). The initial spatial distribution of vertical hydraulic conductivity for the middle part of the Edwards aquifer was a uniform value of $3.0 \mathrm{ft} /$ day based on the lower bound of the range of calibrated hydraulic conductivity values in Lindgren (2006). The best-fit horizontal hydraulic conductivity (fig. $12 \mathrm{~A}$ and $12 \mathrm{C}$ ) distributions for the upper and lower parts of the Edwards aquifer (including the concentration threshold scaling) and the best-fit vertical hydraulic conductivity (fig. 12B) distribution of the middle part of the Edwards aquifer indicate considerable spatial variability in best-fit values of conductivities needed for history matching. In general, hydraulic conductivities are smaller farther downdip in the model as expected. Also, although vertical hydraulic conductivities of the middle part of the Edwards aquifer are smaller than horizontal hydraulic conductivities of the upper and lower parts of the Edwards aquifer, spatial variability still exists.

As the model is a fully confined approximation of the Edwards aquifer, the specific storage parameters control storage changes in the aquifer. Specific storage multiplier pilot points were adjusted for the upper and lower parts of the Edwards aquifer, and the initial value of the specific storage distribution was $1.1 \times 10^{-6} 1 / \mathrm{ft}$ and was uniform. The initial value of all specific storage multiplier pilot points was 1 , and the prior 95-percent credible interval of these multiplier pilot points allowed specific storage to range from $1.0 \times 10^{-9} 1 / \mathrm{ft}$ to $1.0 \times 10^{-4} 1 / \mathrm{ft}$. The best-fit specific storage distributions for the upper and lower parts of the Edwards aquifer (fig. 13), which include the concentration threshold scaling, indicate considerable spatial variability in values of specific storage, with 

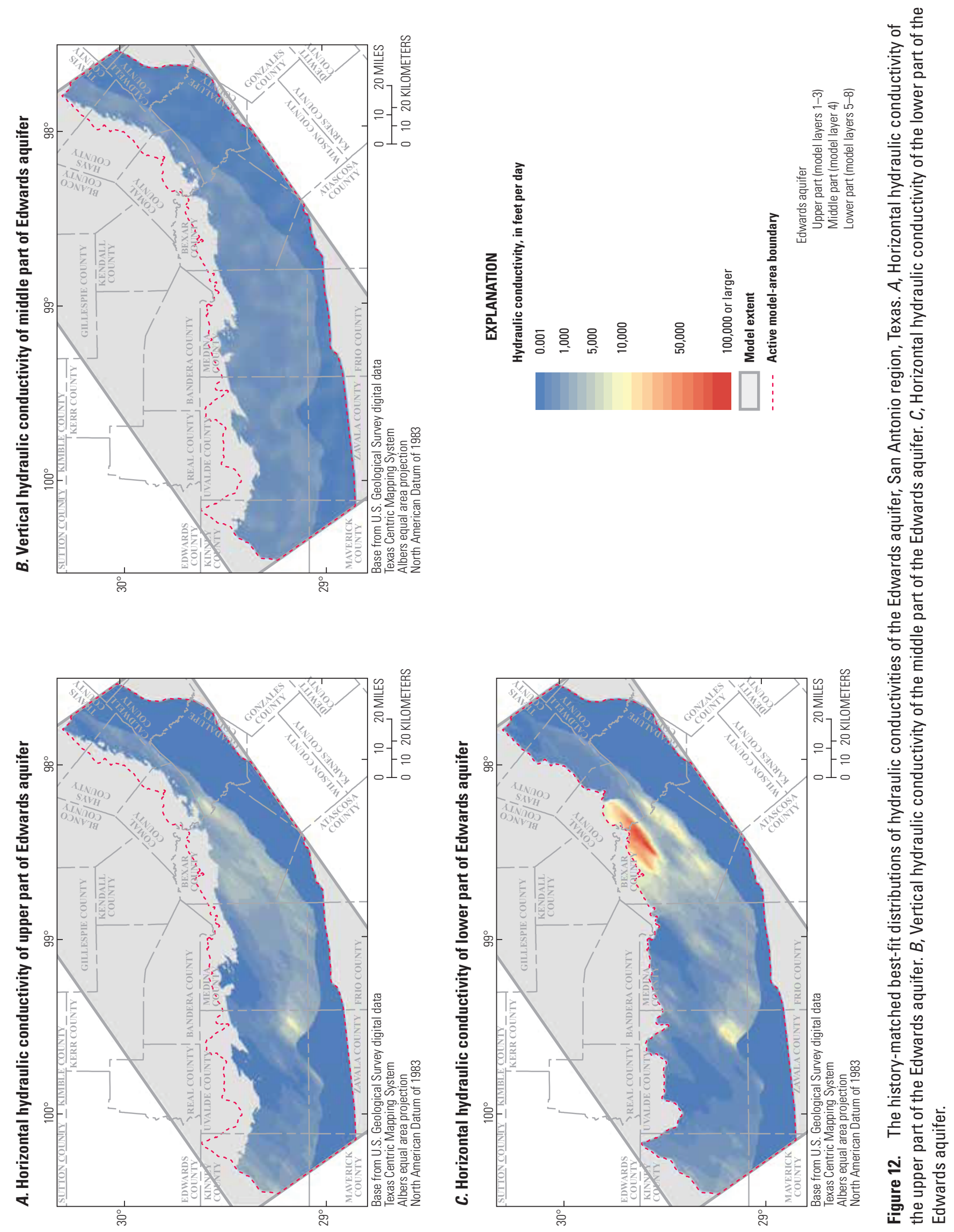
the highest values occurring in the recharge zone (fig. 13B) in Kinney and Uvalde counties. The specific storage for the middle part of the Edwards aquifer was not used as an adjustable parameter and was specified as a uniform value of $1.1 \times$ $10^{-6} 1 / \mathrm{ft}$.

The hydraulic effect of faults within the Edwards aquifer is pronounced but uncertain; some faults are believed to be barriers to flow, whereas others are believed to concentrate flow preferentially (Groschen, 1994; Hovorka and others, 1998). In recognition of this uncertainty, the hydraulic characteristic of each of the HFB-simulated faults (same as those included in the diffuse-flow model [Lindgren, 2006]) was adjusted during the history-matching process. The historymatched HFB hydraulic characteristic value of Lindgren (2006) for each fault was used as the initial value in this analysis. The prior 95-percent credible interval of possible hydraulic characteristic values was specified to reflect unknown specifics of any fault; therefore, values were allowed to range from 0 to $1.0 \times 10^{10}$ per day. The best-fit HFB hydraulic characteristic values ranged from 0 to 10,430 per day.

Effective porosity multiplier pilot points were adjusted for the upper and lower parts of the Edwards aquifer. The initial value of the effective porosity distribution was 0.25 and was uniform. The initial value of all effective porosity multiplier pilot points was 1 , and the prior 95-percent credible interval of these multiplier pilot points allowed effective porosity to range from 0.025 to 0.5 ( 2.5 percent to 50 percent). The best-fit effective porosity (fig. 14) distributions for the upper and lower parts of the Edwards aquifer, which include the effects of the dissolved-solids concentration threshold scaling parameters, indicate considerable spatial variability within the aquifer. The highest values of effective porosity are within the updip area of the transition zone (fig. 4) where the application of the high_thresh scaling parameter has increased the values (fig. 14). The effective porosity for the middle part of the Edwards aquifer was specified a uniform value of 0.25 as the effective porosity of this layer was assumed to minimally affect solute transport ( 0.25 is representative of the mean of the prior).

\section{Model Sources and Sinks}

The terms "model sources" and "model sinks" respectively refer to the model boundary conditions that control water entering and leaving the aquifer. Including these boundary condition elements in the history matching process is important because these elements strongly affect the model simulated results and are largely uncertain. Groundwater recharge is a primary model source. The selected recharge parameterization attempts to characterize several sources of recharge uncertainty. The USGS has published monthly recharge estimates for the Edwards aquifer that are distributed across surface-water basins (Lindgren and others, 2004; Lindgren, 2006; Slattery, 2004). These estimates were prepared using the best available information; nevertheless, the estimates are uncertain, largely as a result of the complex and transient nature of recharge within the highly karstified Edwards aquifer. To represent the uncertainty of recharge within the history-matching effort, the recharge parameterization included two distinct sets of parameters that were used in sequence. The result of this parameterization was used to build a $\mathrm{RCH}$ for input into the model.

The first set of recharge parameters were scaling parameters that were applied to each surface-water basin (fig. 15) that overlies the outcrop of the Edwards aquifer. These parameters corresponded to individual basins within the recharge zone from Lindgren (2006). These scaling parameters were assigned to either a wetter month when rainfall is higher than average (April-June, September-November) or drier month when rainfall is less than average (January-March, July, August, December) (Larkin and Bomar, 1983). The initial value of all month-dependent recharge multiplier parameters was 1 , and the prior 95-percent credible bounds of the multipliers ranged from 0.25 to 1.75 . The best-fit wetter and drier month surface-water basin recharge multipliers (fig. 15) indicate that multipliers for individual surface-water basins are quite different between the wetter and drier months. Decreases in recharge are seen in the red color range and increases in recharge are seen in the blue color range.

The second set of recharge parameters attempted to capture the potential for annual variability in recharge estimates by using a global scaling parameter for each calendar year from 1999 through 2009. That is, for each year in the model simulation period, a single multiplier parameter was applied to the input recharge arrays for each simulated month in that year. The initial value of all annual recharge multiplier parameters was 1 , and the prior 95-percent credible bounds of the multipliers ranged from 0.25 to 1.75 . The best-fit annual recharge scaling parameters indicate considerable variability from year to year with no discernable pattern (fig. 16).

In addition to recharge originating from precipitation, groundwater flow (flux) into the Edwards aquifer from the underlying Trinity aquifer (figs. 2-3) may also be a substantial model source, especially during drought conditions; however, the magnitude and spatial distribution of this flux is highly uncertain (Wong and others, 2013). The calibrated spatial distribution of the Trinity aquifer flux from Lindgren (2006) was used as the initial flux for this modeling effort. To capture this source of uncertainty in the history-matching process, the Trinity aquifer flux was scaled by a group of multiplier parameters. These multiplier parameters consisted of cells of the Trinity aquifer flux grouped into 10 zones. This parameterization provided the ability to spatially adjust the Trinity aquifer flux during history matching. The Trinity aquifer flux from Lindgren (2006) was scaled by the multiplier parameters before being used by the model in each forward run. The initial value of all Trinity aquifer flux multiplier parameters was 1 , and the prior 95-percent credible interval bounds of the multipliers ranged from 0.01 to 100 . Flux from the Trinity aquifer into the Edwards aquifer is represented in model layer 8 (fig. 5) at the northern boundary of the active model area. The best-fit spatial distribution of Trinity aquifer flux 
A. Specific storage of upper part of Edwards aquifer

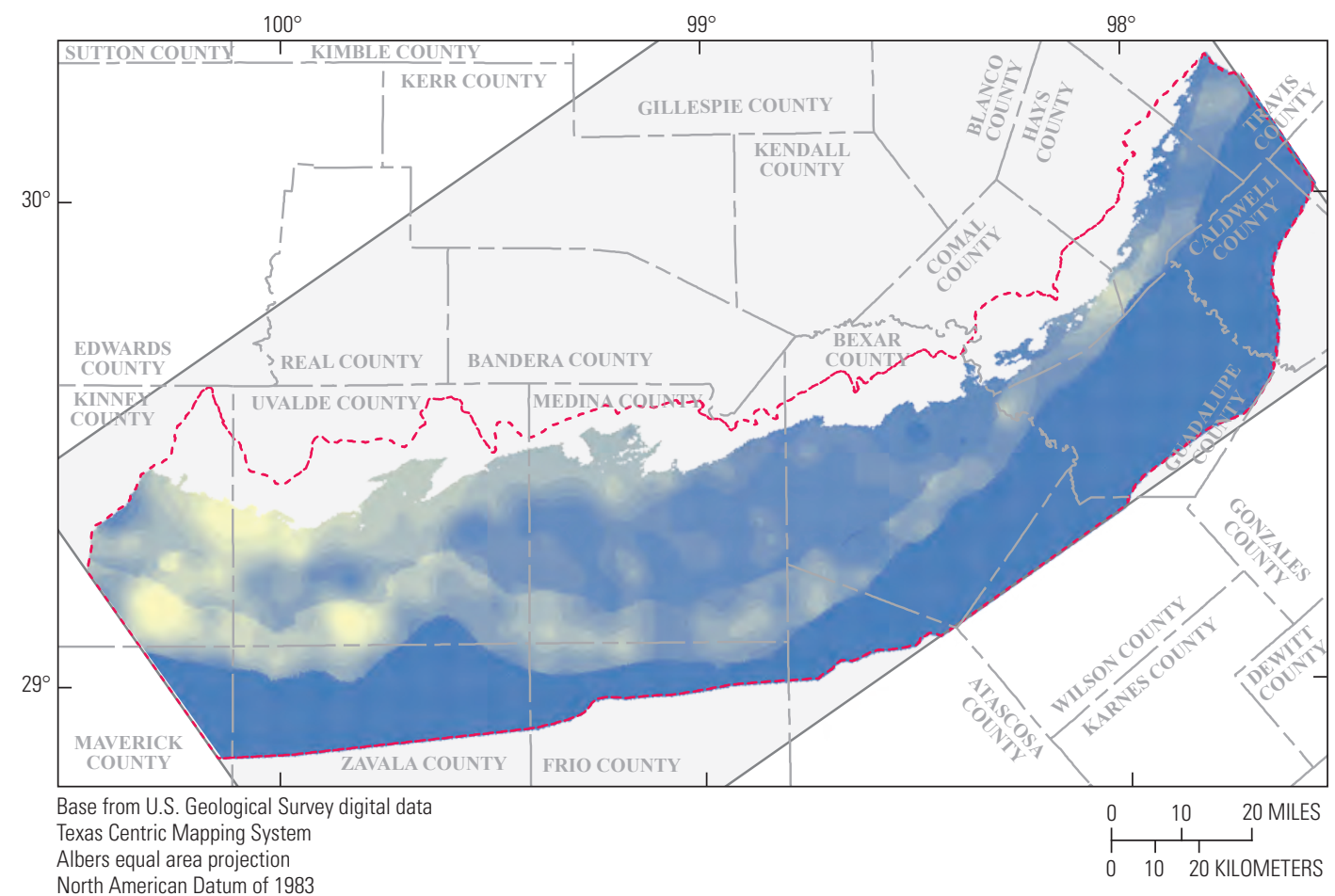

\section{EXPLANATION \\ Specific storage of upper part (model layers 1-3) of Edwards aquifer, in per foot \\ Less than 0.0000007 \\ 0.000005 \\ 0.000001 \\ 0.00005 \\ 0.0001}

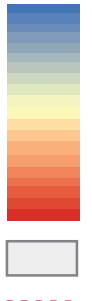

Model extent

Active model-area boundary

\section{B. Specific storage of lower part of Edwards aquifer}

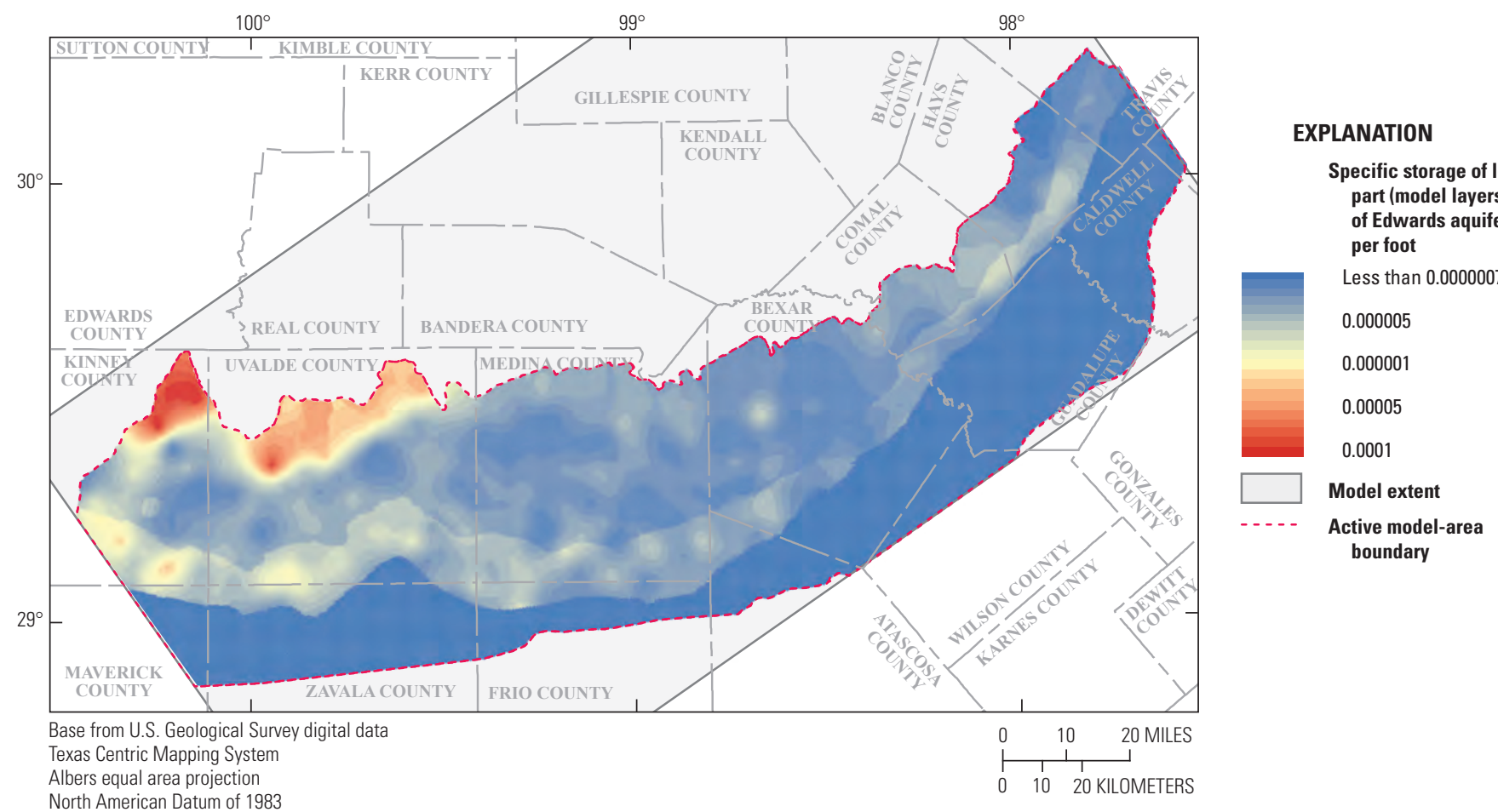

Figure 13. The history-matched best-fit distributions of specific storage of the Edwards aquifer, San Antonio region, Texas for $A$, the upper part of the Edwards aquifer, and $B$, the lower part of the Edwards aquifer. 


\section{A. Effective porosity of upper part of Edwards aquifer}
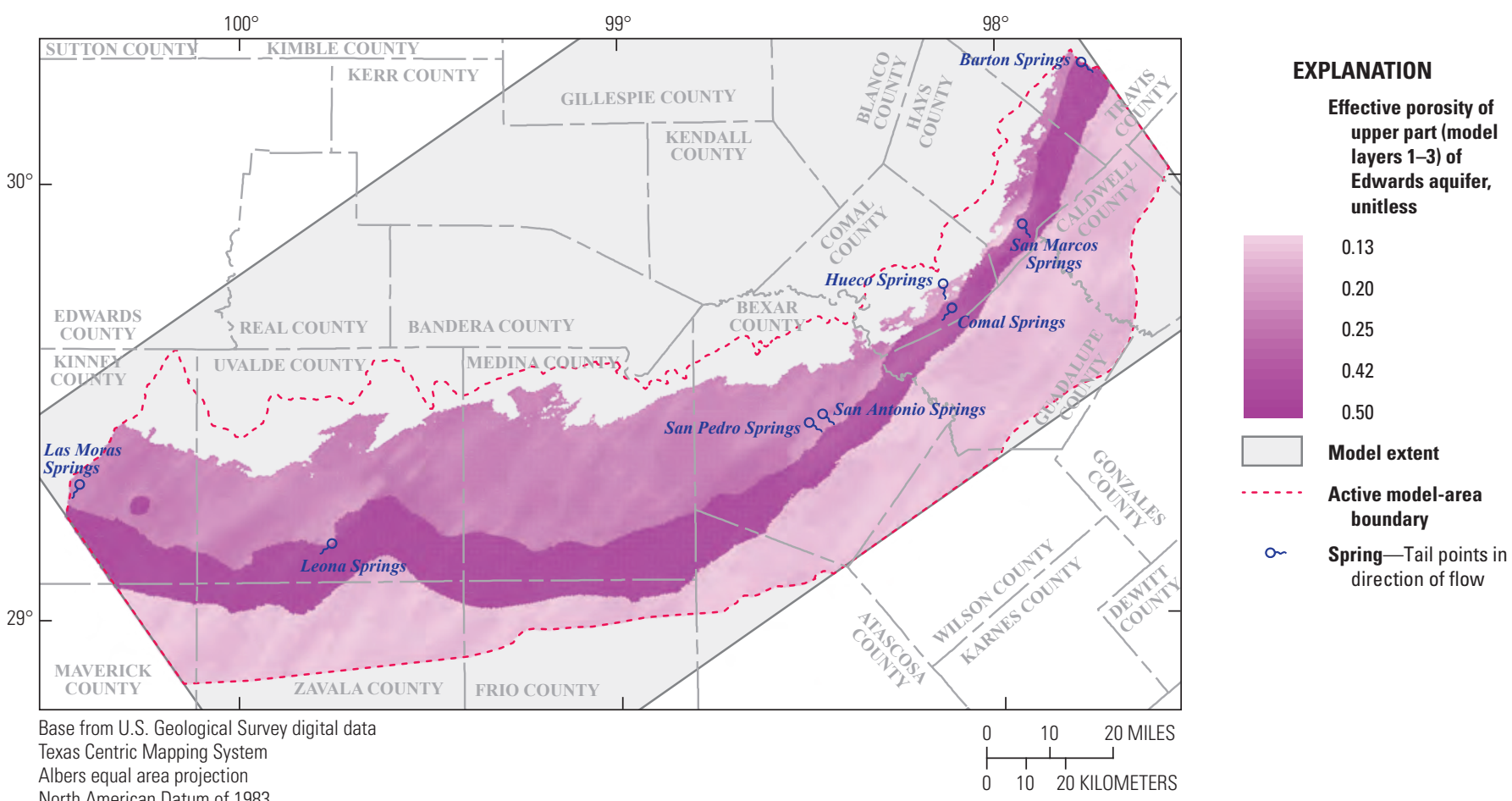

\section{B. Effective porosity of lower part of Edwards aquifer}
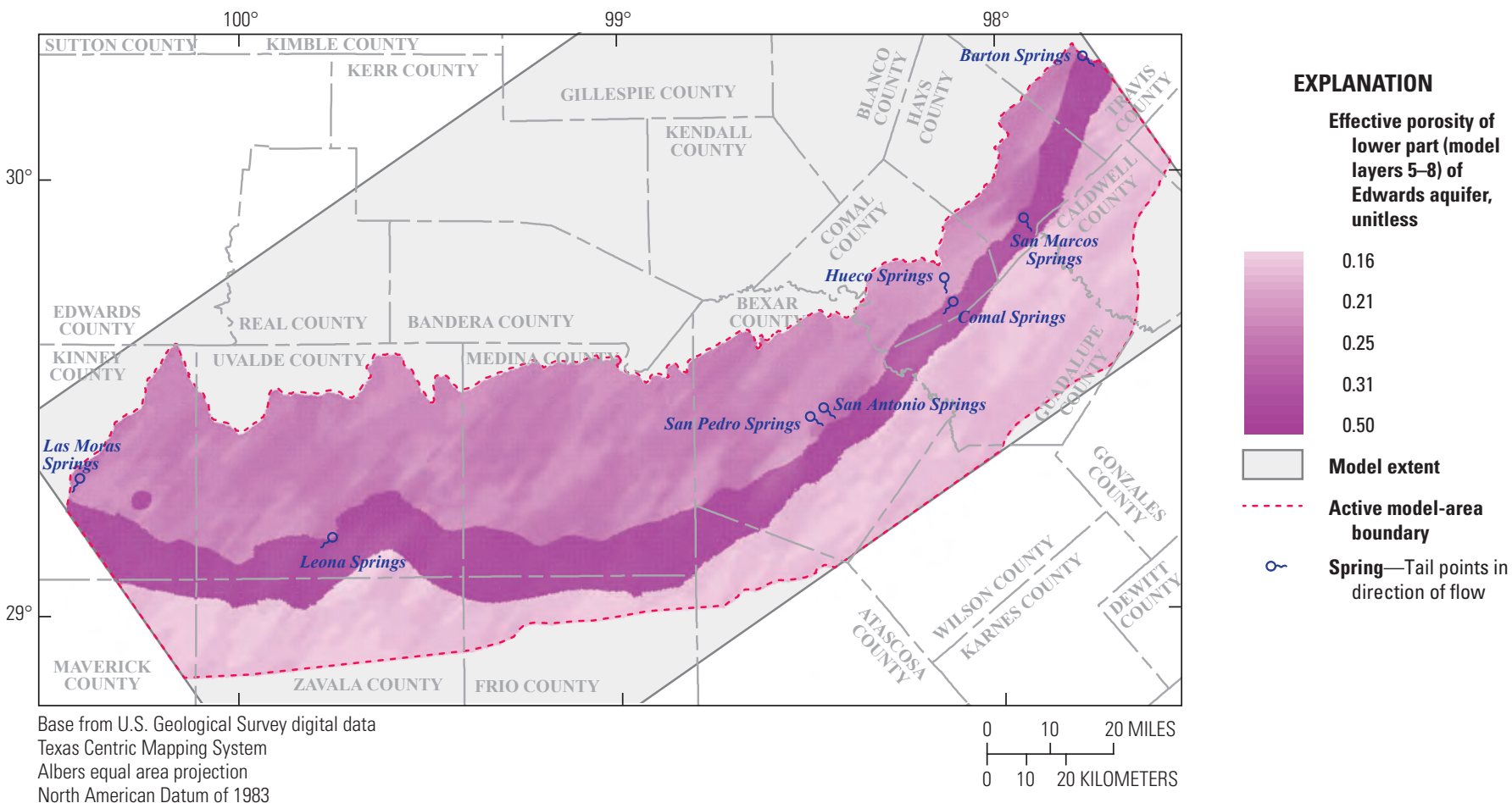

Figure 14. The history-matched best-fit distributions of effective porosity of the Edwards aquifer, San Antonio region, Texas for $A$, the upper part of the Edwards aquifer, and $B$, the lower part of the Edwards aquifer. 


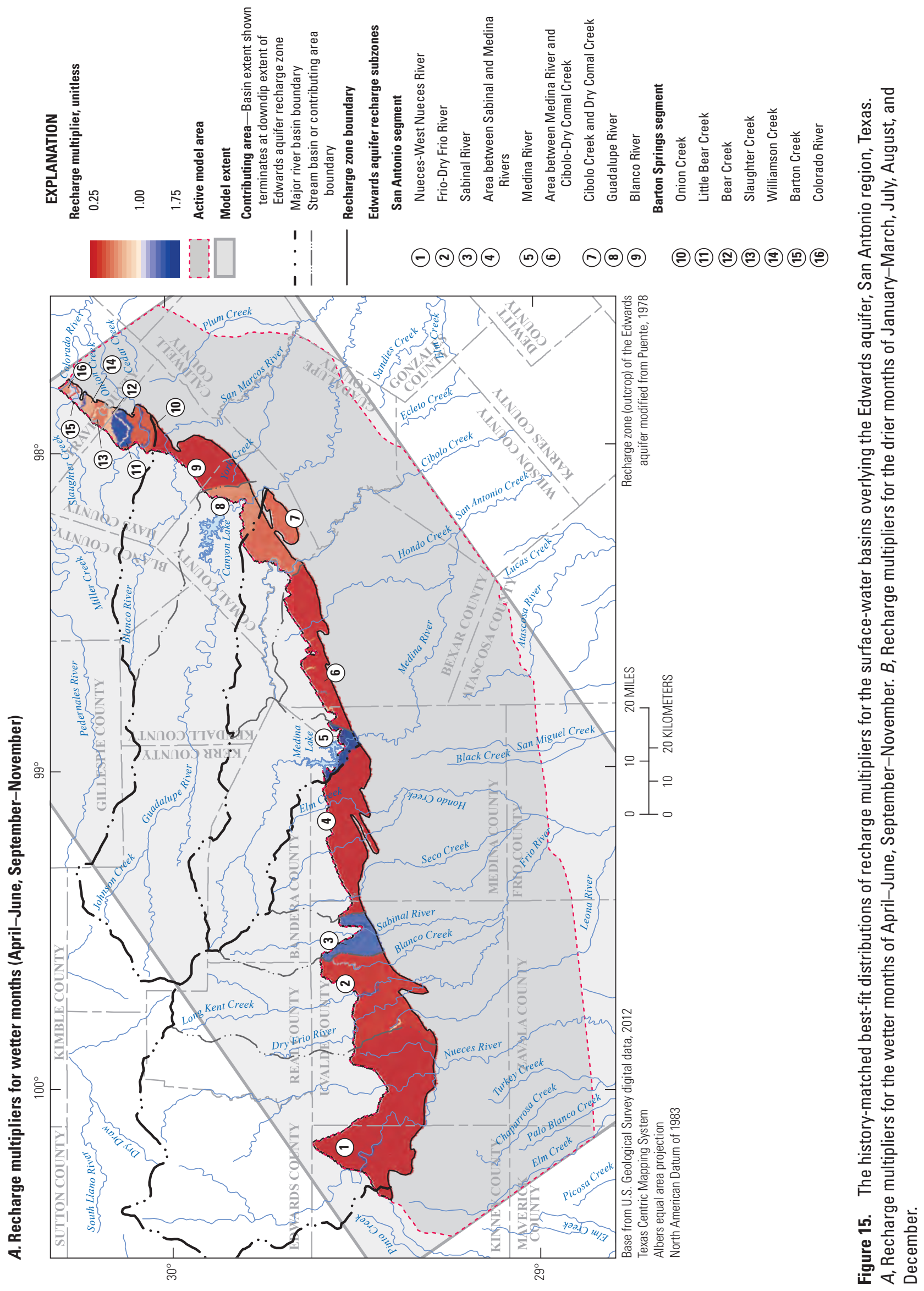




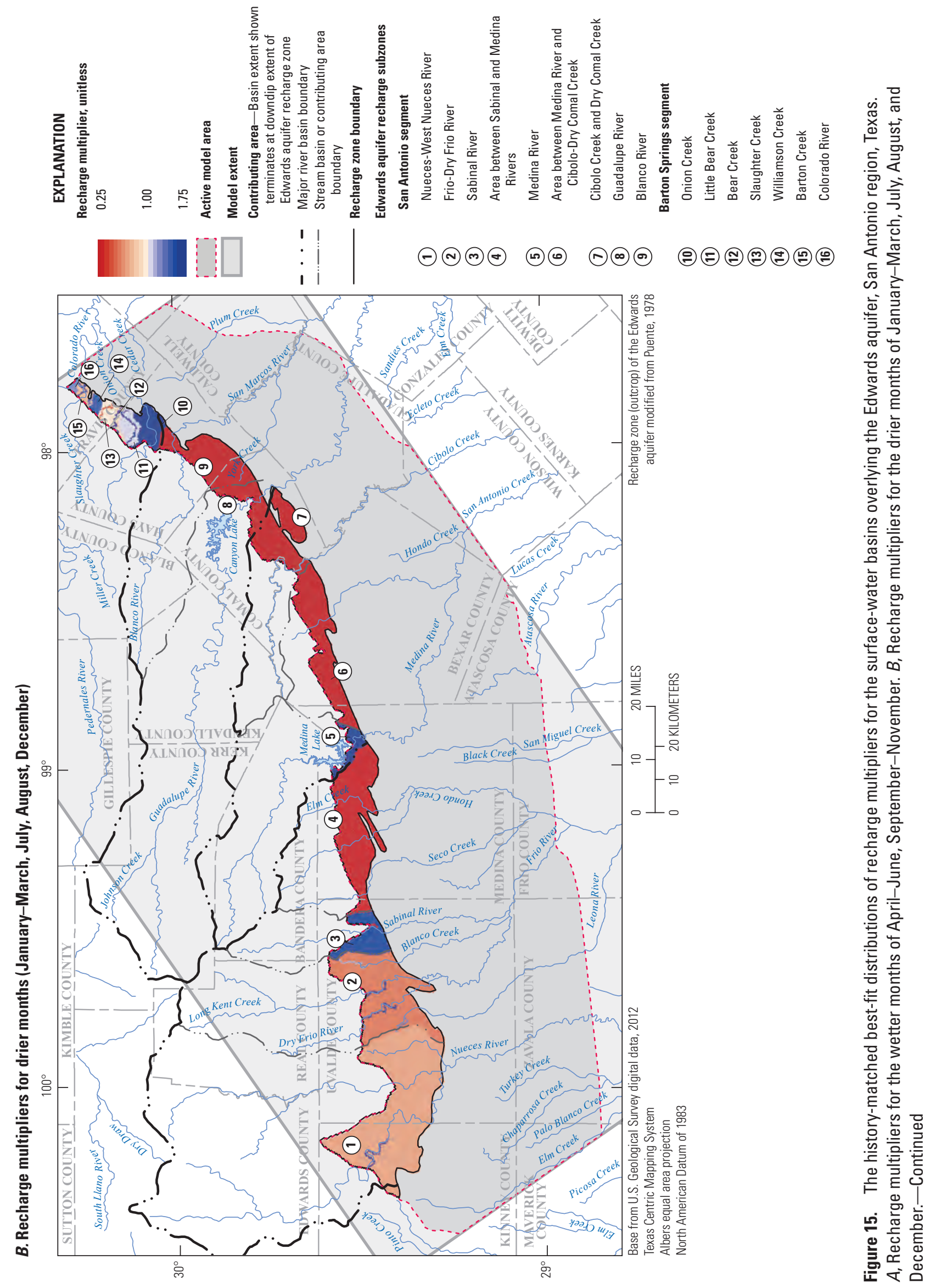




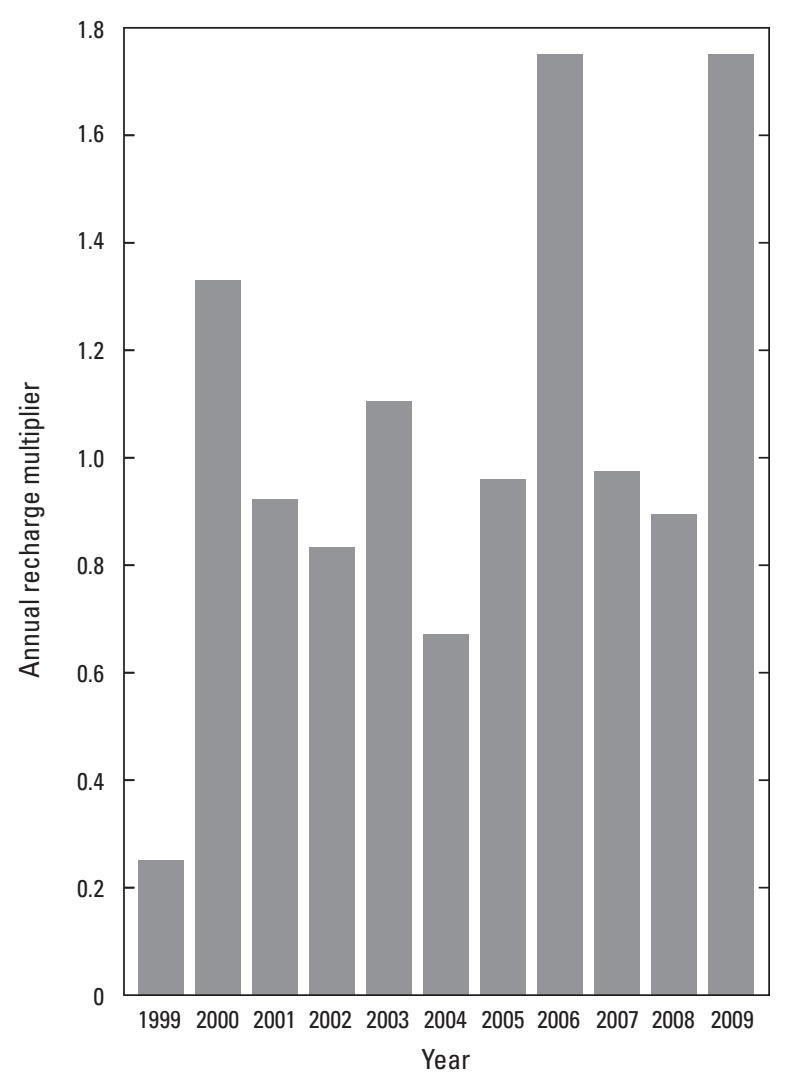

Figure 16. The history-matched best-fit annual recharge multipliers, 1999-2009.

(fig. 17B) displays more variability when compared to the initial spatial distribution of Trinity aquifer flux (which is the same as the flux from Lindgren, 2006) (fig. 17A).

Springs are major model sinks where water flows out of the Edwards aquifer (table 1). For modeling purposes, springs were represented as outflow (drain) features, which is a gross simplification of these complex hydrologic features. As a result of this simplification, the model inputs associated with these boundary conditions are uncertain. Thus, the drain conductance and altitude for each spring in DRN of the model were adjusted during history matching. The calibrated values for drain conductance and altitude (table 11 of Lindgren and others, 2004, p. 131) were used as initial values in this modeling analysis. The prior 95-percent credible interval for the drain conductance parameters ranged from 0 to $1.0 \times 10^{10}$ feet squared per day ( $\mathrm{ft}^{2} /$ day). The lower bound of the prior 95-percent credible interval for the drain altitude parameters was set at the altitude of the bottom of the model cell that contained the drain; the upper bound was $1.0 \times 10^{10} \mathrm{ft}$ above National Geodetic Vertical Datum of 1929 (NGVD 29). The best-fit drain conductance and drain altitude values for Leona, San Pedro, San Antonio, Comal, San Marcos, and Barton Springs (table 1) are similar to calibrated values for these springs from previous models (Lindgren and others, 2004; Lindgren, 2006). The best-fit drain conductance for this model for Las Moras Springs was two orders of magnitude higher than for the model of Lindgren and others (2004), but this spring is near the active model boundary in the western part of the model area and data from this spring were not used for history matching.

Table 1. The history-matched best-fit Drain (DRN) package altitude and conductance parameters that control spring discharge from the model, San Antonio region, Texas.

[DRN, MODFLOW Drain Package; ft, feet; NGVD, National Geodetic Vertical Datum of 1929 ; $\mathrm{ft}^{2} /$ day, feet squared per day]

\begin{tabular}{lcr}
\hline $\begin{array}{c}\text { Springs in the San } \\
\text { Antonio region (fig. 1) }\end{array}$ & $\begin{array}{c}\text { DRN Altitude, ft above } \\
\text { NGVD 29 }\end{array}$ & $\begin{array}{r}\text { DRN Conduc- } \\
\text { tance, } \mathbf{f t}^{2} / \mathbf{d a y}\end{array}$ \\
\hline Las Moras Springs & 1,009 & $104,626,550$ \\
Leona Springs & 799 & 142,869 \\
San Pedro Springs & 684 & 216,845 \\
San Antonio Springs & 664 & 726,731 \\
Comal Springs & 558 & $5,139,129$ \\
San Marcos Springs & 551 & $4,701,207$ \\
Barton Springs & 403 & $2,160,535$ \\
\hline
\end{tabular}

Initial Dissolved-Solids Concentrations

As explained in the "History-Matching Phase-Initial Conditions-Initial Dissolved-Solids Concentrations" section of this report, initial dissolved-solids concentrations were based on water-quality and geophysical log data, and a relatively large amount of dissolved-solids concentration data exist for the freshwater zone when compared to the sparse amount of dissolved-solids concentration data for the transition and saline zones (fig. 9). Because of this disparity and the associated uncertainty, the initial dissolved-solids concentration distribution was parameterized and adjusted through use of pilot points of initial concentration multipliers for the upper, middle, and lower parts of the Edwards aquifer. As the initial concentrations were adjusted, the concentration assigned to the southern specified-concentration boundary condition was also automatically adjusted to account for the uncertainty in the specification of this boundary condition (fig. 18). The bestfit initial dissolved-solids concentration distributions for the upper, middle, and lower parts of the Edwards aquifer indicate some changes with depth (such as in Frio County in the lower part of the Edwards aquifer) where the observation dataset has informed the initial concentrations. However, in general, the initial concentrations were similar between the upper, middle, and lower parts of the Edwards aquifer because there was not enough information in the observation dataset to uniquely estimate the initial concentrations in the different parts of the aquifer (fig. 18).

\section{Historical Observation Dataset}

More than 8,000 observations were used for history matching; data consisted of groundwater heads, spring discharge, dissolved-solids concentrations, and dissolved-solids 


\section{A. Initial Trinity aquifer flux into the overlying Edwards aquifer}

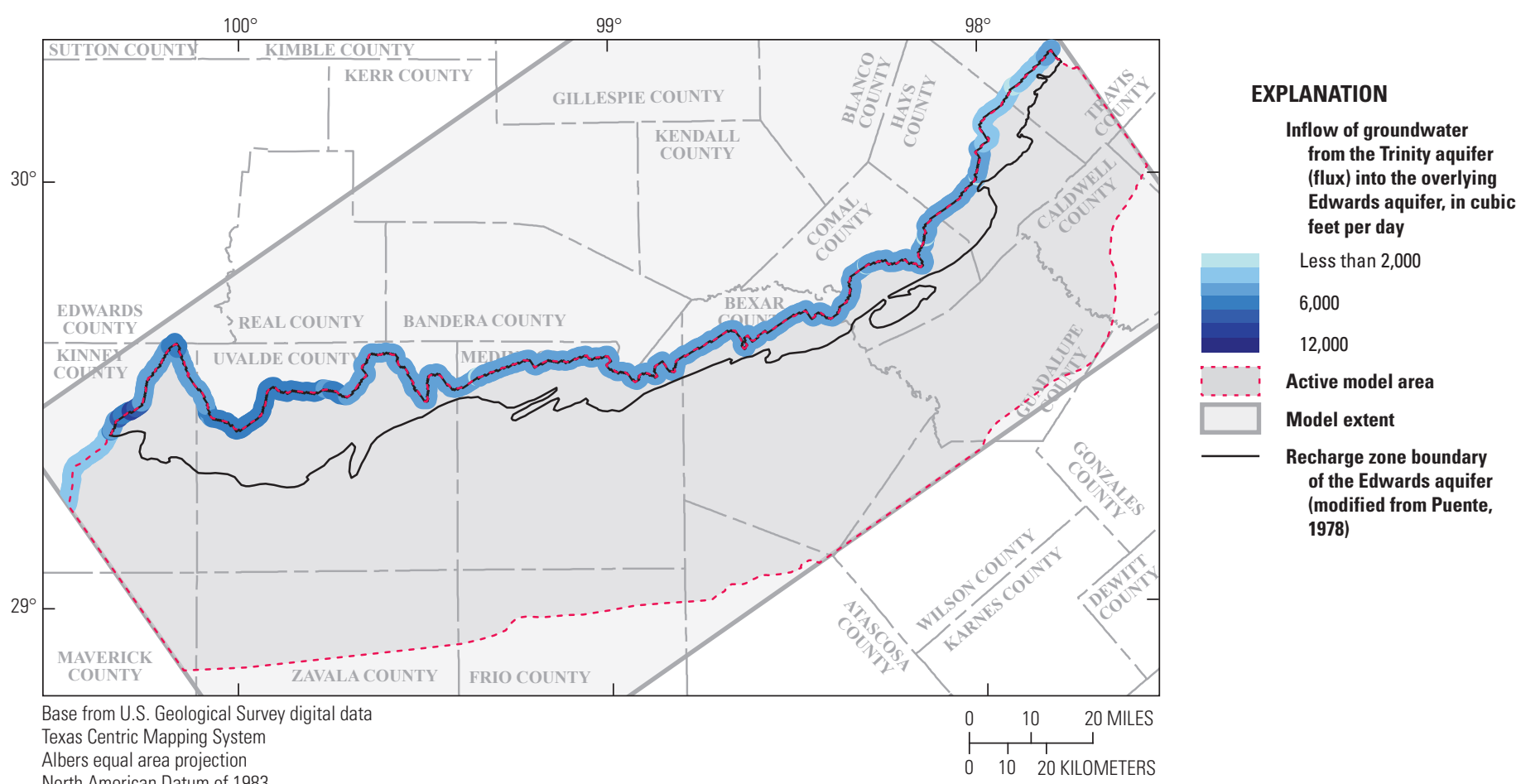

\section{B. History-matched best-fit Trinity aquifer flux into the overlying Edwards aquifer}

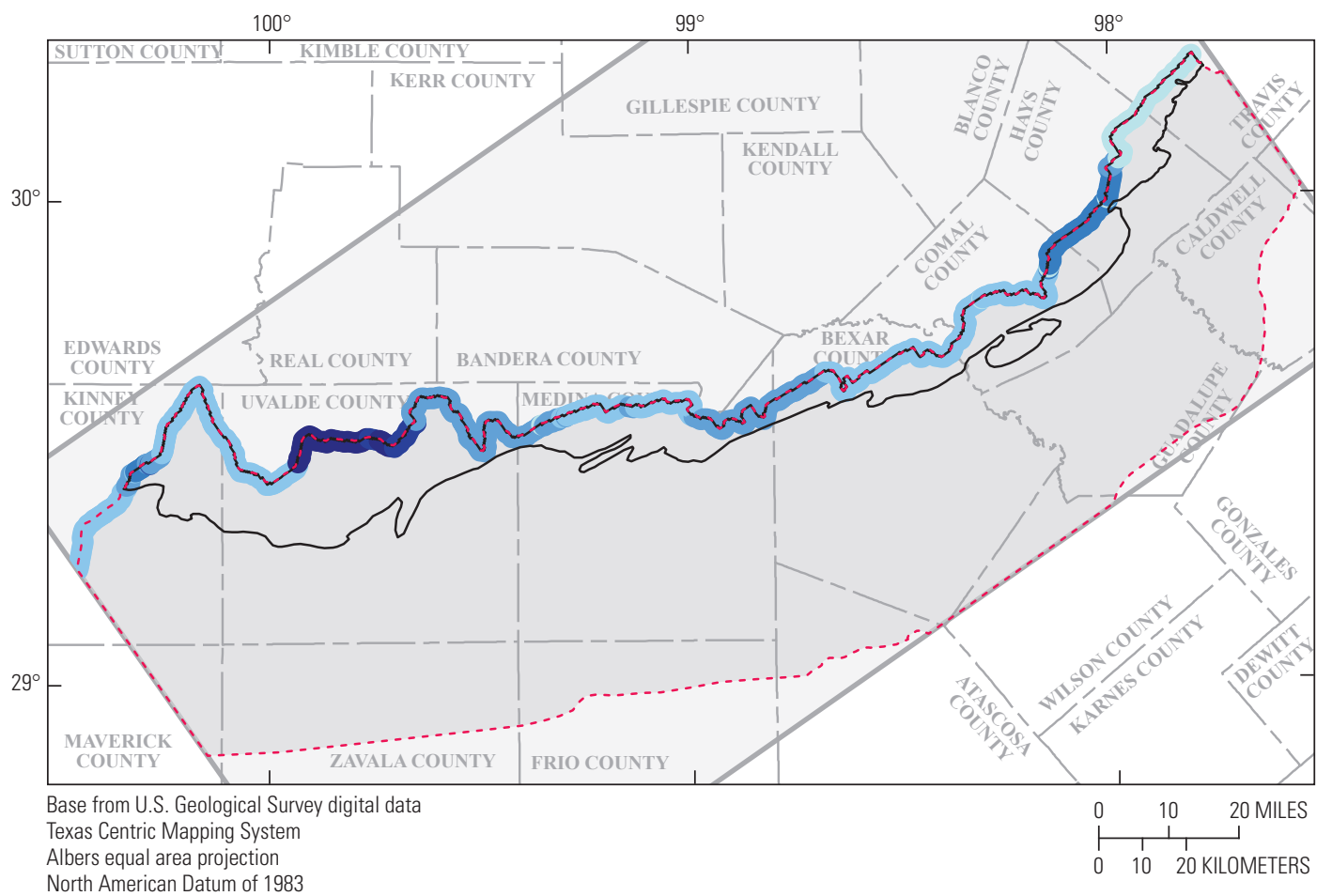

Figure 17. Inflow of groundwater from the Trinity aquifer (flux) into the overlying Edwards aquifer, San Antonio region, Texas. A, Initial flux. $B$, History-matched best-fit flux. 

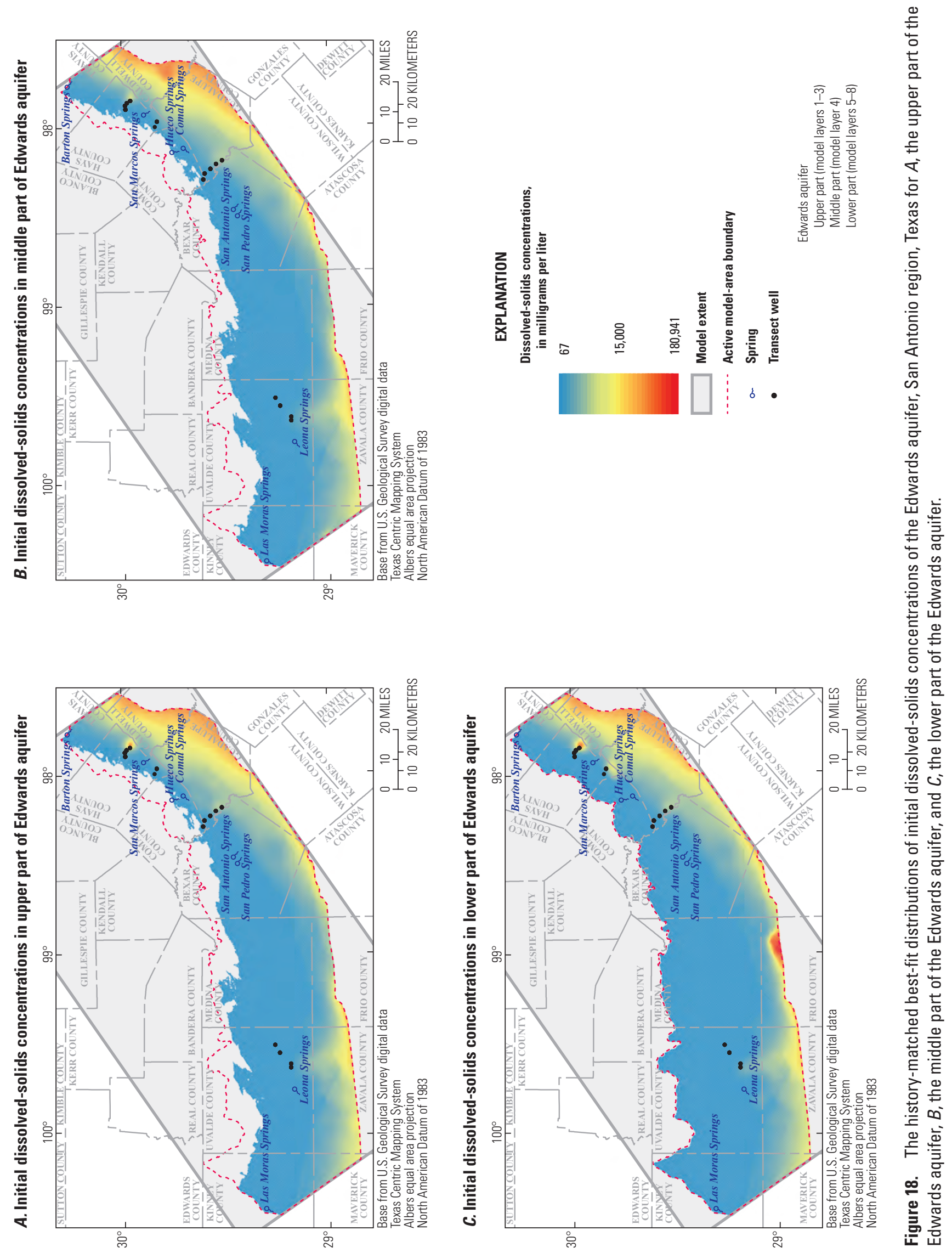
mass constraints at withdrawal (production) wells (where mass refers to the solute mass) (fig. 19). Annual total discharge volumes of the five history-matched springs in the model (Leona, San Pedro, San Antonio, Comal, and San Marcos) were also used for history matching.

The dissolved-solids mass constraints represent the observation that production wells, or withdrawal wells, in the Edwards aquifer do not produce poor-quality (high dissolvedsolids concentration) water. These constraints were formulated so that the total mass of dissolved solids for a given well was equal to the specified freshwater dissolved-solids concentration of the Edwards aquifer times the volume of water extracted from the well during the model simulation period.

Observation weights were subjectively specified to guide the history-matching process to reproduce the observations that most resemble the model predictions. As explained by Doherty and Welter (2010, p. 2) "subjective decisions must then be made on weighting schemes to apply to the calibration data set when fitting model outputs to that data set in order to estimate parameters. As estimated parameter values depend on these decisions, these estimates, as well as assessments made of the uncertainty associated with these estimates, inherit a subjective component." The observation weights were specified so that the composite, weighted objective function-a function of residuals (differences between observations and model-simulated equivalents) — at the start of the historymatching process was composed of an equal contribution from each of the following types of observations:

1. Groundwater-head time series for well J-17;

2. Remaining groundwater-head time series at another 192 wells;

3. Spring discharge time series for Comal and San Marcos Springs;

4. Remaining spring discharge time series for Leona, San Pedro, and San Antonio Springs;

5. Total annual discharge volumes for Comal and San Marcos Springs;

6. Remaining total annual discharge volumes for Leona, San Pedro, and San Antonio Springs;

7. Total mass of dissolved-solids (mass constraints) for production wells, and

8. Dissolved-solids concentration data.

\section{Groundwater Head Observations}

Groundwater heads for wells within the active model domain $(4,232$ head observations, fig. 19, 20A) for the period of 1999-2009 were used for history matching. Well construction information was used, when available, to assign heads to distinct layers instead of using the well depth. Well J-17 was more heavily weighted because it is the focus of regulatory scrutiny and heads measured at this well are known to be statistically correlated with discharge at Comal Springs (Miller and Long, 2006).

\section{Spring Discharge Observations}

Five major springs were used for history matching: Leona, San Pedro, San Antonio, Comal, and San Marcos Springs (fig. 19, 20B). Comal and San Marcos Springs were more heavily weighted because predictions will be made at these springs and because the discharge at these two springs is important for ecological and recreational purposes. Total annual discharge volumes for each of the five springs were calculated from the spring discharge series and were used as an additional data type in the observation dataset during history matching. A total of 636 spring discharge observations and 55 total annual volume observations were included in the observation dataset.

\section{Dissolved-Solids Concentration}

Each dissolved-solids concentration observation (693 observations) (fig. 19, 20C) was included in history matching; each observation was used twice, with different weights applied to each observation as part of a standard and inverseweighting process. One standard weight was assigned proportional to the magnitude of the concentration, whereas the other was assigned inversely proportional to the magnitude of the concentration. Including the inverse-weighted concentration observations ensures that the history-matching effort appropriately takes into account low dissolved-solids concentrations that would otherwise be masked by large dissolved-solids concentrations. A total of 693 standard-weighted and 693 inverse-weighted dissolved-solids concentration observations were included in the observation dataset.

\section{Constraints on Total Mass of Dissolved Solids at Production Wells}

Constraints on the total mass of dissolved solids removed from water from withdrawal (production) wells (fig. 19) were specified to minimize the extraction of water with concentrations above $325 \mathrm{mg} / \mathrm{L}$ (the background freshwater concentration), because simulated wells should not be withdrawing brackish or saline water. For each simulated stress period, the volume of water withdrawn at a production well was multiplied by the simulated dissolved-solids concentration in the same model cell. These values are then summed for all stress periods. This calculation yields a total mass of dissolved solids removed by each production well. The "observed" value for each production well is the product of the background concentration times the total volume extracted from each well, effectively enforcing a condition that only freshwater exists at production wells. Formulation of these types of constraints is valid because the only source of dissolved solids in the model originates from the saline zone. A total of 1,973 mass constraints were included in the observation dataset. 


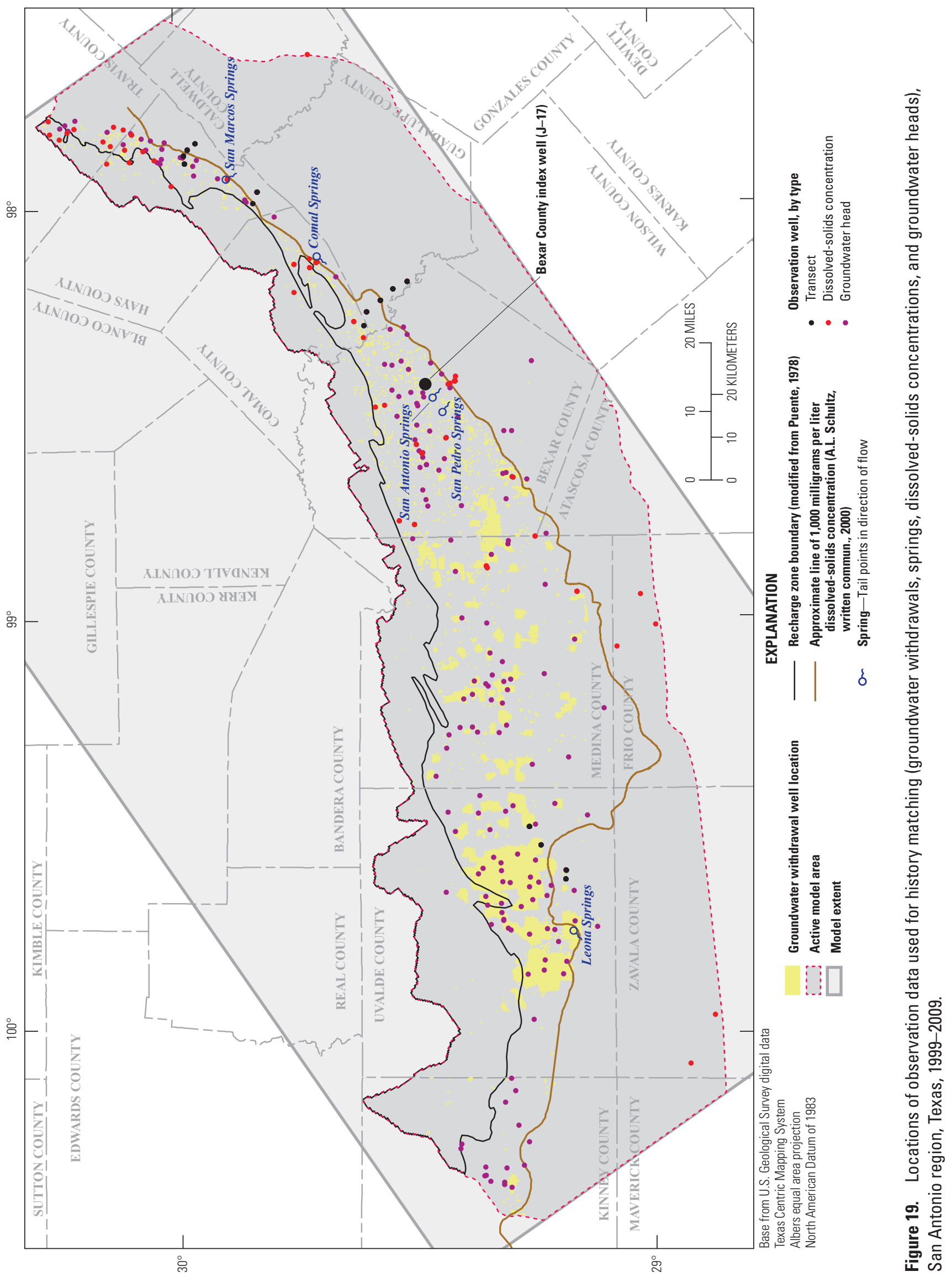




\section{A. Groundwater head (4,232 observations)}
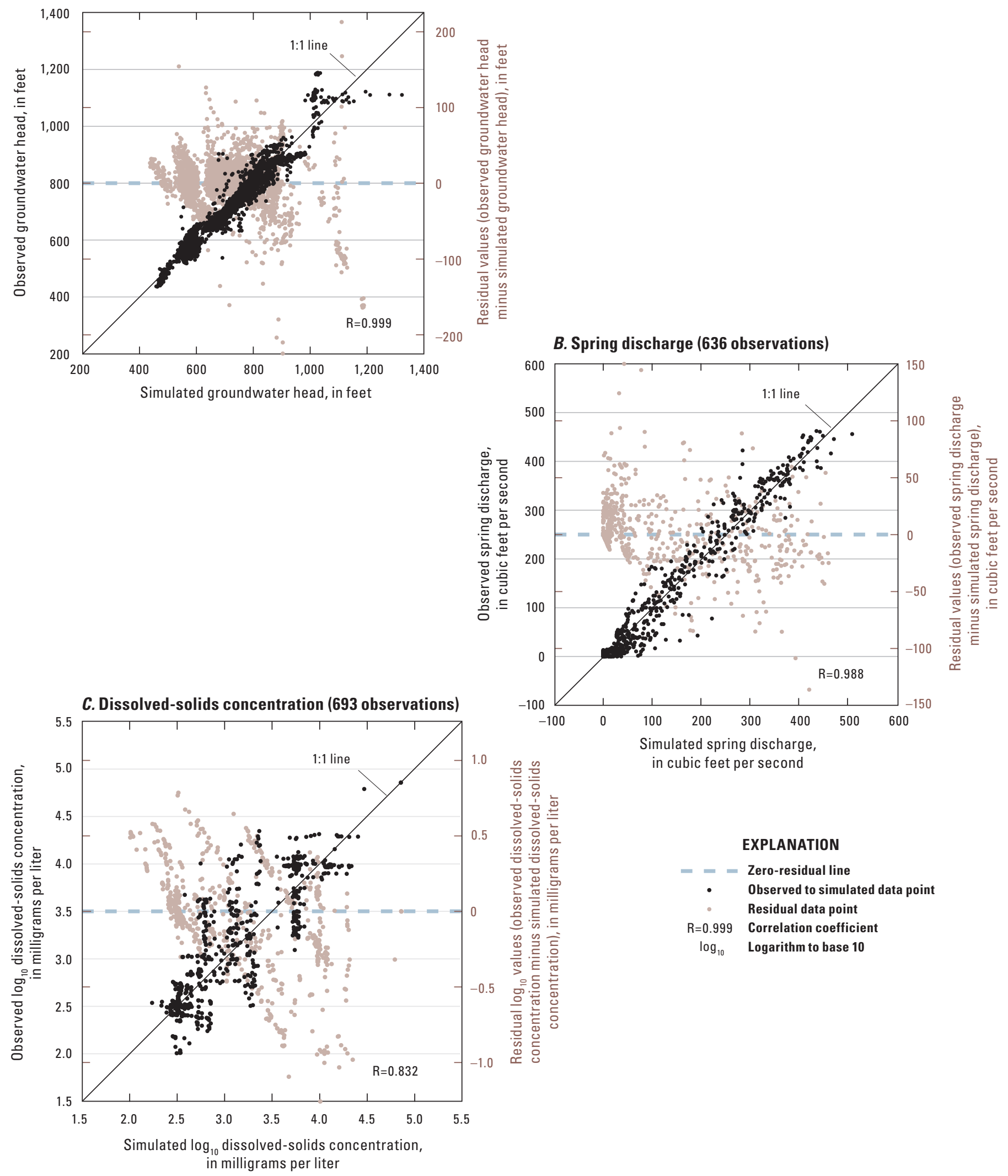

\section{B. Spring discharge (636 observations)}

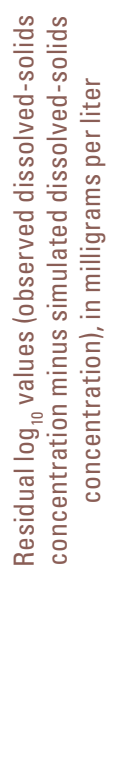

EXPLANATION

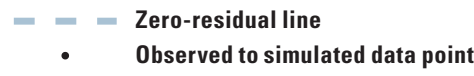

- Residual data point

$\mathrm{R}=0.999$ Correlation coefficient

$\log _{10} \quad$ Logarithm to base 10

Figure 20. Observed values compared to simulated values and residuals for $A$, groundwater heads, $B$, spring discharges, and C, dissolved-solids concentrations, San Antonio region, Texas. 


\section{Goodness of Fit}

In general, the best-fit parameters yield an acceptable fit with the observation dataset for the history-matched model (1999-2009). As an indication of goodness of fit, scatter plots of observed values compared to model-simulated equivalents were prepared with equal-value (1:1) lines, also known as line-of-equality plots. These scatterplots (fig. 20) indicate a good agreement between observations and model-simulated equivalents, and the associated residuals indicate little or no bias over the range of model-simulated values. The correlation coefficient [equation 5.3.2 in Doherty (2015)] was calculated for each scatterplot and is shown on each plot (fig. 20). The calculated correlation coefficients were $0.999,0.988$, and 0.832 for groundwater heads, spring discharges, and dissolved-solids concentrations, respectively. The fit is generally accepted to be better the closer the correlation coefficient is to 1.0. Additionally, comparison of observed and model-simulated time series for key prediction locations (Comal Springs, San Marcos Springs, and well J-17) indicates that the model is generally capable of reproducing important model outputs over the range of hydrologic conditions observed during the model simulation period (fig. 21).

The final, best-fit parameter values are within the acceptable (prior) 95-percent credible interval and, where applicable, are in general agreement with aquifer-specific expert knowledge of the Edwards aquifer system and results of previous history-matched models (Lindgren and others, 2004; Lindgren, 2006). The best-fit spatial distributions of horizontal hydraulic conductivity (fig. 12), in general, agree with the geostatistically derived horizontal hydraulic conductivity spatial distribution of Painter and others (2002), which was used in the model of Lindgren and others (2004, fig. 8) and with the spatial distribution of history-matched hydraulic conductivity of Lindgren (2006, fig. 4). In general, regions of relatively high and low hydraulic conductivities in this model (fig. 12) correspond to relatively high and low hydraulic-conductivity regions in the previous models (except for the high hydraulic conductivity area in the recharge zone at the border between Bexar and Comal Counties). This was also the case for the best-fit specific storage results (fig. 13) when compared to the history-matched storage zone results of previous models (fig. 24 of Lindgren and others, 2004). Previous models focused on the best-fit spatial distributions of these hydraulic parameters because these were the only model inputs used to understand the water budget or regional flow; whereas in this model, the best-fit spatial property distributions of these parameters were supplemented with linear uncertainty analysis, which quantified both parameter and predictive uncertainty.

Whereas traditional measures used to evaluate calibration results indicate the model is acceptably history matched, many of the uncertain parameters that were explicitly recognized during the history-matching process are likely to remain uncertain even after history matching. Unfortunately, if the predictions of interest are sensitive to these uncertain parameters, then considerable prediction uncertainty may also remain following history matching.

\section{Parameter Uncertainty-Schur's Complement for Linear-Based Conditional Uncertainty Propagation}

The prior - the known or expected stochastic character of adjustable parameters determined from expert knowledge, literature values, field tests, previous models, and other sources of information - is depicted in figure 22 as the dashed (log-transformed) Gaussian distributions. In addition to the best-fit parameter values derived from history matching (figs. $12-18$, table 1 ), the posterior (after history-matching) uncertainty of model parameters was also estimated using linear uncertainty analysis. Linear uncertainty analysis is predicated on the linearity assumption between model parameters and observations, which also implies an assumption of Gaussian distributions of parameters, which means the primary quantitative metric for uncertainty in a linear framework is variance (Doherty and others 2010b). Specifically, Schur's complement (Meyer, 2000) for conditional uncertainty propagation (White and others, 2015) is:

$$
\bar{\Sigma}_{\theta}=\sum_{\theta}-\sum_{\theta} J^{T}\left(J \sum_{\theta} J^{T}+\sum_{\varepsilon}\right)^{-1} J \sum_{\theta}
$$

where

$$
\begin{array}{cl}
\sum_{\theta} & \text { is the prior parameter covariance matrix, } \\
J & \text { is the Jacobian matrix, and } \\
\sum_{\varepsilon} & \text { is the covariance matrix of measurement } \\
& \text { noise. }
\end{array}
$$

The matrix $\bar{\Sigma}_{\theta}$ of equation 4 is the posterior parameter covariance matrix, which can be seen as the prior parameter covariance matrix minus the conditioning provided by the observations; conditioning is embodied in the linear mapping provided by the Jacobian matrix. As such, use of equation 4 assumes a linear relation between adjustable parameters and model-simulated observation equivalents and that parameter and measurement noise uncertainty can be described by a multivariate Gaussian (or log-Gaussian) distribution. Fienen and others (2010) discusses a complete derivation of equation 4 from Bayes' equation. The diagonal elements of of equation 4 contain the post-history matching (posterior) parameter uncertainty, expressed as variances (squares of standard deviations) (fig. 22, shaded distributions).

Comparison of the prior (before history matching) and posterior (after history matching) parameter uncertainty plots (fig. 22) (that is, the variances associated with different model parameters) depicts how the information within the observation dataset used for history matching informs many parameters. The information transfer from the observation dataset to the parameters is seen in two ways: (1) through a reduction in posterior variances (reduction of width and increase in height of distribution), and (2) through shifts of the posterior distribution along the $\mathrm{x}$-axis when compared to the prior distribution. 

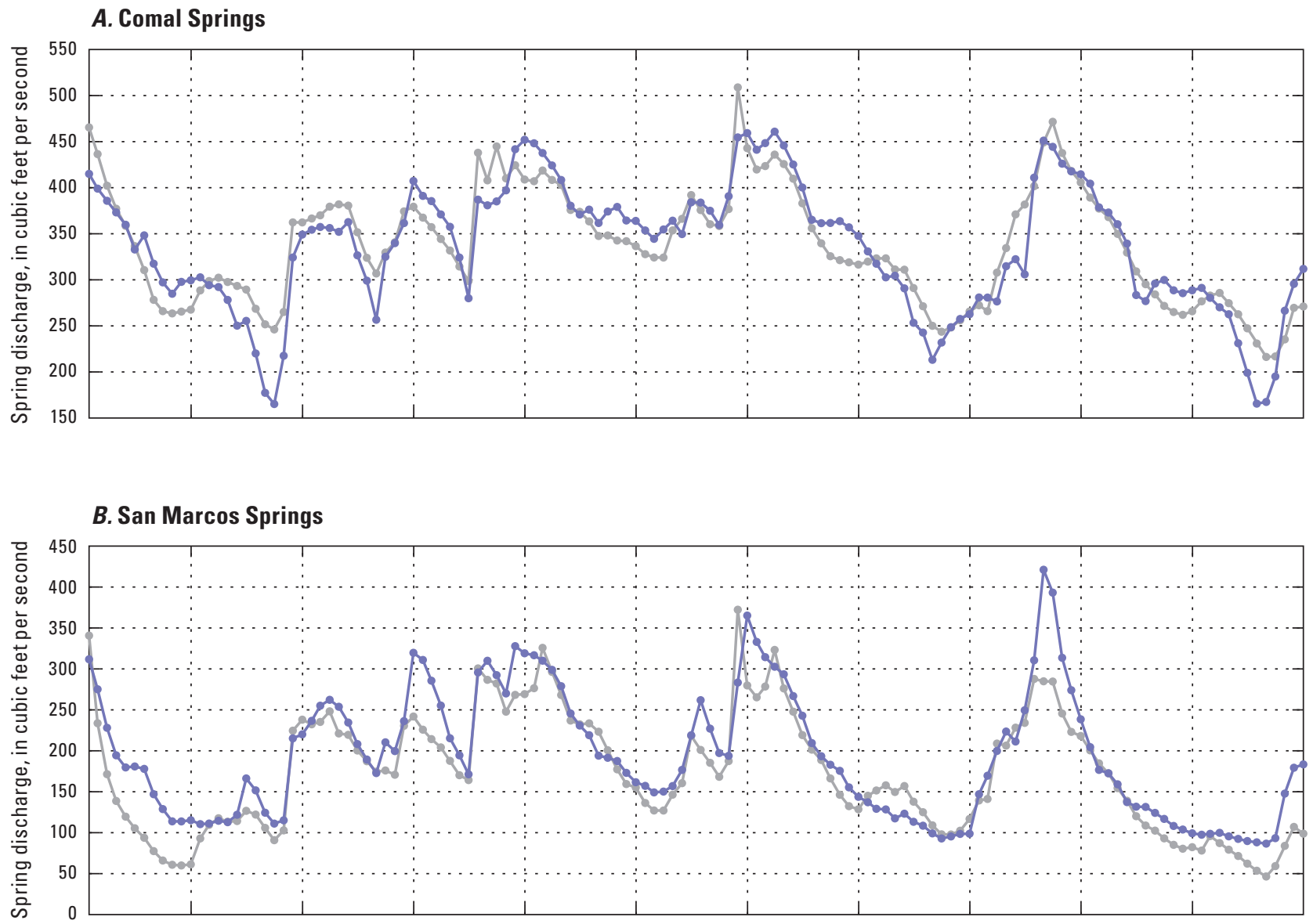

C. Bexar County index well (J-17)

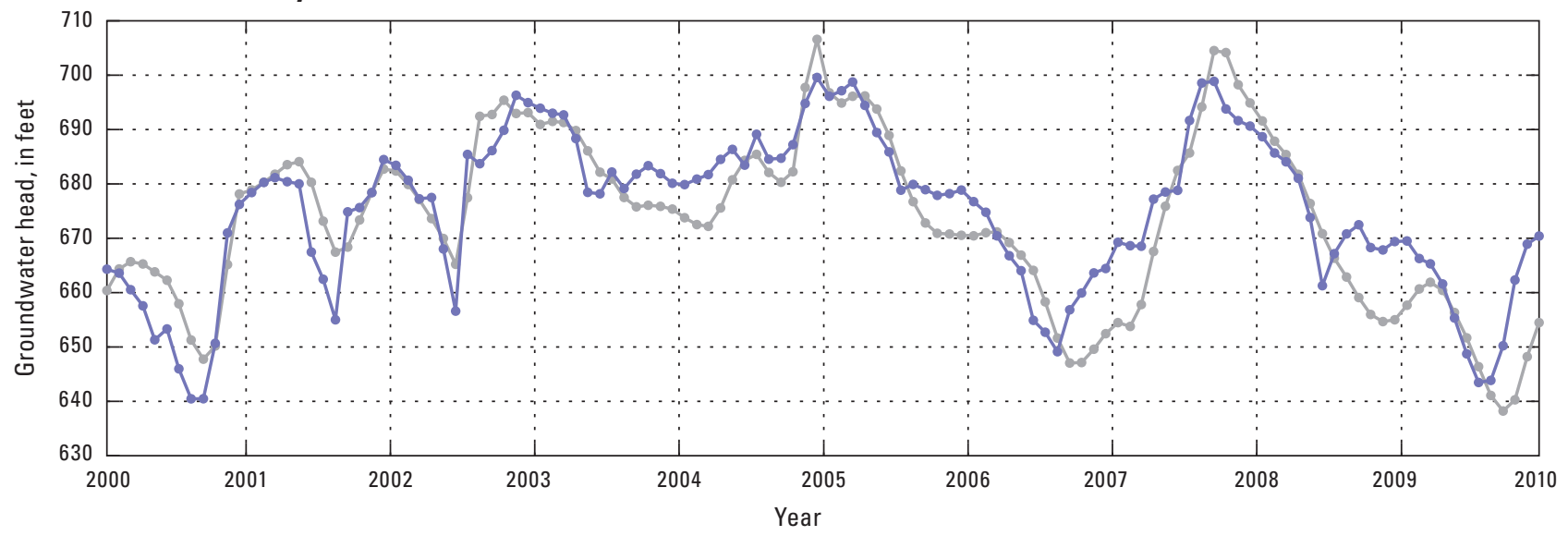

EXPLANATION

$\longrightarrow$ Simulated

Figure 21. Simulated and observed time-series of $A$, Comal Springs discharge, $B$, San Marcos Springs discharge, and $C$, Bexar County index well J-17 groundwater head, San Antonio region, Texas. 


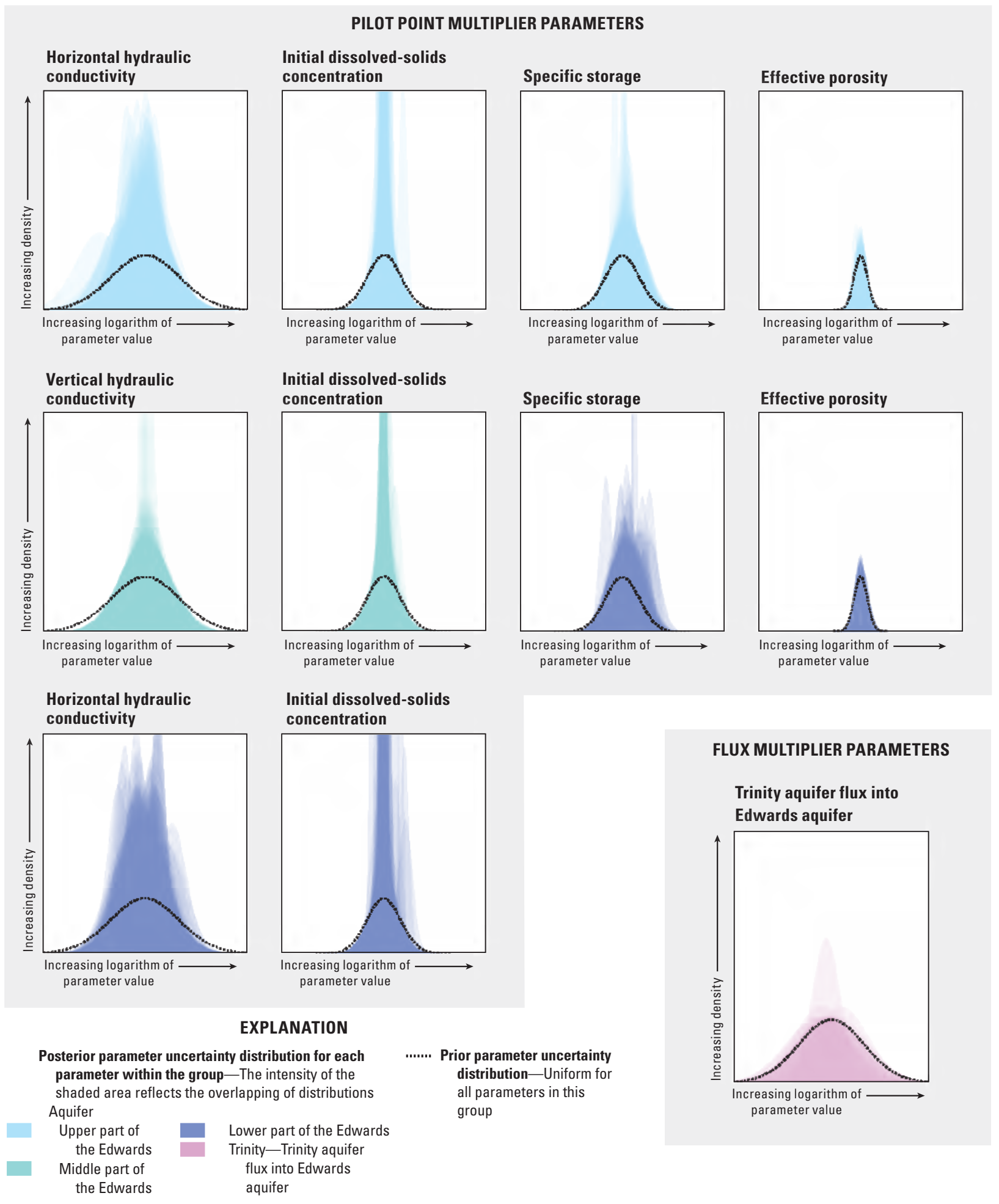

Figure 22. Distributions of prior (before history matching) and posterior (after history matching) parameter uncertainty. 


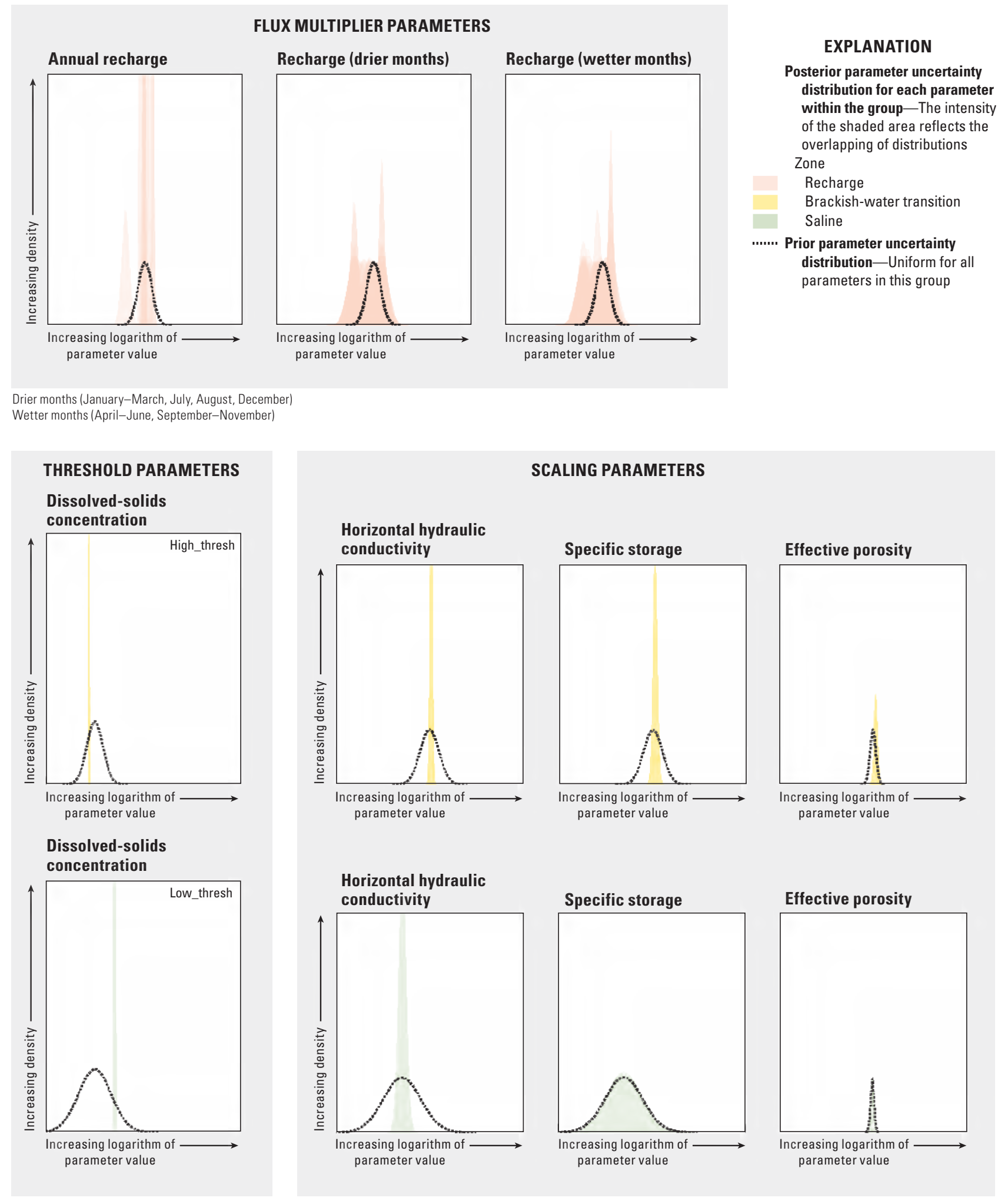

Figure 22. Distributions of prior (before history matching) and posterior (after history matching) parameter uncertainty.-Continued 
The initial (prior) distributions are the same for all individual parameters within a parameter type (for example, the distribution of hydraulic conductivity multiplier pilot point values was the same before history matching). The shaded distributions represent individual posterior (after history matching) distributions of all parameters within each parameter type (for example, the individual drier-month recharge multipliers for each surface-water basin). Therefore, the effects of history matching on individual parameters are depicted in figure 22 through comparison of the prior distribution and the posterior distributions for each parameter type. Where the prior and posterior variances of a given parameter are similar, it can be inferred that the observation dataset contributed little to inform that particular parameter. For example in figure 22, the effective porosity multiplier parameters for the upper and lower parts of the Edwards aquifer have posterior distributions similar to the prior, which indicates that the observation dataset contributed little to inform these parameters and did not decrease their uncertainties through history matching. The dissolved-solids concentration threshold parameters were well-informed by the observation dataset as their posterior distributions were much narrower (lower variance) than their prior distributions. Scaling parameters of hydraulic conductivity, effective porosity, and specific storage for the transition zone (fig. 22) were all informed by the observation dataset, as evidenced by the difference between the prior and posterior variances. Salinezone scaling parameters, on the other hand, were not informed by the observation dataset for effective porosity and specific storage. This is not surprising considering that few observation data have been collected that might inform the porosity or storage of the saline zone. However, uncertainty in the hydraulic conductivity scaling factor for the saline zone was reduced. Note that all of the parameter values shown in these distributions are log-transformed and that most parameters are multiplier values (or scaling parameters) and not necessarily the final values used as inputs to the model. For example, data values for hydraulic conductivity of the distribution for the upper part of the Edwards aquifer are multiplier pilot point values before scaling and kriging to the grid. The high_thresh and low_thresh concentration scaling threshold parameters are not multiplier values but are the actual history-matched threshold values (log-transformed) (in pounds per cubic feet instead of $\mathrm{mg} / \mathrm{L}$ ).

Resulting posterior drier-month, wetter-month, and annual recharge multiplier parameter variances are important to understanding how reliably recharge is estimated and implemented in the model. The shifts of the posterior distributions to the left and right of the prior distribution indicate that some zones in the model needed less or more simulated recharge as a model input in order to achieve an acceptable history-matching result (fig. 22). Many of the best-fit recharge parameters (fig. 22) are not statistically different from the initial values specified in the history-matching effort; the widths of the distributions of the different recharge parameters did not decrease substantially as a result of history matching. Recharge from rainfall is the driving force behind groundwater flow and heads in the aquifer; therefore, an increased understanding of the complex Edwards aquifer recharge process would benefit model development by potentially decreasing the uncertainty of this parameter.

The history-matching effort was helpful in informing the parameters that control spring discharge, namely, the DRN altitude and conductance parameters for each spring. These distributions were not shown in figure 22 because the distributions were narrow, indicating these parameters were strongly informed by the observation dataset.

\section{Uncertainty Assessment of 1950-56 Drought Conditions on Brackish-Water Movement within the Edwards Aquifer}

The best-fit parameters inferred through the historymatching effort are not likely to be "correct" parameters, but instead represent minimum error variance parameters. Therefore, in the predictive phase, results of hypothetical scenarios from the predictive model based on the best-fit parameters should be evaluated with explicit consideration of parameter uncertainty. Traditional groundwater modeling analyses would use the best-fit parameters to yield one estimate of the model predictions through a single forward run of the predictive model. However, any remaining posterior uncertainty in prediction-sensitive parameters means that many parameter sets can reproduce the observation dataset as well as the best-fit parameter set, but each of these parameter sets may yield different values of the model predictions. Therefore, it is imperative that posterior parameter uncertainty be propagated to the model predictions to evaluate uncertainty in the model predictions because rigorous assessment of prediction uncertainty provides important insights into the reliability of model predictions, compared to using only the single, best-fit parameters.

Uncertainty analysis was completed using equation 4 combined with predictive sensitivity vectors (vectors that contain the sensitivity of the prediction with respect to all adjustable parameters) to quantify predictive uncertainty. To propagate parameter uncertainty to predictions of interest, the following relations (White and others, 2015; Doherty and others, 2010b) were used:

$$
\sigma_{s}^{2}=y^{T} \sum_{\theta} y ; \bar{\sigma}_{s}^{2}=y^{T} \bar{\Sigma}_{\theta} y
$$

where

$y \quad$ is the sensitivity vector of prediction $s$ with respect to the adjustable parameters, and $\sigma_{s}^{2}$ and $\bar{\sigma}_{s}^{2}$ are the prior and posterior variances of prediction $s$, respectively and all other terms are previously defined in equation 4 . 
Although regional changes in the position of the transition zone during the predictive period are of ultimate interest, the three key quantitative targets for this predictive model and uncertainty analysis were (1) changes in dissolved-solids concentrations at 25 production wells near the transition-zone interface, (2) discharge at Comal and San Marcos Springs, and (3) the head at well J-17. These three quantitative targets are helpful for evaluating the effect of sustained drought on the San Antonio segment of the Edwards aquifer.

\section{Predictive Phase}

In the predictive phase, the model extent, boundary locations and types, aquifer geometry, grid layering, and discretization of the predictive model are the same as in the historymatched model (1999-2009). The only two aquifer stresses that were changed for the predictive model were recharge and groundwater withdrawals at production wells. The Trinity aquifer flux through the northern boundary of model layer 8 (fig. 5) was the same as that of the history-matched model. Drains used to simulate major springs with the DRN were used with altitude and conductance values from the historymatched model as well. Spatial property distributions of hydraulic conductivity, effective porosity, and specific storage were also from the history-matched model. Monthly stress periods were used for the 7 years of drought (1950-56) and initial conditions for heads and dissolved-solids concentrations were obtained from the initial heads and dissolved-solids concentrations of the history-matched model. These initial conditions were used because this predictive model is not a hindcast of 1950s groundwater conditions in the Edwards aquifer, but is a hypothetical forecast prediction of effects of the combination of modern withdrawal rates and drought-of-record rainfall conditions on the three predictive targets.

\section{Drought Recharge Conditions 1950-56}

The history-matched model period of 1999-2009 does not best represent drought-of-record conditions in southcentral Texas. The current (2015) driest year on record was 2011 (Winters, 2013). The drought of the 1950s has been used as an important simulation event or target with other models of the Edwards aquifer and other groundwater models in Texas (Lindgren and others, 2004; Winters, 2013). However, this period is especially important for the Edwards aquifer because the only period of zero flow from Comal Springs was recorded from June 13, 1956, to November 4, 1956 (Maclay, 1995). Monthly recharge estimates of the 1950s have previously been used for the Edwards aquifer models (Lindgren and others 2004; Lindgren 2006; Slattery, 2004). These recharge estimates were used in the $\mathrm{RCH}$ of this predictive model using the same zonation scheme as the 1999-2009 historymatched model. The drier-month, wetter-month, and annual recharge multiplier parameters were also implemented in this predictive model to determine effects of uncertainty in these multipliers from the history-matched model on uncertainty in the predictions.

\section{Withdrawals by Wells}

Groundwater withdrawals for the predictive model were implemented using the WEL using the same well locations as those implemented in the history-matched model. However, the individual monthly withdrawal rate for each well was specified to be the 85th percentile of all withdrawal rates for a given month, which produced 12 withdrawal rates for each well. This same one-year long, monthly withdrawal time series for each well was used for each year of the 1950-56 period. Therefore, the predictive model represents a hypothetical scenario of the drought of the 1950s combined with hypothetical increased groundwater withdrawal rates.

The focus of the predictive model was to evaluate changes in hydrologic conditions in a regional perspective across the San Antonio segment of the Edwards aquifer, but production wells near the transition-zone interface (fig. 10) were specifically targeted to estimate the change in dissolvedsolids concentration in water withdrawn from the wells from the beginning to the end of the model simulation. Concentration changes at these wells were used as model predictions because regional maps could not show the movement of the transition zone at a meaningful scale. These 25 wells were selected because they are near the transition-zone interface (fig. 10) and nonpotable water could be withdrawn during drought conditions.

Groundwater fluxes and cumulative volumes simulated by the predictive model (fig. 23), based on best-fit historymatched parameter distributions, indicate that drought conditions (1950-56) eventually lead to a depletion of spring discharge as groundwater heads decrease until the withdrawals by wells are eventually balanced by depletion in storage (fig. 23). Compared to the history-matched water budget, predictive cumulative volumes of simulated recharge and spring discharge are much smaller, depletion of storage is much larger, and withdrawals by wells are similar.

\section{Prediction Uncertainty-Schur's Complement for Linear-Based Conditional Uncertainty Propagation}

Linear uncertainty analysis was completed in this assessment and is discussed in great detail in Doherty and others (2010b, appendix 4). Linear uncertainty analysis is based on the assumption that model-simulated equivalents (model outputs) are linearly related to parameters (model inputs) through the single Jacobian sensitivity matrix, which contains the sensitivities of each model-simulated equivalent to each model parameter. A second, implied assumption is that the parameter variability and interaction is characterized by a multivariate Gaussian distribution (or the log of the parameter variability 

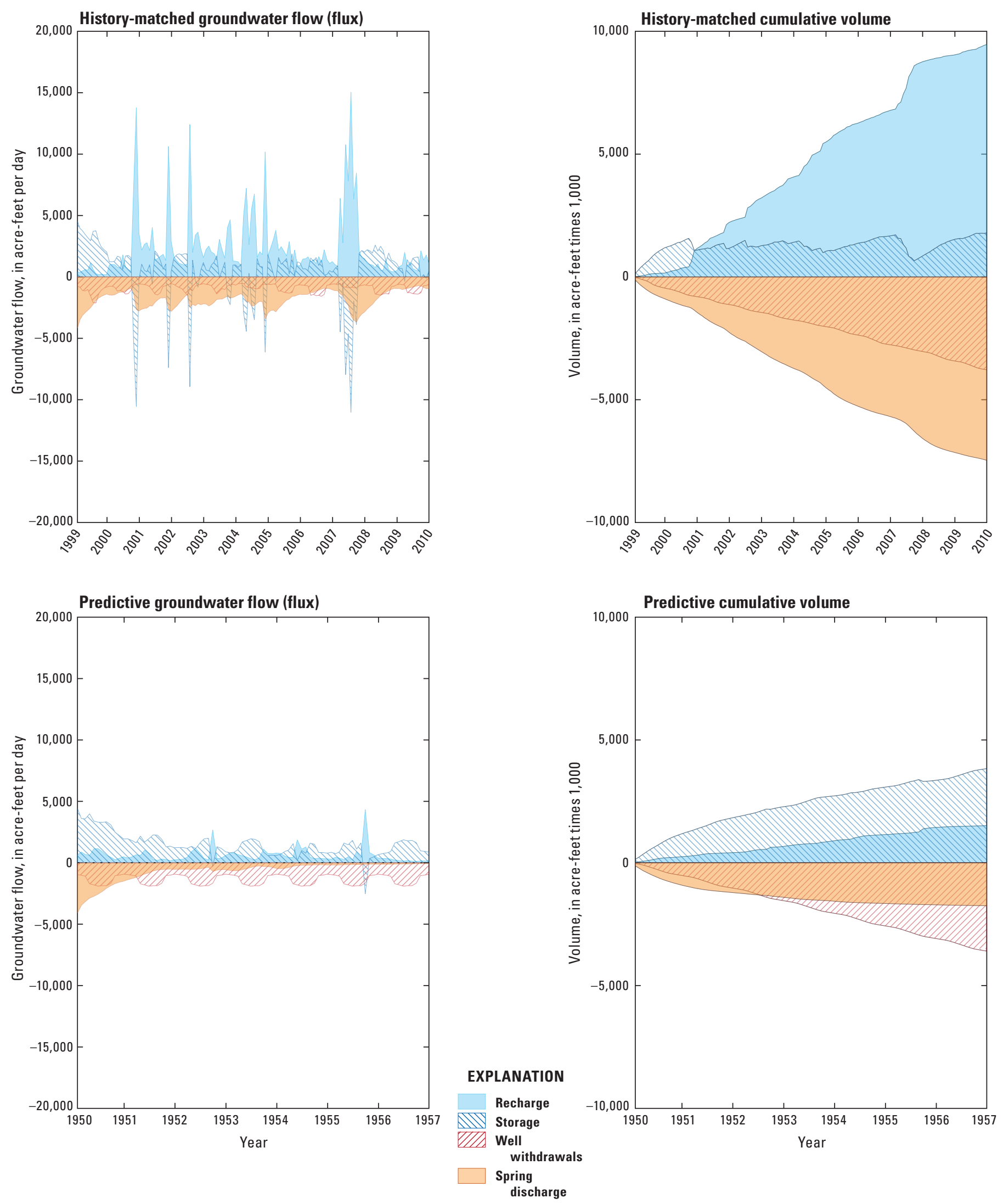

Figure 23. Groundwater flows (fluxes) and cumulative volumes for the history-matched model (1999-2009) and the predictive model (1950-56), San Antonio region, Texas. Positive values represent groundwater gains, and negative values represent groundwater losses. 
is Gaussian). The goal of predictive linear uncertainty analysis is to quantify predictive uncertainty of the model based on parameter uncertainty using information gained from the observation dataset through the history-matching effort. This uncertainty analysis is done under the hypothesis that the history-matching effort reduces the uncertainty of the model predictions from the prior uncertainty by transferring information from the observation dataset to prediction-sensitive parameters.

The prior parameter uncertainty for the predictive analysis was inherited from the parameter uncertainty analysis. These prior uncertainty estimates were based on expert knowledge of a range of the potential values for the parameters before the history-matching effort (refer to the "Parameterization" section). Using equation 5, the prior uncertainty estimates were propagated to several key model predictions, including dissolved-solids concentration changes in water at wells near the transition-zone interface, spring discharges at Comal and San Marcos Springs, and head at well J-17.

To investigate the effects of history-matching information on the prediction, equation 4 was combined with equation 5 to yield posterior prediction uncertainty estimates. The resulting posterior predictive uncertainty was used to estimate the upper and lower bound of the 95-percent credible interval for each model prediction. For the production wells of predictive interest (fig. 10), the upper bound represents a conservative estimate of the expected concentration change under the hypothetical recurrence of drought conditions.

\section{Predictive Uncertainty Results}

Predictive uncertainty analysis results at the 25 production wells near the transition-zone interface indicate that the prior uncertainty of model input parameters (based on expert knowledge) yielded an upper bound of the 95-percent credible interval of dissolved-solids concentrations that exceeds the secondary drinking water standards of 1,000 mg/L (Texas Commission on Environmental Quality, 2013) for many of the wells (fig. 24). The initial concentration of dissolved solids at these wells was $325 \mathrm{mg} / \mathrm{L}$; therefore, an increase of greater than $675 \mathrm{mg} / \mathrm{L}$ (the y-axis of fig. 24) represents a final concentration greater than $1,000 \mathrm{mg} / \mathrm{L}$. However, the history-matching effort provided key information to inform prediction-sensitive model parameters, and, therefore, contributed to a substantial decrease of the upper bound of the posterior 95-percent credible interval (when compared to the prior) to below the secondary drinking water dissolved-solids concentration standards (fig. 24). Reductions in dissolvedsolids concentration change were on the order of $400 \mathrm{mg} / \mathrm{L}$ (at wells $5,12,16$, and 25) to $1,300 \mathrm{mg} / \mathrm{L}$ (at wells $2,8,9,11$, and 13). The reduction in uncertainty in regards to this prediction

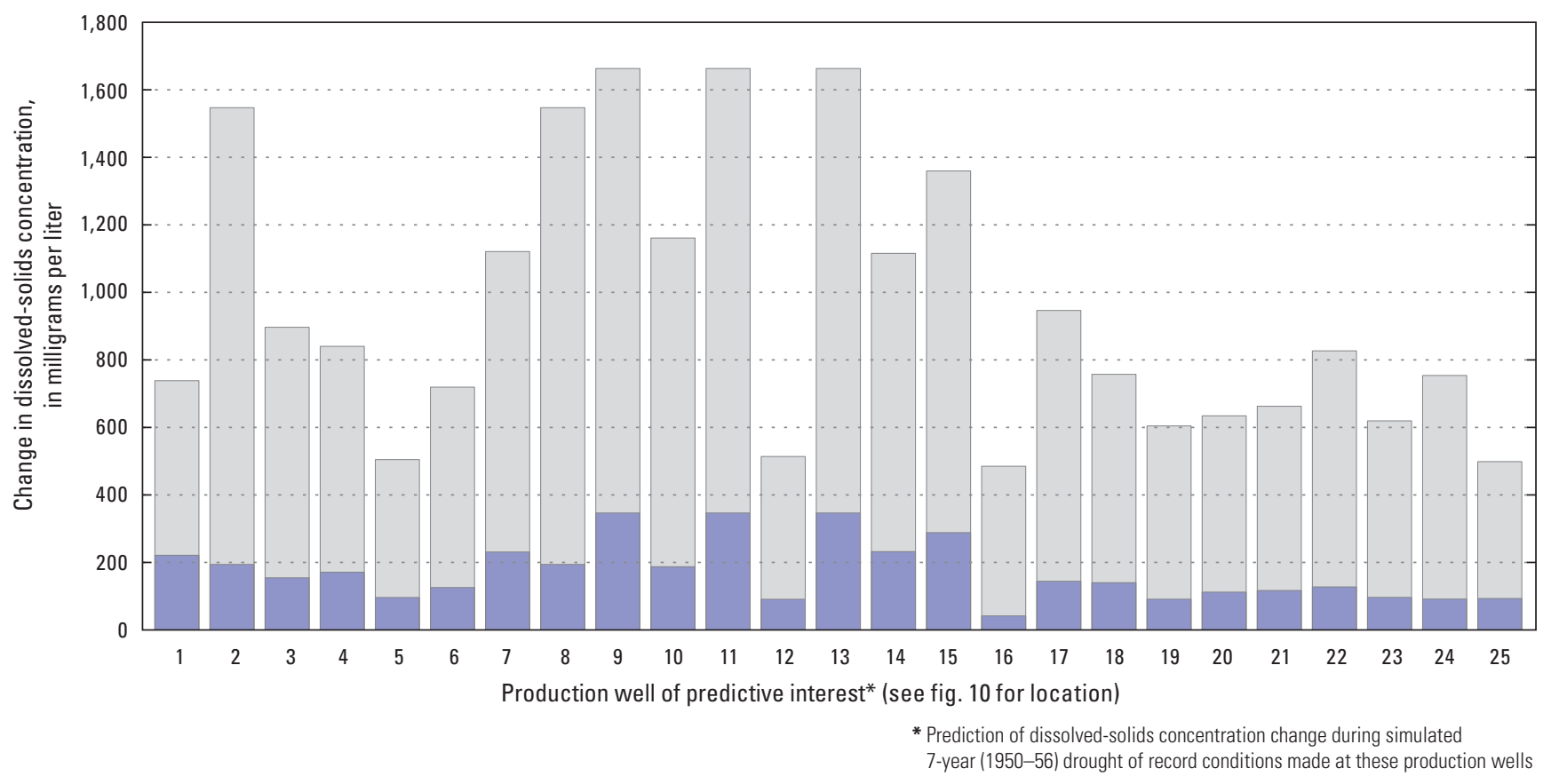

\section{EXPLANATION}

Upper bound of 95-percent credible interval- Change during the 1950-56 predictive model period

Prior (before history-matching) uncertainty of prediction

Posterior (after history-matching) uncertainty of prediction

Figure 24. The upper bound of the 95-percent credible interval for the prior and posterior predictive uncertainty of dissolved-solids concentration change during the 1950-56 predictive model period at production wells of interest. 
implies that this prediction can be made with some certainty and that those parameters that control this prediction are informed by the observation dataset. Even though predictive uncertainty was reduced for this prediction, dissolved-solids concentration changes were still greater than zero, indicating a minimal increase in concentration is likely at these 25 production wells during the 7-year simulation period. This minimal concentration increase indicates a small potential for movement of the transition zone near these wells during the hypothetical recurrence of 1950-56 drought-of-record rainfall conditions with higher-than-average groundwater withdrawals by wells.

Predictive results of total spring discharge during the seven-year period, as well as the prediction of head at well $\mathrm{J}-17$, were much less reliable than the prediction of changes in dissolved-solids concentrations at the production wells. The predicted total spring discharges for Comal and San Marcos Springs were about 401,000 and 165,930 acre-feet (acre-ft), respectively. The predicted head at the end of the predictive model period for well J-17 was $460 \mathrm{ft}$ above NGVD 29. More important than the predicted values are the widths of the 95-percent credible intervals of these predictions. For example, the upper bound of the 95-percent credible interval of total discharge at Comal and San Marcos Springs at the end of the model simulation are about 6,080,600 and 1,244,750 acre$\mathrm{ft}$, respectively. The upper bound of the 95-percent credible interval of head at well J-17 at the end of the model simulation is $3,280 \mathrm{ft}$. These upper bounds are an order of magnitude larger than the actual predictions, which implies that (1) these predictions of spring discharge at Comal and San Marcos Springs and head at well J-17 simulated with this model are not reliable, and (2) parameters that control these predictions are not informed well by the observation dataset during history matching, even though the history-matching effort yielded parameters to reproduce spring discharge and heads at these locations during the history-matching period. This large posterior uncertainty is an example of how history matching is successful in yielding best-fit parameters, which allows for sufficient simulation of heads and spring discharge (see fig. 21), but is unsuccessful at reducing the uncertainty of parameters that control predictions made at these same locations. In other words, history matching is sufficient to yield best-fit parameter estimates but not necessarily sufficient to produce reliable predictions. Furthermore, spring discharges at these two springs and head at well J-17 represent a cumulative effect of upstream conditions over a larger extent within the Edwards aquifer (and a longer time). Therefore, many more parameters (with their own uncertainties) are potentially controlling the spring discharge and head predictions than the prediction of dissolved-solids concentration change at the prediction wells, and, therefore contributing to a large posterior uncertainty. Spring discharges and heads in the Edwards aquifer respond much more quickly and fluctuate with a greater magnitude than the dissolved-solids concentrations. The apparent lack of transition zone movement is the result of the stable density configuration of the Edwards aquifer transition zone and saline zone. That is, the brackish-water transition and saline zones inherently resist moving, with most groundwater flowing parallel to the transition-zone interface rather than normal to the interface. It should be noted that the predictions of spring discharge and head were absolute predictions, which are more difficult to accurately make than the difference prediction of dissolved-solids concentration change (difference from the beginning of the model simulation to the end of the model simulation) at the production wells.

\section{Model Limitations}

Models are inherently flawed and therefore, have limitations as they are simplified simulators of a much more complex natural system (Box and Draper, 1987). Model limitations need to be discussed and model results need to be understood in the context within which the model was designed and developed. Furthermore, any interpretations of model results should be in accordance with the assumptions made in developing that model, which must also coincide with the prediction of interest.

Model error is a term that is used to describe the discrepancy between the model and the more complex, natural system it simulates (White and others, 2014). Sources of model error might include horizontal and vertical discretization error, parameter lumping and vertical averaging of properties, and the assumption of an equivalent porous media. Errors in simulated heads were expected in the recharge zone of the model because a confined approximation was used to simulate all layers of the model. The recharge zone is unconfined; using a confined approximation reduced numerical convergence issues in the model, decreased model run times, and most importantly, the focus of the modeling effort was on transition-zone movement within the confined part of the aquifer, not the recharge zone. Recharge from rainfall is the driving force behind groundwater flow and heads in the aquifer; therefore, an increased understanding of this process would benefit model development by potentially decreasing the uncertainty of this parameter. Decreasing the uncertainty of recharge parameters might be accomplished through a more rigorous simulation of the rainfall-to-recharge landscape partitioning process with a hydrologic model. Some information on groundwater withdrawals was only available in aggregated spatial and temporal scales, which may cause localized spatial and temporal error in simulated heads near these wells. Where well-construction information was not available, groundwater withdrawals were simulated from the entire thickness of the Edwards aquifer. In other cases, the screened interval was used to determine the layers in which groundwater withdrawal was simulated. Only major springs were simulated in the model, but many smaller springs are known to exist where Edwards aquifer water is potentially discharging. Localscale dissolution features and faulting at springs may not be fully represented because of the scale of the model and grid 
discretization, and these features may be better simulated in a local-scale, finely discretized model. Given the highly karstified character of the Edwards aquifer, the assumption of an equivalent porous media is likely to be violated at smaller spatial scales. Therefore, using the model to understand localscale groundwater flow and transport processes may not be appropriate.

Few data from the transition zone and saline zone are available to characterize geologic structure, faults, aquifer properties, and distributions of heads and dissolved-solids concentrations. Some of these information deficits could be reduced through more stratigraphic determinations of Edwards aquifer tops and bottoms from existing geophysical logs and conversions of geophysical logs to dissolved-solids estimates. The assumption of the southern boundary as a no-flow, constant-concentration boundary condition is sufficient for the predictions made herein with this model, but small amounts of water might flow across this boundary changing the concentration of dissolved solids at this boundary over time.

This modeling analysis assumes simulated dissolvedsolids concentrations are only related to transition-zone and saline-zone processes. Furthermore, more complicated geochemical processes and reactions were not simulated within this model. In essence, water-density is dependent upon dissolved-solids concentration, which is simulated as a conservative constituent in the model.

Water density is also dependent upon temperature and regions of elevated temperature are known to occur within the subsurface at depths in the Edwards, resulting from geothermal heat flux (Groschen and Buszka, 1997). Furthermore, viscosity of groundwater can also be affected by temperature changes and dissolved-solids concentration changes (Langevin and others, 2008), but heat-transport and variable-viscosity effects were not simulated in this analysis. The effects of temperature increases on density and the effects of temperature increases and dissolved-solids concentration on viscosity were assumed to be negligible in the transition-zone water.

Perhaps the largest limitation of the current model is the relative short period simulated for the history-matched model. Parameter knowledge gained from the observation dataset (as visualized in changes in the posterior parameter uncertainty when compared to the prior) only represents conditions from 1999 through 2009 because this is the period for which higher-resolution model input datasets were available to support a complex, transient, variable-density modeling analysis. Construction and history matching of a full period-of-record model would encompass more historical observations (longer record for heads, major spring discharges, and dissolvedsolids concentrations) of the Edwards aquifer, but would require additional assumptions about the spatial and temporal distribution of groundwater withdrawal rates. However, the increased size of the observation dataset for a full period-ofrecord model has the potential to further reduce uncertainty of parameters - most importantly - potentially those parameters that control the predictions of spring discharge and head at well J-17.
Uncertainty analysis presented herein, while comprehensive in the inclusion of uncertain model parameters and processes, is predicated on a linearity and normality assumption, which carries with it its own assumptions of multivariate Gaussian distributions of parameters and predictions as well as an assumed linear relation between observations and parameters which may not be completely accurate (Doherty and others, 2010b). Whereas it has been demonstrated that linear analysis in the context of variable-density modeling is capable of providing robust uncertainty estimates (Dausman and others, 2010b), more advanced uncertainty quantification techniques, such as null-space Monte Carlo (Doherty and others, 2010b), may provide additional information and understanding of parameter and predictive uncertainty.

The predictive model in this assessment was based on a hypothetical recurrence of drought-of-record (1950-56) rainfall and higher-than-average groundwater withdrawals by wells. The predictions of interest are specific to these rainfall and withdrawal conditions at the 25 production wells, Comal and San Marcos Springs, and well J-17 where predictions were made. Results of the predictions of interest should not be extrapolated to other locations within the Edwards aquifer or to other hydrologic conditions.

\section{Summary}

In 2010, the U.S. Geological Survey, in cooperation with the San Antonio Water System, began a study to assess the brackish-water movement within the Edwards aquifer (more specifically the potential for brackish-water encroachment into wells near the interface between the freshwater and brackish-water transition zones, referred to in this report as the transition-zone interface) and effects on spring discharge at Comal and San Marcos Springs under drought conditions using a numerical model. The quantitative targets of this study are to predict the effects of higher-than-average groundwater withdrawals and drought-of-record (1950-56) rainfall conditions on (1) dissolved-solids concentration changes at production wells near the transition-zone interface, (2) total spring discharge at Comal and San Marcos Springs and (3) the head at Bexar County index well J-17 (hereinafter referred to as "well J-17"). The predictions of interest, and the parameters implemented into the model, were evaluated to quantify their uncertainty so results of predictions could be presented in terms of a 95 -percent credible interval.

The model area covers both the San Antonio and Barton Springs segments of the Edwards aquifer although the historymatching effort was focused on the San Antonio segment. The diffuse-flow model, which forms the basis for the model in this assessment, is primarily based on a conceptualization in which flow in the aquifer is predominately through a network of numerous small fractures and openings. In this assessment, the major changes from the diffuse-flow model that were 
incorporated into the history-matched model (1999-2009) are summarized:

1. More active model cells were used to simulate the brackish-water transition zone and saline zone downdip of the freshwater zone.

2. The one-layer model was converted to an 8-layer model to better represent vertical aquifer heterogeneity and anisotropy as well as simulate variable-density flow and transport. Discussion of the model is in terms of the "upper" (layers 1-3), "middle" (layer 4), and "lower" (layers 5-8) parts of the Edwards aquifer based on the hydrostratigraphy.

3. SEAWAT version 4 was used to explicitly simulate variable-density flow and transport.

4. The history-matching period was updated to 1999-2009.

5. Parameter estimation, through history matching, was executed using highly parameterized inversion with PEST to calibrate to heads, discharges at major springs, and dissolved-solids concentrations at wells.

The parameterization of the numerical model used a combination of pilot points and piece-wise zones of uniform aquifer property values. The final parameterization was based on many iterations of parameterization and history matching, which required use of dissolved-solids concentration threshold and scaling parameters to best represent the different hydraulic properties associated with different water-quality zones of the Edwards aquifer. To represent the relations between water chemistry and karst flow-system properties in the historymatching effort, two threshold parameters were estimated, with each threshold parameter having three associated scaling parameters, one for hydraulic conductivity, one for specific storage, and one for effective porosity. The cumulative effect of this parameterization process is a flexible and automated hydraulic property adjustment procedure that approximates karstic alteration that has occurred within the Edwards aquifer along the brackish-water transition zone between freshwater and saline water. The best-fit estimates of these threshold and scaling parameters are consistent with the hydrogeologic and geochemical understanding of the existence of highly transmissive preferential-flow areas within the vicinity of the "bad-water line" of $1,000 \mathrm{mg} / \mathrm{L}$ dissolved-solids concentration (which falls within the range of high_thresh to low_thresh estimates of 329 to $2,074 \mathrm{mg} / \mathrm{L}$ ).

In general, the best-fit parameters yield an acceptable fit with the observation dataset. Traditional measures of goodness-of-fit, such as the line-of-equality plots and correlation coefficients, indicate good agreement between observations and model-simulated equivalents and little or no bias over the range of observed values. Additionally, comparison of observed and model-simulated time series for several key observation series indicate the model is generally capable of reproducing important model outputs over a range of hydrologic conditions.
In addition to best-fit parameter values derived from history matching, the uncertainty of model parameters was also estimated using linear uncertainty analysis. Comparison of prior (before history matching) and posterior (after history matching) variances of parameters indicates that the information within the observation dataset used for history matching informs many parameters. This is seen in two ways:

(1) through a reduction in posterior variances (reduction of width and increase in height of distribution) or (2) shifts of the posterior distribution along the $\mathrm{x}$-axis when compared to the prior distribution. The effective porosity multiplier parameters have posterior distributions similar to the prior, which indicates that the observation dataset did not inform this parameter well, and therefore did not decrease its uncertainty. The concentration threshold parameters were well-informed by the observation dataset as their posterior distributions were much narrower than their prior distributions. The transition-zone scaling parameters of hydraulic conductivity, effective porosity, and specific storage were all informed by the observation dataset, as evidenced by the difference between the prior and posterior variances. Saline-zone scaling parameters, on the other hand, were not informed by the observation dataset for effective porosity and specific storage. This is not surprising considering the lack of data within the saline zone. The history-matching effort was most helpful in informing the parameters that control spring discharge, namely, the altitude and conductance parameters for each spring. These posterior distributions were not shown because they were so narrow. The reduction in width implies that these parameters were strongly informed by the observation dataset.

Resulting posterior drier-month, wetter-month, and annual recharge multiplier parameter variances are important to understanding how well recharge is estimated and implemented within the model. The shifts of the posterior distributions left and right indicate that there were zones where less or more water was needed in the model. The widths of the distributions were not decreased substantially, indicating that many of the best-fit recharge parameters are not statistically different from the initial values specified in the history-matching effort. Recharge from rainfall is the driving force behind groundwater flow and heads in the aquifer; therefore, an increase in understanding of this process would benefit model development by potentially decreasing the uncertainty of this parameter.

The predictive model in this assessment simulated a hypothetical recurrence of 1950-56 drought conditions and higher-than-average groundwater withdrawals by wells to provide insight into the potential effects of these conditions on dissolved-solids concentration changes at production wells near the transition-zone interface, discharges at Comal and San Marcos Springs, and groundwater head at well J-17. The only two aquifer stresses changed for the predictive model were that of aquifer recharge and groundwater withdrawals by wells. The 85th percentile of all withdrawal rates for a given month for each well was calculated, and a monthly time series was created and implemented into the model well package. This same one-year monthly withdrawal time series for each 
well was used for each year of the 1950-56 predictive model period.

The uncertainty of the predictions made with the predictive model was quantified using linear uncertainty analysis. The goal of predictive linear uncertainty analysis was to quantify predictive uncertainty of the model based on parameter uncertainty using information gained from the observation dataset through the history-matching effort. The expectation is that the history-matching effort reduces the uncertainty of the model predictions from the prior uncertainty by transferring information from the observation dataset to predictionsensitive parameters. The resulting posterior predictive uncertainty was used to estimate the upper and lower bound of the 95-percent credible interval for each model prediction. For the production wells of predictive interest, the upper bound represents a conservative estimate of the expected concentration change under the prediction conditions.

The uncertainty assessment of the predictive model yielded 95-percent credible intervals of dissolved-solids concentration changes at 25 production wells near the transitionzone interface, discharges at Comal and San Marcos Springs, and head at well J-17. Results at the 25 production wells near the transition-zone interface indicate that the uncertainty of model input parameters based on expert knowledge (prior uncertainty) yielded an upper bound of the 95-percent credible interval of dissolved-solids concentrations that exceeds the secondary drinking water standards of $1,000 \mathrm{mg} / \mathrm{L}$ for many of the wells. However, the history-matching effort provided key information to inform prediction-sensitive model parameters, and, therefore, contributed to a substantial decrease of the upper bound of the 95-percent credible interval to below the secondary drinking water standards. Reductions in dissolvedsolids concentration change were on the order of $400 \mathrm{mg} / \mathrm{L}$ to $1,300 \mathrm{mg} / \mathrm{L}$. The reduction in uncertainty in regards to this prediction implies that this prediction can be made with some certainty using this model and that those parameters which control this prediction are informed by the observation dataset. Even though predictive uncertainty was reduced for this prediction, dissolved-solids concentration changes were still greater than zero, indicating a minimal increase in concentration is likely at these 25 production wells during the 7 -year simulation period. This minimal concentration increase indicates a small potential for movement of the brackish-water transition zone near these wells during the 7-year simulation period simulating a hypothetical recurrence of drought-ofrecord (1950-56) rainfall conditions with higher-than-average groundwater withdrawals by wells.

Predictive uncertainty results for total spring discharge at Comal and San Marcos Springs during the 7-year period, as well as the results for head predictions at well J-17, were substantially different than the dissolved-solids concentration change uncertainty results at the production wells. The upper bounds of the 95-percent credible intervals for spring discharge at Comal and San Marcos Springs and heads at well J-17 were an order of magnitude larger than the actual predictions (based on best-fit parameters) which implies that
(1) these predictions made with this model are not reliable and (2) parameters that control these predictions are not informed well by the observation dataset during history matching, even though the history-matching effort yielded parameters to reproduce spring discharges and heads at these locations during the history-matching period. Furthermore, because discharges at Comal and San Marcos Springs and heads at well J-17 represent more of a cumulative effect of upstream conditions over a larger distance (and longer time), many more parameters (with their own uncertainties) are potentially controlling these predictions than the prediction of dissolved-solids concentration change at the prediction wells, and therefore contributing to a large posterior uncertainty.

\section{References Cited}

Abbott, P.L., and Woodruff, C.M., Jr., 1986, eds., The Balcones escarpment - Geology, hydrology, ecology and social development in central Texas: Geological Society of America.

Anderson, M.P., and Woessner, W.W., 1992, Applied groundwater modeling - Simulation of flow and advective transport: San Diego, California, Academic Press, Inc., 381 p.

Barker, R.A., and Ardis, A.F., 1996, Hydrogeologic framework of the Edwards-Trinity aquifer system, west-central Texas: U.S. Geological Survey Professional Paper 1421-B, 61 p.

Blondes, M.S., Gans, K.D., Thordsen, J.J., Reidy, M.E., Thomas, B., Engle, M.A., Kharaka, Y.K., and Rowan, E.L., 2013, U.S. Geological Survey National Produced Waters Geochemical Database v. 2.1 (provisional): accessed on April 9, 2013, at http://energy.usgs.gov/EnvironmentalAspects/EnvironmentalAspectsofEnergyProductionandUse/ ProducedWaters.aspx\#3822349-data.

Box, G.E.P., and Draper, N.R., 1987, Empirical modelbuilding and response surfaces: Oxford, England, John Wiley \& Sons, p. 424.

Collins, E.W., and Hovorka, S.D., 1997, Structure map of the San Antonio segment of the Edwards aquifer and Balcones fault zone, south-central Texas-Structural framework of a major limestone aquifer-Kinney, Uvalde, Medina, Bexar, Comal and Hays Counties: Austin, University of Texas, Bureau of Economic Geology Miscellaneous Map 38.

Crain, E.R., 2013, Crain's petrophysical handbook: accessed on May 23, 2013, at http://www.spec2000.net/01-index.htm.

Dausman, A.M., Doherty, J.E., Langevin, C.D., and Dixon, Joann, 2010a, Hypothesis testing of buoyant plume migration using a highly parameterized variable-density groundwater model at a site in Florida, USA: Hydrogeology Journal, v. 18, no. 1, p. 147-160. 
Dausman, A.M., Doherty, J.E., Langevin, C.D., and Sukop, M.C., 2010b, Quantifying data worth toward reducing predictive uncertainty: Groundwater, v. 48, no. 5, p. 729-740.

Deike, R.G., 1990, Dolomite dissolution rates and possible Holocene dedolomitization of water-bearing units in the Edwards aquifer, south-central Texas: Journal of Hydrology, v. 112 , p. 335-373.

Doherty, J.E., 2003, Groundwater model calibration using pilot points and regularization: Groundwater, v. 41, no. 2 , p. 170-177, accessed January 13, 2015, at http://info.ngwa. org/gwol/pdf/031075995.pdf?origin=publication_detail.

Doherty, J.E., 2005, PEST-Model-independent parameter estimation user manual (5th ed.): Brisbane, Australia, Watermark Numerical Computing, $336 \mathrm{p}$.

Doherty, J.E., 2011, PEST groundwater data utilities, Part AOverview: Watermark Numerical Computing, 68 p.

Doherty, J.E., 2015, Calibration and uncertainty analysis for complex environmental models-PEST: Complete theory and what it means for modelling the real world: Brisbane, Australia, Watermark Numerical Computing, 236 p.

Doherty, J.E., and Hunt, R.J., 2010, Approaches to highly parameterized inversion-A guide to using PEST for groundwater-model calibration: U.S. Geological Survey Scientific Investigations Report 2010-5169, 59 p.

Doherty, J.E., and Welter, D.E., 2010, A short exploration of structural noise: Water Resources Research, v. 46, no. 5, $14 \mathrm{p}$.

Doherty, J.E., Fienen, M.N., and Hunt, R.J., 2010a, Approaches to highly parameterized inversion-Pilot-point theory, guidelines, and research directions: U.S. Geological Survey Scientific Investigations Report 2010-5168, 36 p.

Doherty, J.E., Hunt, R.J., and Tonkin, M.J., 2010b, Approaches to highly parameterized inversion-A guide to using PEST for model-parameter and predictive-uncertainty analysis: U.S. Geological Survey Scientific Investigations Report 2010-5211, 71 p.

Edwards Aquifer Authority, 2015, Bexar index well (J-17) historic data: accessed February 3, 2015, at http://www. edwardsaquifer.org/aquifer-data-and-maps/historical-data/ historic-data-downloads.

Esri, 2015a, ArcGIS Desktop-Release 10: Redlands, Calif. [Also available at http://www.esri.com.]

Esri, 2015b, Natural neighbor (spatial analyst): accessed February 9, 2015, at http://help.arcgis.com/en/arcgisdesktop/10.0/help/index.html\#//009z0000006p000000.htm.

Evenick, J.C., 2008, Introduction to well logs and subsurface maps: Tulsa, Oklahoma, PennWell Corporation, 236 p.
Fetter, C.W., 1999, Contaminant hydrogeology (2d ed.): Long Grove, Illinois, Waveland Press, Inc., 500 p.

Fienen, M.N., D’Oria, Marco, Doherty, J.E., and Hunt, R.J., 2013, Approaches in highly parameterized inversionbgaPEST, a Bayesian geostatistical approach implementation with PEST - Documentation and instructions: U.S. Geological Survey Techniques and Methods, book 7 , chapter $\mathrm{C} 9,86 \mathrm{p}$.

Fienen, M.N., Doherty, J.E., Hunt, R.J., and Reeves, H.W., 2010, Using prediction uncertainty analysis to design hydrologic monitoring networks-Example applications from the Great Lakes water availability pilot project: U.S. Geological Survey Scientific Investigations Report 2010-5159, 44 p.

Franke, O.L., Reilly, T.E., and Bennett, G.D., 1987, Definition of boundary and initial conditions in the analysis of saturated ground-water flow systems-An introduction: Techniques of Water-Resources Investigations of the United States Geological Survey, book 3, chapter B5, 15 p.

Freeze, R.A., and Cherry, J.A., 1979, Groundwater: Englewood Cliffs, New Jersey, Prentice-Hall, 604 p.

Garza, Sergio, 1962, Chemical analyses of water from observation wells in the Edwards and associated limestones, San Antonio area, Texas: San Antonio, Tex., Edwards Underground Water District Bulletin, $56 \mathrm{p}$.

Garza, Sergio, 1966, Ground-water resources of the San Antonio area, Texas-A progress report on studies, 1960-64: Texas Water Development Board Report 34, 36 p.

Gelman, Andrew, Carlin, J.B., Stern, H.S., Dunson, D.B., Vehtari, Aki, and Rubin, D.B., 2014, Bayesian data analysis ( $3 \mathrm{~d}$ ed.): London, CRC Press, Taylor and Francis Group, $675 \mathrm{p}$.

Groschen, G.E., 1994, Analysis of data from test-well sites along the downdip limit of freshwater in the Edwards aquifer, San Antonio, Texas, 1985-87: U.S. Geological Survey Water-Resources Investigations Report 93-4100, 92 p.

Groschen, G.E., and Buszka, P.M., 1997, Hydrogeologic framework and geochemistry of the Edwards aquifer salinewater zone, south-central Texas: U.S. Geological Survey Water-Resources Investigations Report 97-4133, 47 p.

Guo, Weixing, and Langevin, C.D., 2002, User's guide to SEAWAT - A computer program for simulation of threedimensional variable-density ground-water flow: Techniques of Water-Resources Investigations of the United States Geological Survey, book 6, chap. A7, 77 p. [Supersedes U.S. Geological Survey Open-File Report 01-434.]

Harbaugh, A.W., 2005, MODFLOW-2005, the U.S. Geological Survey modular ground-water model-The groundwater flow process: U.S. Geological Survey Techniques and Methods, book 6, chap. A16, [variously paged]. 
Harbaugh, A.W., Banta, E.R., Hill, M.C., and McDonald, M.G., 2000, MODFLOW-2000, the U.S. Geological Survey modular ground-water model-User guide to modularization concepts and the ground-water flow process: U.S. Geological Survey Open-File Report 00-92, 121 p.

Hill, M.C., and Tiedeman, C.R., 2007, Effective groundwater model calibration - with analysis of data, sensitivities, predictions, and uncertainty: Hoboken, New Jersey, John Wiley \& Sons, Inc., 455 p.

Hovorka, S.D., Dutton, A.R., Ruppel, S.C., and Yeh, J.S., 1996, Edwards aquifer ground-water resources-Geologic controls on porosity development in platform carbonates, South Texas: Austin, The University of Texas, Bureaus of Economic Geology Report of Investigations 238, 75 p.

Hovorka, S.D., Mace, R.E., and Collins, E.W., 1998, Permeability structure of the Edwards aquifer, south Texas-Implications for aquifer management: Austin, The University of Texas, Bureau of Economic Geology Report of Investigations $250,55 \mathrm{p}$.

Hovorka, S.D., Ruppel, S.C., Dutton, A.R., and Yeh, J.S., 1993, Edwards aquifer storage assessment, Kinney County to Hays County, Texas: Austin, Texas, The University of Texas, Bureau of Economic Geology, 115 p.

Isaaks, E.H., and Srivastava, R.M., 1989, An introduction to applied geostatistics: New York, Oxford University Press, $561 \mathrm{p}$

Klemt, W.B., Knowles, T.R., Edler, G.R., and Sieh, T.W., 1979, Ground-water resources and model applications for the Edwards (Balcones fault zone) aquifer in the San Antonio region: Texas Water Development Board Report 239, $88 \mathrm{p}$.

Konikow, L.F., and Bredehoeft, J.D., 1992, Ground-water models cannot be validated: Advances in Water Resources, v. 15 , p. $75-83$.

Kuniansky, E.L., Fahlquist, Lynne, and Ardis, A.F., 2001, Travel times along selected flow paths of the Edwards Aquifer, Central Texas, in Kuniansky, E.L., U.S. Geological Survey Karst Interest Group_-Proceedings, St. Petersburg, Florida, February 13-16, 2001: U.S. Geological Survey Water-Resources Investigations Report 2001-4011, p. 69-77.

Lambert, R.B., Hunt, A.G., Stanton, G.P., and Nyman, M.B., 2009, Water-level, borehole geophysical log, and waterquality data from wells transecting the freshwater/salinewater interface of the San Antonio segment of the Edwards aquifer, south-central Texas, 1999-2007: U.S. Geological Survey Data Series 403, [variously paged]. [Also available at http://pubs.usgs.gov/ds/403/.]
Lambert, R.B., Hunt, A.G., Stanton, G.P., and Nyman, M.B., 2010, Lithologic and physicochemical properties and hydraulics of flow in and near the freshwater/saline-water transition zone, San Antonio segment of the Edwards aquifer, south-central Texas, based on water-level and borehole geophysical log data, 1999-2007: U.S. Geological Survey Scientific Investigations Report 2010-5122, 69 p.

Langevin, C.D., 2000, Simulation of ground-water discharge to Biscayne Bay, southeastern Florida: U.S. Geological Survey Water-Resources Investigations Report 2000-4251, $127 \mathrm{p}$.

Langevin, C.D., Shoemaker, W.B., and Guo, Weixing, 2003, MODFLOW-2000, the U.S. Geological Survey Modular Ground-Water Model-Documentation of the SEAWAT-2000 version with the Variable-Density Flow Process (VDF) and the Integrated MT3DMS Transport Process (IMT): U.S. Geological Survey Open-File Report 03-426, $43 \mathrm{p}$.

Langevin, C.D., Thorne, D.T., Jr., Dausman, A.M., Sukop, M.C., and Guo, Weixing, 2008, SEAWAT Version 4-A computer program for simulation of multi-species solute and heat transport: U.S. Geological Survey Techniques and Methods, book 6, chap. A22, 39 p.

Larkin, T.J., and Bomar, G.W., 1983, Climatic atlas of Texas: Austin, Texas Department of Water Resources, LP-192, p. 157, accessed January 12, 2015, at http://www.twdb.state. tx.us/publications/reports/limited_printing/doc/LP192.pdf.

LBG-Guyton Associates, 1995, Edwards aquifer ground-water divides assessment, San Antonio region, Texas: San Antonio, Edwards Underground Water District Report 95-01, $35 \mathrm{p}$.

Lindgren, R.J., 2006, Diffuse-flow conceptualization and simulation of the Edwards aquifer, San Antonio region, Texas: U.S. Geological Survey Scientific Investigations Report 2006-5319, 48 p.

Lindgren, R.J., Dutton, A.R., Hovorka, S.D., Worthington, S.R.H., and Painter, Scott, 2004, Conceptualization and simulation of the Edwards aquifer, San Antonio region, Texas: U.S. Geological Survey Scientific Investigations Report 2004-5277, 143 p.

Lindgren, R.J., Houston, N.A., Musgrove, M., Fahlquist, L.S., and Kauffman, L.J., 2011a, Simulations of groundwater flow and particle-tracking analysis in the zone of contribution to a public-supply well in San Antonio, Texas: U.S. Geological Survey Scientific Investigations Report 20115149, 93 p. 
Lindgren, R.J., Houston, N.A., Musgrove, M., Fahlquist, L.S., and Kauffman, L.J., 2011b, Hydrogeologic setting and groundwater-flow simulations of the South-Central Texas regional study area, Texas, section 3 of Eberts, Sandra M., ed., Hydrogeologic settings and groundwater-flow simulations for regional investigations of the transport of anthropogenic and natural contaminants to public-supply wellsInvestigations begun in 2004: U.S. Geological Survey Professional Paper 1737-B, p. 3-1-3-51.

Lindgren, R.J., Taylor, C.J., and Houston, N.A., 2009, Description and evaluation of numerical groundwater flow models for the Edwards aquifer, south-central Texas: U.S. Geological Survey Scientific Investigations Report 2009$5183,25 \mathrm{p}$.

Lozo, F.E., Jr., and Smith, C.I., 1964, Revision of Comanche Cretaceous stratigraphic nomenclature, southern Edwards Plateau, southwest Texas: Gulf Coast Association of Geological Societies Transactions, v. 14, p. 285-306.

Maclay, R.W., 1995, Geology and hydrology of the Edwards aquifer in the San Antonio area, Texas: U.S. Geological Survey Water-Resources Investigation Report 95-4186, 64 p.

Maclay, R.W., and Land, L.F., 1988, Simulation of flow in the Edwards aquifer, San Antonio region, Texas and refinements of storage and flow concepts: U.S. Geological Survey Water-Supply Paper 2336-A, 48 p.

Maclay, R.W., and Small, T.A., 1984, Carbonate geology and hydrology of the Edwards aquifer in the San Antonio area, Texas: U.S. Geological Survey Open-File Report 83-537, $72 \mathrm{p}$.

Meyer, C.D., 2000, Matrix analysis and applied linear algebra: Philadelphia, Pennsylvania, Society for Industrial and Applied Mathematics, $718 \mathrm{p}$.

Miller, L.D., and Long, A.J., 2006, Statistical analyses of hydrologic system components and simulation of Edwards aquifer water-level response to rainfall using transfer-function models, San Antonio region, Texas: U.S. Geological Survey Scientific Investigations Report 2006-5131, 20 p. [1 appendix, online only].

Moore, Catherine, and Doherty, J.E., 2005, Role of the calibration process in reducing model predictive error: Water Resources Research, v. 41, no. 5, 14 p.

Musgrove, MaryLynn, Fahlquist, Lynne, Houston, N.A., Lindgren, R.J., and Ging, P.B., 2010, Geochemical evolution processes and water-quality observations based on results of the National Water-Quality Assessment Program in the San Antonio segment of the Edwards aquifer, 1996-2006: U.S. Geological Survey Scientific Investigations Report 2010-5129, 93 p.
Oetting, G.C., Banner, J.L., and Sharp, J.M., Jr., 1996, Regional controls on the geochemical evolution of saline groundwaters in the Edwards aquifer, central Texas: Journal of Hydrology, v. 181, p. 251-283.

Oliver, D.S., Reynolds, A.C., and Liu, Ning, 2008, Inverse theory for petroleum reservoir characterization and history matching: New York, Cambridge University Press, 380 p.

Painter, Scott, Jiang, Yefang, and Woodbury, Allan, 2002, Edwards aquifer parameter estimation project final report: Southwest Research Institute [variously paged].

Pavlicek, Diane, Small, T.A., and Rettman, P.L., 1987, Hydrogeologic data from a study of the freshwater zone/salinewater zone interface in the Edwards aquifer, San Antonio region, Texas: U.S. Geological Survey Open-File Report 87-389, $108 \mathrm{p}$.

Perez, Roberto, 1986, Potential for updip movement of saline water in the Edwards aquifer, San Antonio, Texas: U.S. Geological Survey Water-Resources Investigations Report 86-4032, $21 \mathrm{p}$.

Puente, Celso, 1978, Method of estimating natural recharge to the Edwards aquifer in the San Antonio area, Texas: U.S. Geological Survey Water-Resources Investigations Report 78-10, 34 p.

Railroad Commission of Texas, 2012, Online research queries-Imaged records: accessed August 22, 2012, at http:// www.rrc.state.tx.us/about-us/resource-center/research/ online-research-queries/about-imaged-records/.

Refsgaard, J.C., van der Sluijs, J.P., Højberg, A.L., and Vanrolleghem, P.A., 2007, Uncertainty in the environmental modelling process - A framework and guidance: Environmental Modelling \& Software, v. 22, p. 1543-1556.

Rose, P.R., 1972, Edwards Group, surface and subsurface, central Texas: Austin, The University of Texas, Bureau of Economic Geology Report of Investigations 74, 198 p.

San Antonio Water System, 2012, Water statistics, year ending December 31, 2012: Infrastructure Planning Department, San Antonio Water System, accessed December 22, 2014, at http://www.saws.org/your_water/aquifer/docs/2012_StatsBook.pdf.

Schlumberger, 2015, Oilfield glossary: accessed February 17, 2015, at http://glossary.oilfield.slb.com/.

Schultz, A.L., 1992, Using geophysical logs in the Edwards aquifer to estimate water quality along the freshwater/ saline-water interface (Uvalde to San Antonio, Texas): Edwards Underground Water District Report 92-03, 47 p. 
Schultz, A.L., 1993, Defining the Edwards aquifer freshwater/ saline-water interface with geophysical logs and measured data (San Antonio to Kyle, Texas): Edwards Underground Water District Report 93-06, 81 p.

Schultz, A.L., 1994, Review and update of the position of the Edwards aquifer freshwater/saline-water interface from Uvalde to Kyle, Texas: Edwards Underground Water District Report 94-05, $31 \mathrm{p}$.

Slattery, R.N., 2004, Recharge to the Edwards aquifer in the San Antonio area, Texas, 2003: accessed July 12, 2004, at http://tx.usgs.gov/reports/dist/dist-2004-01.

Texas Commission on Environmental Quality, 2013, Public drinking water, subchapter $\mathrm{F}$-Drinking water standards governing drinking water quality and reporting requirements for public water systems, summary of secondary standards, chap. 290, section 105, accessed January 14, 2015, at http://www.tceq.state.tx.us/assets/public/legal/ rules/rules/pdflib/290f.pdf.

Texas Water Development Board, 2004, Historical water-use information: accessed May 29, 2015, at https://www.twdb. texas.gov/waterplanning/waterusesurvey/estimates/.

Texas Water Development Board, 2013, Groundwater database: accessed August 14, 2013 at http://www.twdb.texas. gov/groundwater/data/Database\%20in\%20ASCII/All\%20 Counties/gwdb.zip.

Texas Water Development Board, 2014, Water data for Texas-Drought in Texas: accessed October 29, 2014, at http://waterdatafortexas.org/drought/.

Thomas, J.V., Stanton, G.P., and Lambert, R.B., 2012, Borehole geophysical, fluid, and hydraulic properties within and surrounding the freshwater/saline-water transition zone, San Antonio segment of the Edwards aquifer, south-central Texas, 2010-11: U.S. Geological Survey Scientific Investigations Report 2012-5285, 65 p., 3 apps.

Thorkildsen, D.F., and McElhaney, P.D., 1992, Model refinement and applications for the Edwards (Balcones fault zone) aquifer in the San Antonio region, Texas: Texas Water Development Board Report 340, 33 p.

U.S. Census Bureau, 2014, Annual estimates of the resident population for incorporated places of 50,000 or more, ranked by July 1, 2013 population, April 1, 2010 to July 1, 2013: U.S. Census Bureau, Population Division, accessed February 18, 2015, at http://factfinder.census.gov/faces/ tableservices/jsf/pages/productview.xhtml?pid=PEP_2013 PEPANNRSIP.US12A\&prodType=table.

U.S. Environmental Protection Agency, 1975, Edwards underground reservoir-Notice of determination: Federal Register, v. 40, no. 242, p. 58344-58345.
U.S. Environmental Protection Agency, 1988, A portion of the Austin-area Edwards aquifer in parts of Hays and Travis Counties, Texas-Sole source aquifer, final determination: Federal Register, v. 53, no. 109, p. 20897-20899.

U.S. Environmental Protection Agency, 2015, Sole source aquifers: accessed February 18, 2015, at http://www.epa. gov/region6/water/swp/ssa/index.htm.

U.S. Geological Survey, 2013, National Water Information System - Web interface (NWISWeb) data: accessed August 2013 at http://waterdata.usgs.gov/tx/nwis/nwis.

U.S. Geological Survey, 2014, SEAWAT—A computer program for simulation of three-dimensional variable-density groundwater flow and transport: accessed August 6, 2014, at http://water.usgs.gov/ogw/seawat/.

Voss, C.I., 2011a, Editor's message, Groundwater modeling fantasies-Part 1, adrift in the details: Hydrogeology Journal, v. 19, no. 7, p. 1281-1284.

Voss, C.I., 2011b, Editor's message, Groundwater modeling fantasies - Part 2, down to earth: Hydrogeology Journal, v. 19 , no. 8 , p. $1455-1458$.

Waite, L.E., 2008, Edwards (Stuart City) shelf margin of south Texas-New data, new concepts: AAPGDatapages, Search and Discovery Article no. 10177 (2009), accessed on December 9, 2014, at http://www.searchanddiscovery.com/ documents/2009/10177waite/.

Welter, D.E., Doherty, J.E., Hunt, R.J., Muffels, C.T., Tonkin, M.J., and Schreüder, W.A., 2012, Approaches in highly parameterized inversion-PEST++, a Parameter ESTimation code optimized for large environmental models: U.S. Geological Survey Techniques and Methods, book 7, sec. C5, $47 \mathrm{p}$.

White, J.T., Doherty, J.E., and Hughes, J.D., 2014, Quantifying the predictive consequences of model error with linear subspace analysis: Water Resources Research, v. 50, p. 1152-1173.

White, J.T., Welter, D.E., Hunt, R.J., and Doherty, J.E., 2015, Integrating linear-based uncertainty analyses into PEST++, in Maxwell, Reed, Hill, Mary, Zheng, Chunmiao, and Tonkin, Matt, MODFLOW and more 2015: Modeling a complex world—Proceedings, Golden, Colorado, May $31-$ June 3, 2015, 559 p.

Winston, R.B., 2015, Online guide to MODFLOW-2005: accessed February 17, 2015, at http://water.usgs.gov/ogw/ modflow/MODFLOW-2005-Guide/.

Winters, K.E., 2013, A historical perspective on precipitation, drought severity, and streamflow in Texas during 1951-56 and 2011: U.S. Geological Survey Scientific Investigations Report 2013-5113, 24 p. 
Wong, C.I., Kroman, J.S., Hunt, B.B., Smith, B.A., and Banner, J.L., 2013, Investigating groundwater flow between Edwards and Trinity aquifers in Central Texas: Groundwater, v. 52, no. 4, p. 624-639.

Zheng, Chunmiao, and Bennett, G.D., 2002, Applied contaminant transport modeling: New York, Wiley-Interscience, $621 \mathrm{p}$.

Zheng, Chunmiao, and Wang, P.P., 1999, MT3DMS, A modular three-dimensional multi-species transport model for simulation of advection, dispersion and chemical reactions of contaminants in groundwater system-Documentation and user's guide: Vicksburg, Mississippi, U.S. Army Engineer Research and Development Center Contract Report SERDP-99-1, 202 p. 

